\title{
Szilikonolaj nemlineáris viszkoelasztikus tulajdonságainak mérése és modellezése
}

PhD értekezés

Szerző:

Kőkuti Zoltán

Témavezető:

Dr. Czirják Attila

\author{
Fizika Doktori Iskola \\ Müszaki és Anyagtudományi Intézet \\ Szegedi Tudományegyetem \\ Természettudományi és Informatikai Kar
}

2015

Szeged 


\section{Tartalomjegyzék}

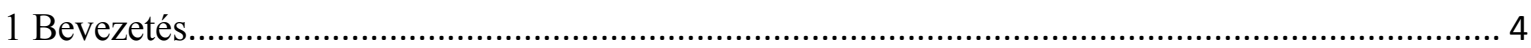

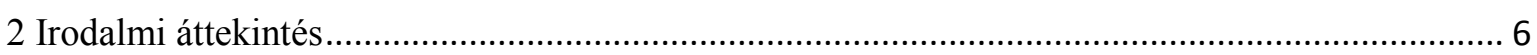

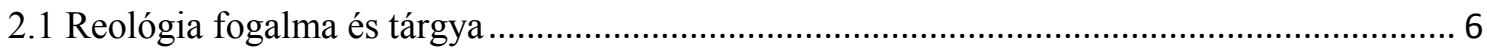

2.2 Folyadékok osztályozása viszkozitás alapján ............................................................ 9

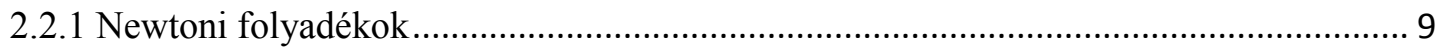

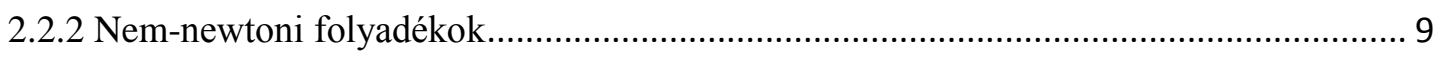

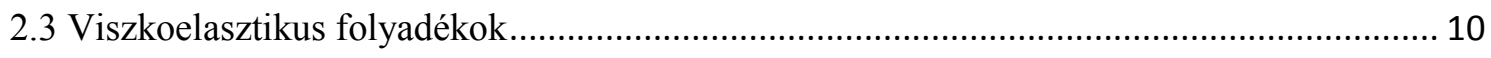

2.3.1 Lineáris viszkoelasztikus folyadékok .................................................................. 12

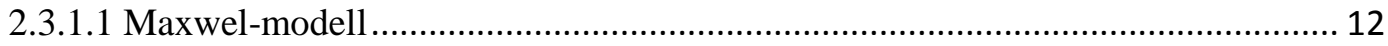

2.3.1.2 Kis amplitúdójú oszcillációs nyírás (SAOS) …………….................................. 14

2.3.1.3 Cox-Merz szabály ...................................................................................... 16

2.3.2 Nemlineáris viszkoelasztikus folyadékok .............................................................. 16

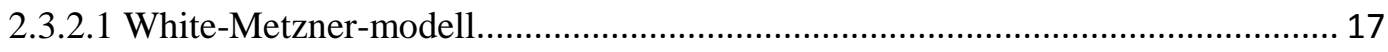

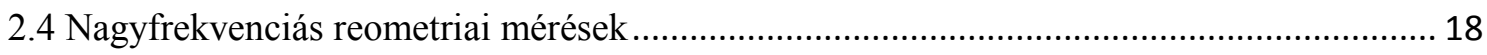

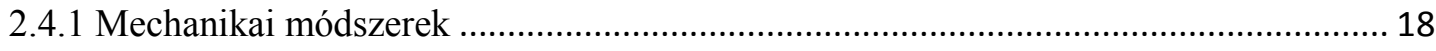

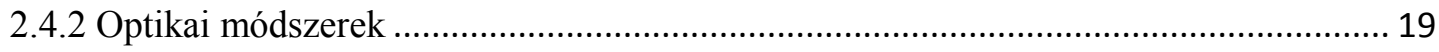

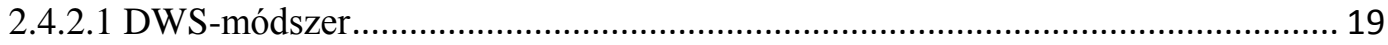

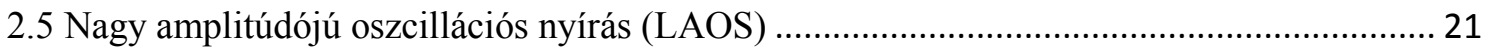

2.5.1. Fourier transzformációs reológia (FTR) …………............................................... 21

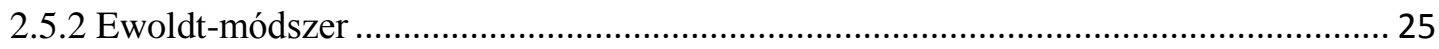

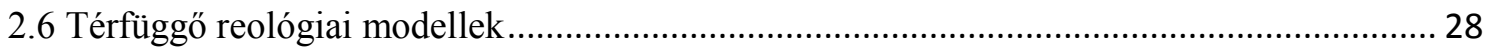

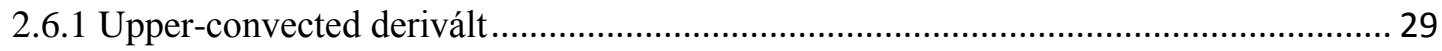

2.6.2 Upper-convected Mawell-modell (UCM-modell) ..................................................... 29

2.6.3 Upper-convected White-Metzner-modell ............................................................ 30

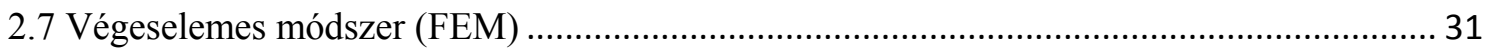




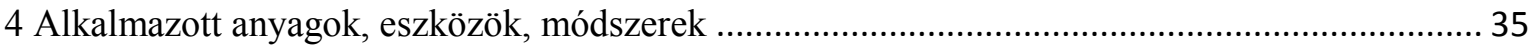

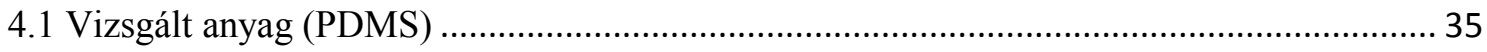

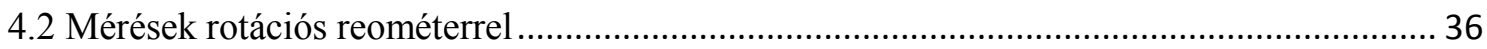

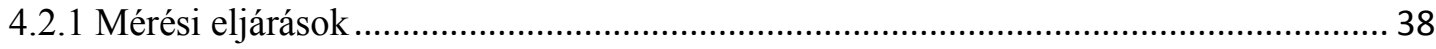

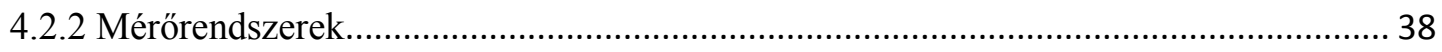

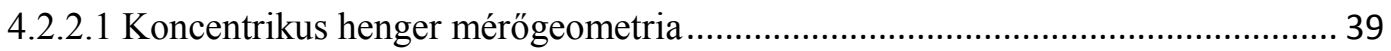

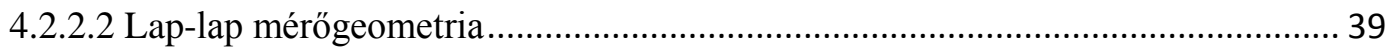

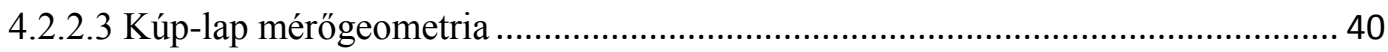

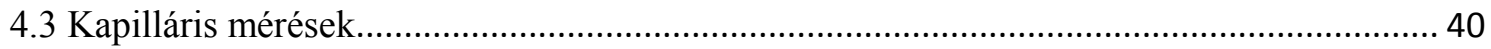

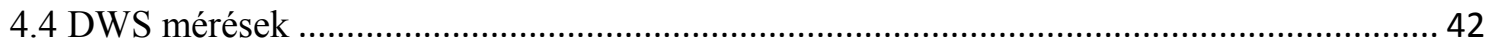

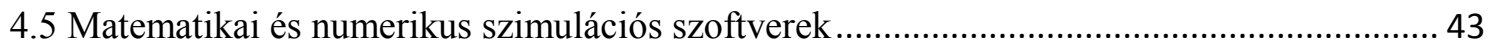

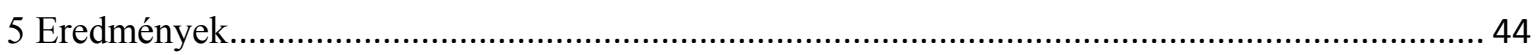

5.1 Szilikonolaj tisztán viszkózus tulajdonságainak vizsgálata ................................................ 44

5.2 Rotációs reométerrel mért lineáris viszkoelasztikus jellemzők .......................................... 46

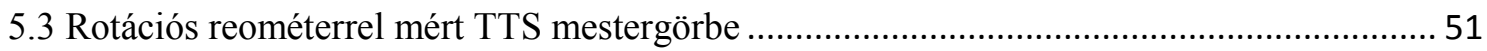

5.4 Cox-Merz szabály érvényessége a rotációs reométerrel mért adatokra ................................ 59

5.5 Nagyfrekvenciás reometria a DWS módszer segítségével................................................. 61

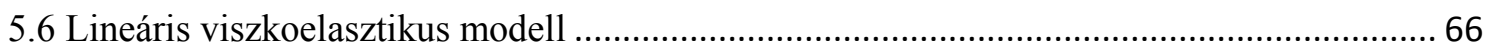

5.7 Nemlinearitás: Pszeudoplasztikus viselkedés és a Cox-Merz szabály ................................. 68

5.8 Nemlineáris, változó súlyozású White-Metzner-modell .................................................. 70

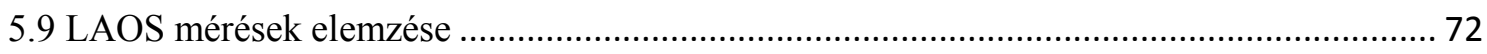

5.10 Térfüggő viszkoelasztikus anyagi egyenlet és tesztelése .............................................. 85

5.10.1 A térfüggő White-Metzner-modell egyenletei ........................................................ 85

5.10.2 CP mérőfej végeselemes szimulációja ............................................................. 87

5.10.3 A CC mérőfej végeselemes szimulációja............................................................. 92 


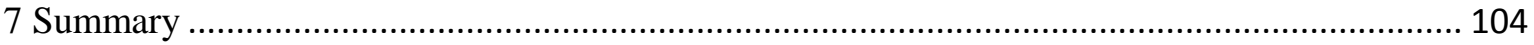

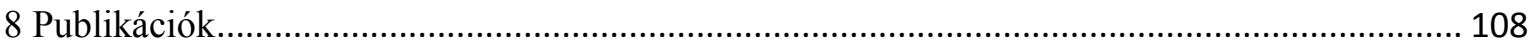

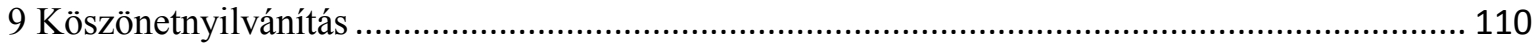

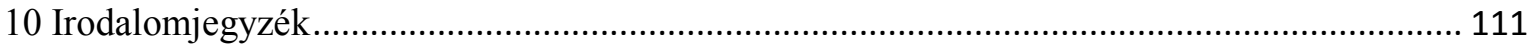




\section{Bevezetés}

A reológia a fluidumok, vagyis gázok, folyadékok és folyadékszerü, lágy anyagok mechanikai deformációjával, illetve folyásával foglalkozik, azok anyagi törvényszerüségeit írja le. A legismertebb reológiai fogalmak a viszkozitás és annak függése a hőmérséklettől vagy a nyírási sebességtől, továbbá a viszkoelasztikus, illetve a plasztikus viselkedés. A reológia tárgykörébe elsősorban olyan anyagok tartoznak, amelyek összetett deformációs tulajdonságokat mutatnak. Utóbbiaknak az anyagszerkezettel való alapvető kapcsolata miatt a reometria, azaz a reológiai jellemzők mérése egyben fontos anyagvizsgálati módszer is. Napjainkban főként a müszaki, anyag-, illetve élettudományokban megjelenő komplex folyadékok vizsgálatának elengedhetetlen eleme a reológia és a reometria, továbbá az élelmiszer-, építő-, gyógyszer-, jármü- és vegyipar fejlődése is mindinkább szükségessé teszi a termékekben és rendszerekben jelen levő fluidumok pontos kontinuummechanikai leírását.

A viszkoelasztikus folyadékok a reológiában tanulmányozott legfontosabb anyagok közé tartoznak. Ezen folyadékok rugalmas tulajdonságait általában hosszú láncmolekulák biztosítják. Nem meglepő tehát, hogy a tipikus viszkoelasztikus folyadék valamely polimer olvadéka vagy oldata. Ha elegendően nagy nyírásnak teszünk ki egy viszkoelasztikus folyadékot, akkor általában nemlineáris anyagi választ kapunk. A nemlineáris válasz viszkoelasztikus mérése és modellezése a modern reológia legbonyolultabb problémái közé tartozik.

A szilikonolajokat (polydimethylsiloxane, PDMS) igen széles körben alkalmazzák az alap és alkalmazott kutatástól kezdve egészen a szerteágazó ipari felhasználásokig. Különleges reológiai viselkedése miatt gyakran használják a polimerkémiában és anyagtudományokban. Előszeretettel alkalmazzák új reológiai elméletek, újszerü mérési eljárások és mérőműszerek hitelesítésére tesztfolyadékként. Egyes reométergyártó vállalatok a készülékek mindenkori kalibráláshoz is bizonyos szilikonolajakat használnak. A jármüipar elsősorban a rezgések és lengések kontrollált csillapítására alkalmazza a szilikonolajokat. Speciális használati területe a dugattyús motorok fötengelyének szabad végén elhelyezkedő torziós viszkózus lengéscsillapító, ahol a szükséges nagy viszkozitást a szilikonolaj biztosítja. Ahhoz, hogy a nagy viszkozitású szilikonolajokat az alapkutatásokban és az ipari alkalmazásokban megfelelően tudjuk felhasználni, 
nélkülözhetetlen, hogy megismerjük az anyag részletes reológiai tulajdonságait, mind a lineáris, mind a nemlineáris viszkoelasztikus tartományban.

Jelen dolgozatban egy nagy viszkozitású szilikonolaj reológiai tulajdonságainak részletes kísérleti vizsgálatát, és a mérési eredményekre alapozott modellezését ismertetem. Az erre a célra mintaként kiválasztott konkrét anyag jól reprezentál egy fontos anyagcsaládot. Kutatómunkám motivációját és ipari hátterét az előző bekezdésben említett jármüipari alkalmazás adta. A szakirodalomban rendkívül kevés megbízható információ állt rendelkezésre az általam vizsgált nagy viszkozitási tartományba eső szilikonolajok reológiájáról, aminek egyik fontos oka az, hogy ezek az anyagok több szempontból is nehezen mérhetőek a tipikus müszerek mérési képességeivel. A saját méréseim során ezért igyekeztem a legmodernebb mérőmüszerekhez is hozzáférni, aminek során sikerült értékes új szakmai kapcsolatokat kialakítanom hazai és külföldi kutatóhelyekkel, ipari partnerekkel. A matematikai modellezés során törekedtem arra, hogy a modell egyenletei a kellően pontos leírás mellett lehetőség szerint szemléletes fizikai tartalommal is bírjanak. Az egyenletek numerikus megoldásához széles körben használatos, a maguk területén standardnak tekinthető szoftvereket alkalmaztam. 


\section{Irodalmi áttekintés}

\subsection{Reológia fogalma és tárgya}

A reológia az erő hatásának kitett anyagok deformációjával és folyásával foglalkozik, az alakváltozást létrehozó feszültség és az anyag alakváltozási tulajdonságai közötti összefüggéseket tanulmányozza. A mechanikai feszültség hatására létrejövő deformációkat több más rokon tudományág (pl. áramlástan, szilárdságtan) is vizsgálja, a reológia elsősorban a folyadékok, és puha szilárd testek folyását írja le, különös tekintettel azokra az anyagokra, ahol a deformáció és a feszültség közötti összefüggés nem írható le egyszerü lineáris függvényekkel. Egy anyag reológiai viselkedésének kísérleti vizsgálatát reometriának [1] nevezzük, előfordul azonban, hogy a reológia kifejezést a reometria szó rokon értelmü megfelelőjeként is használják. Ettől eltérően, a reológia valódi értelemben elsősorban az anyagok deformációjának, és a deformációt létrehozó mechanikai feszültség közötti kapcsolatot vizsgálja (makroreológia), valamint az anyag belső szerkezetének ismeretében próbál következtetni az anyag deformációs tulajdonságaira (mikroreológia). A reológia elnevezést Eugene C. Bingham, a Lafayette College professzora adta 1920-ban [2]. Az elnevezést a ,panta rei” („minden folyik”) idézet ihlette, amit tévesen Hérakleitosznak tulajdonítottak (de voltaképpen Szimplikiosz írásaiból való).

Mint ahogy az a kontinuummechanikából ismert, egy folyadék áramlási képe $\underline{\mathrm{v}}(x, y, z, t)$ meghatározható az 1. ábrán szereplő egyenletek megoldásával. Az egyenletek megoldásához azonban szükséges az anyagra jellemző úgynevezett konstitúciós egyenlet ismerete. A reológia legfőbb feladata ezen anyagi egyenlet meghatározása. Ebből következően a reológia a klasszikus kontinuummechanika egyik ágának is tekinthető, amelynek legfontosabb feladata az anyagban ébredő mechanikai feszültségek és a hatásukra létrejövő deformációk közötti összefüggések feltárása, azaz a konstitúciós egyenlet(ek) megadása. 


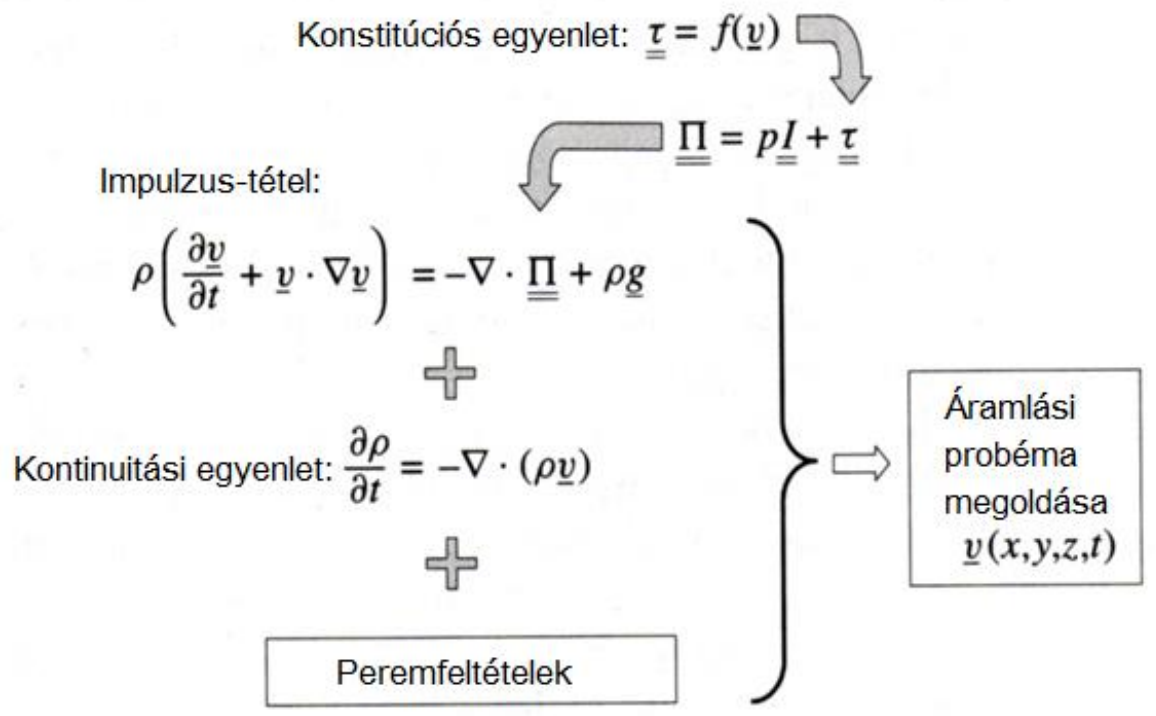

1.ábra: A folyadékok áramlási képének meghatározásához szükséges differenciálegyenletek rendszerező ábrája

A reológia egyszerü deformációk alapján határozza meg a komplex anyagokra jellemző konstitúciós egyenleteket. Ilyen egyszerü deformációk a nyírási és nyúlási vizsgálatok. A cél olyan mérési eljárások kialakítása, amelyeknél jó közelítéssel homogén és lamináris áramlási kép alakul ki, valamint az, hogy a bonyolult kapcsolt vektor és tenzoregyenletek helyett egyszerübb koncentrált paraméterü egyenleteket alkalmazhassunk.

Jelen dolgozat tárgyát az anyag nyírási tulajdonságai képezik, ezért a továbbiakban egy ilyen egyszerüsített áramlási kép alapján mutatom be részletesen a reológiai alapmennyiségeket, az alap konstitúciós egyenleteket és a mérési alapeljárásokat. A bonyolultabb vektor- és tenzoregyenletekkel a FEM szimulációs témakörben foglalkozom részletesebben. A legegyszerübb elrendezés az úgynevezett lap-lap modell (two plates model): Tegyük fel, hogy a minta két párhuzamos lap között helyezkedik el, a lap alapterülete $A$, a folyadék magassága $h$. Nyírjuk meg a folyadékot (fejtsünk ki $\underline{F}$ erőt a téglatest felső lapjára, miközben az alsó lapot rögzítjük). A lap-lap modell vázlata a 2. ábrán látható. 


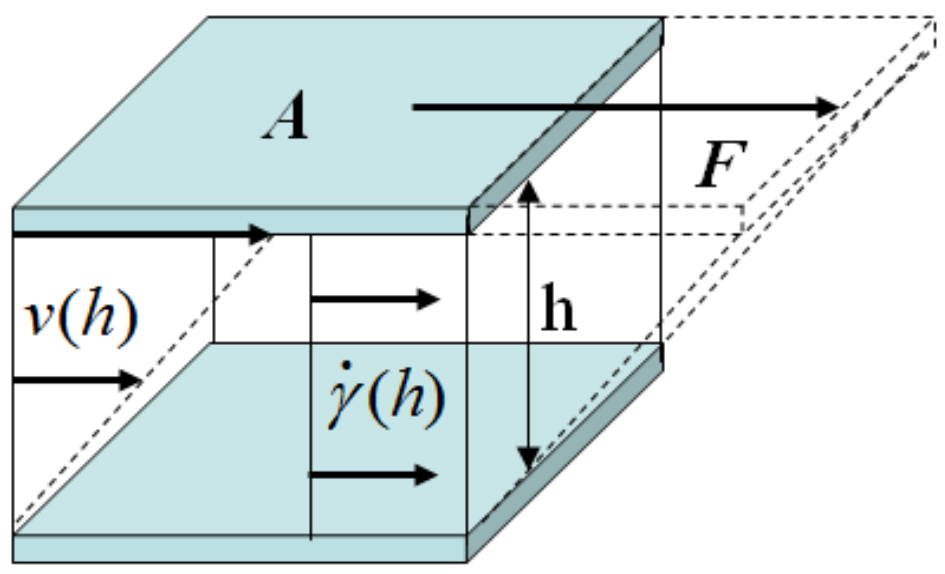

2. ábra: A lap-lap modell vázlata

A reológiában leggyakrabban használt két alapmennyiség a nyírási sebesség, amely a rétegek elmozdulásával kapcsolatos, valamint a nyírófeszültség, amely az adott nyírási sebesség létrejöttét határozza meg [3]. A lap-lap modellben a nyírási sebesség (sebességgradiens) a következőképp adható meg:

$$
\dot{\gamma}(t)=\frac{\partial v(h, t)}{\partial h}=\frac{\partial \gamma(t)}{\partial t} \quad\left[\frac{1}{s}=s^{-1}\right],
$$

ahol $\frac{\partial v(h, t)}{\partial h}$ a sebesség gradiens. A nyírási sebességet megkaphatjuk a nyírás időderiváltja $\frac{\partial \gamma(t)}{\partial t}$ szerint is.

A nyírófeszülltség pedig az egységnyi felületelemre eső a folyadékban kialakuló nyíróerő nagysága:

$$
\sigma(t)=-\frac{F(t)}{A} \quad\left[\frac{N}{m^{2}}=P a\right]
$$

A nyírófeszültség és nyírási sebesség közti összefüggést

$$
\sigma(t)=f(\dot{\gamma}(T))
$$

konstitutív (anyagi) egyenletnek nevezzük. A nyírófeszültség értékét az adott időpillanatban $(t)$ nemcsak az ebben a pillanatban érvényes nyírási sebesség értéke, hanem a korábbi nyírási sebességek értékei is befolyásolhatják $(T \leq t)$. 


\subsection{Folyadékok osztályozása viszkozitás alapján}

Amennyiben a konstitutív egyenletben szereplő nyírófeszültség csak az adott időpillanatbeli nyírási sebességtől függ, akkor egyszerü folyadékról beszélhetünk, míg ellenkező esetben viszkoelasztikus folyadékokról van szó (2.3 egyenlet). Mindkét folyadéktípus lehet lineáris vagy nemlineáris.

\subsubsection{Newtoni folyadékok}

A viszkozitás értelmezését elsőként Newton adta meg [4], aki feltételezte, hogy a rétegek párhuzamos és egyenletes áramlása esetén az elmozdulás irányával ellentétes irányú nyíróerő egyenesen arányos a felületek nagyságával, és a nyírási sebességgel (sebesség-gradienssel). Az arányossági tényező az adott gáz vagy folyadék anyagi minőségére jellemző állandó, a dinamikai viszkozitás $(\eta)$ :

$$
\sigma(t)=-\eta \cdot \dot{\gamma}_{D}(t)
$$

Más megfogalmazásban a Newton-féle viszkozitási törvény kimondja, hogy az egyes rétegek közötti nyírófeszültség egyenesen arányos a sebesség-gradienssel (viszkozitása állandó). Több folyadék, mint például a víz, egyes olajok, glicerin kielégítik Newton feltételét, ezeket newtoni folyadékoknak nevezzük.

\subsubsection{Nem-newtoni folyadékok}

Minden olyan folyadékot, amelynek nyírófeszültsége nem egyenesen arányos a nyírási sebességgel (viszkozitása nem állandó), a nem-newtoni folyadékok csoportjába sorolunk. Ezen belül két fö részre oszthatjuk a folyadékokat. Vannak az úgynevezett dilatáló folyadékok, amelyek viszkozitása nő, ha növeljük a nyírási sebességet, ezeket angolul shear thickening folyadéknak nevezzük. Ilyenek például a keményítő szörp vagy egyes lakkok. A másik csoportot a pszeudoplasztikus (shear thinning) folyadékok alkotják, amelyek viszkozitása csökken, ha növeljük a nyírási sebességet. Ilyen például a paradicsompüré, a majonéz, a vér. A 3. ábra a különböző típusú folyadékok nyírófeszültségének alakulását mutatja különböző nyírási sebességeknél. Az anyagok tisztán viszkózus viselkedésére legegyszerübben az egyszerű nyírási tesztek (Simple Shear Test) eredményeiböl következtethetünk. Ennek részletesebb bemutatását az anyagok és módszerek fejezetpontban adjuk meg. 

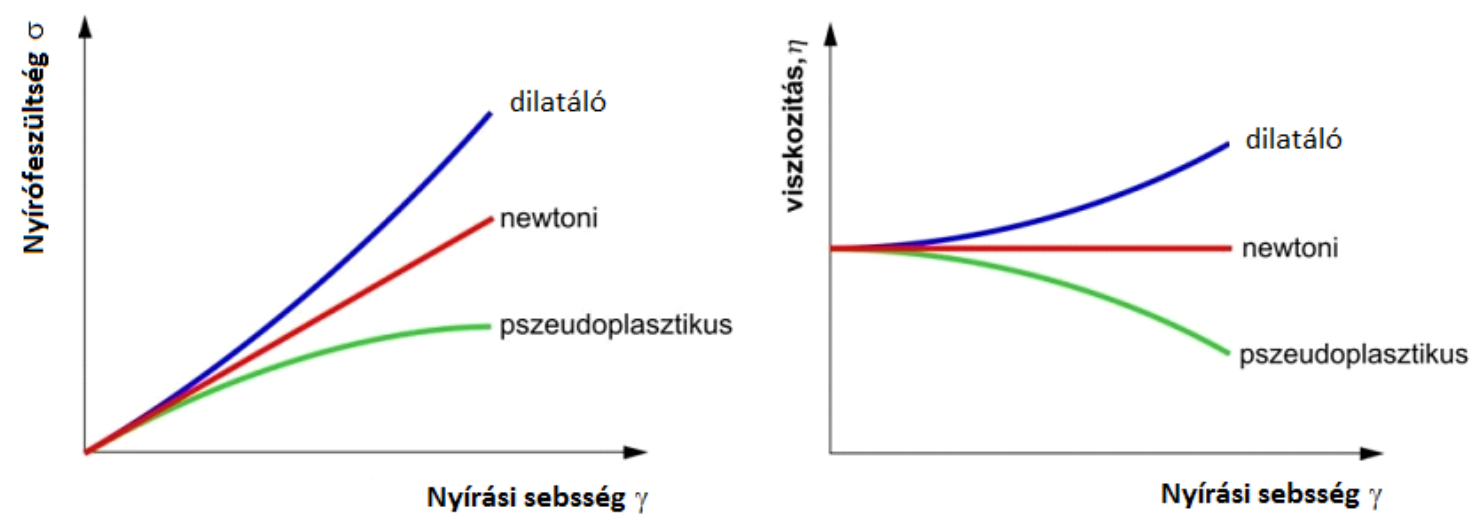

3. ábra: Különböző típusú folyadékok nyírófeszültség (viszkozitás)-nyírási sebesség görbéi

\subsection{Viszkoelasztikus folyadékok}

A nem-newtoni folyadékok jelentős része a viszkoelasztikus folyadékok csoportjába tartozik. Többek között a polimerek oldata vagy olvadéka, aszfalt és az emberi szervezetben jelenlévő folyadékok többsége is ebbe a csoportba tartozik. A viszkoelasztikus folyadékokat az jellemzi, hogy a - fentiekben rendszerezett - viszkózus tulajdonság mellett rugalmas viselkedést is mutatnak. A rugalmas tulajdonság általában folyadékban található hosszú láncmolekuláknak a következménye. Ezek a folyadékok számos különleges tulajdonsággal bírnak, az alábbiakban részletesebben is bemutatom a fontosabbakat.

Az egyik, és talán a legszembetünőbb a Weissenberg-effektus (Weissenberg effect) [6]: Ha egy viszkoelasztikus folyadékba egy a tengelye körül forgó rudat merítünk, akkor a folyadék elkezd felkúszni a keverőrúdra. Ez azzal magyarázható, hogy a viszkoelasztikus folyadékoknál egy, a nyírásra merőleges olyan erő is hat, amely felfelé mozdítja el az anyagi részecskéket. Ezt az érdekes effektust szemlélteti a 4. ábra. 


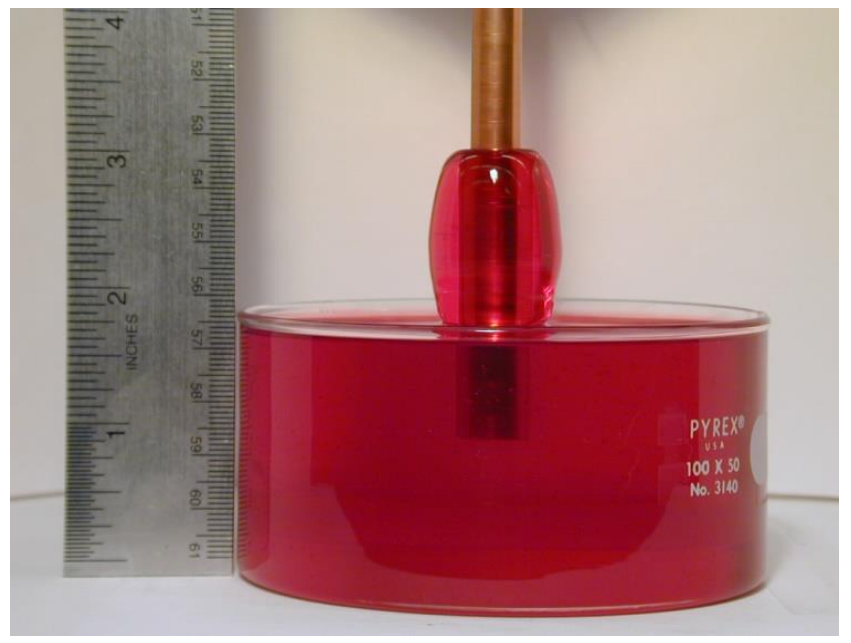

4. ábra: Weissenberg-effektus

Egy másik szembetűnő jelenség az úgynevezett „lélegzés” (Die swell). Ez annyit jelent, hogyha a viszkoelasztikus folyadék egy csőből kiáramlik, akkor a kifolyás után jelentős mértékben megduzzad, majd újra összehúzódik. A kiszélesedés oka az, hogy a csőben áramló viszkoelasztikus folyadék nyíródik, így a cső falát szétfeszíteni igyekszik, tehát a falra egy merőleges nyomóerő is hat, ami a cső megszünése után kitágítja a folyadékot $[7,8]$. Az összehúzódás pedig a nyírás megszünésének a következménye. Ezt az effektust szemlélteti az 5. ábra, amelyen jól látszik az, hogy lényegesen kiszélesedik a folyadék, miután elhagyja csövet.

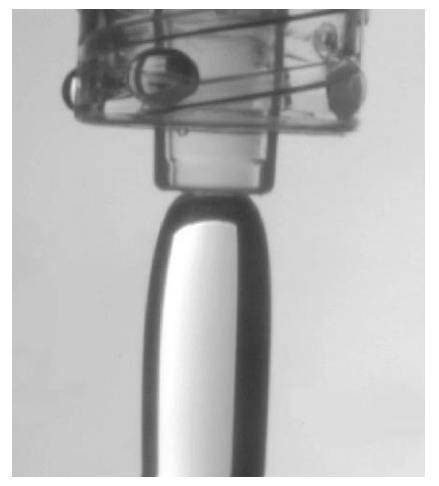

5. ábra: Lélegzés

Az utolsó érdekesség, amit bemutok, az úgynevezett nyitott szívócső-effektus (open siphon effect). Míg newtoni folyadékoknál a szívócsőnek mindig a folyadékban kell lennie ahhoz, hogy a folyadékáramlás folytonos maradjon, addig viszkoelasztikus folyadékoknál csak kezdetben kell a szívócsőnek a folyadékban lennie, később onnan kivéve a szívás fenntartásával a folyadékáramlás továbbra is folyamatos marad. Az oka pedig az, hogy a megnyúlt rugalmas szálacskák képesek megtartani a folyadékoszlopot. Az effektus a nevét 
onnan kapta, hogy a folyadék egy nyitott szívócsövet alkot a szívás hatására [9]. Erröl a jelenségről készített ábrasorozatot láthatjuk a 6. ábrán.
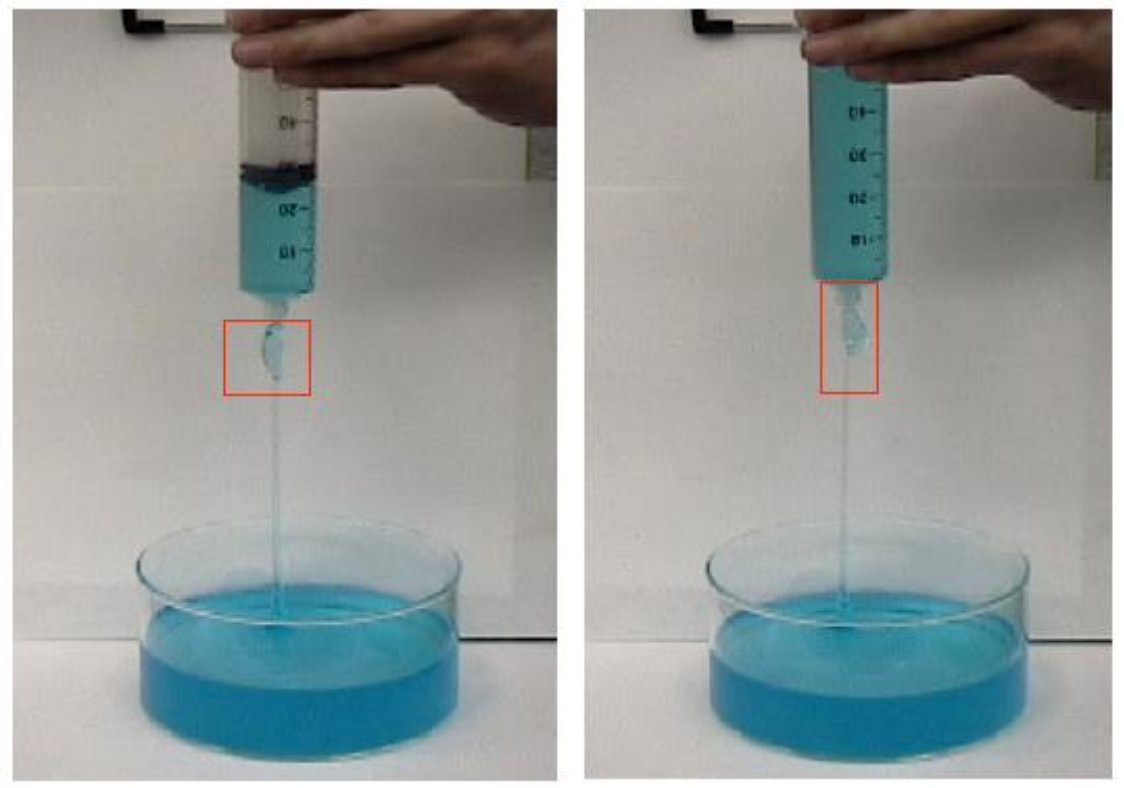

6. ábra: Nyitott szívócső-effektus

A viszkoelasztikus folyadékok két fő részre oszthatók: lineáris, illetve nemlineáris viszkoelasztikus folyadékokra. Először a lineáris viszkoelasztikus folyadékok jellemzését és modellezését mutatom be, majd áttérek a nemlineáris folyadékokra, amelyek jelen dolgozat vizsgálati tárgyát is képezik.

\subsubsection{Lineáris viszkoelasztikus folyadékok}

Egy viszkoelasztikus folyadékot akkor nevezünk lineárisnak, ha az őt leíró viszkózus, illetve rugalmas paraméterek függetlenek a nyírófeszültségtől. Az ilyen típusú folyadékok leírására egy széles körben elterjedt és gyakran alkalmazott modell az úgynevezett Maxwell-modell.

\subsubsection{Maxwel-modell}

A Maxwell-modell [10] alapjául egy egymással sorba kötött Hooke-test (tökéletesen rugalmas) és newtoni test (tökéletesen viszkózus) szolgál. A rendszer lineáris, hiszen mind a Hooke-test, mind a newtoni test paraméterei függetlenek a nyírófeszültségtől (vagy a nyírási sebességtől, illetve a nyírástól). Leggyakrabban az alábbi ábrán (7. ábra) 
látható alakzattal jelölik a Maxwell-testet, ahol egy egymással sorba kötött csillapító tag (damper) és rugó (spring) található.

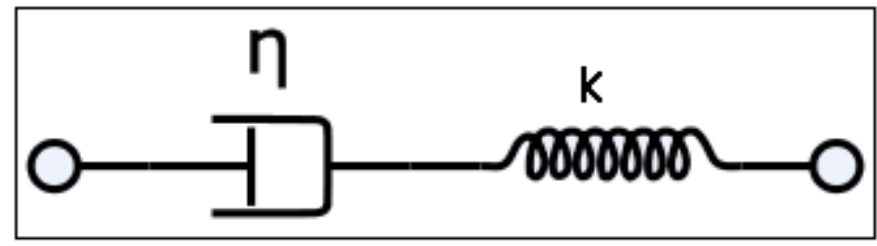

7. ábra: Maxwell-modell

A newtoni testre a Newton-féle viszkozitási törvény érvényes, vagyis a newtoni konstitutív egyenlet (2.4 egyenlet). A Hooke-test esetén pedig a nyírófeszültség egyenesen arányos a deformációval, jelen esetben a nyírással, amely a következő konstitutív egyenlettel írható le [11]:

$$
\sigma(t)=-k \cdot \gamma_{S}(t)
$$

ahol $k$ az arányossági együttható az ún. elasztikus vagy más néven relaxációs modulusz.

A Maxwell-test nyírósebessége egyenlő a testen belül, a nyírási sebessége pedig a viszkózus és az elasztikus tag nyírási sebességének összegével $\left(\dot{\gamma}=\dot{\gamma}_{d}+\dot{\gamma}_{s}\right)$ egyezik meg. Kifejezve a nyírófeszültségeket a 2.4 és 2.5 egyenletekből, a Maxwell-modellt leíró konstitutív egyenlet [12] a következö alakot ölti:

$$
\dot{\gamma}(t)=-\frac{1}{\eta} \cdot \sigma(t)-\frac{1}{k} \dot{\sigma}(t)
$$

Ha a nyírófeszültség független az időtől, akkor az egyenlet a Newton-féle súrlódási törvénybe (2.4 egyenlet) megy át. Pillanatszerü nyírásra viszont kezdetben tökéletesen rugalmas testként (2.5 egyenlet) viselkedik. Az egyetlen rugót és egyetlen csillapítót tartalmazó Maxwell-modellt egyelemű Maxwell-modellnek nevezzük. Sok lineáris viszkoelasztikus folyadék azonban nem jellemezhető egyetlen viszkozitás-, illetve elasztikus modulusz értékkel, az ilyen anyagok több egymással párhuzamosan összekapcsolt Maxwell-testtel jellemezhetők [13]. Elegendően sok Maxwell-elem segítségével bármilyen lineáris viszkoelasztikus folyadék leírható.

Egy tetszőleges lineáris viszkoelasztikus anyag paramétereinek $\left(\eta_{i} ; k_{i}\right)$ meghatározására a frekvencia-pásztázó oszcillációs mérések a legalkalmasabbak. A mérési elvet az anyag és módszerek alfejezetben bővebben is ismertetjük. A nemlineáris viszkoelasztikus folyadékok lineáris viszkoelasztikus tartománybeli viselkedése is 
meghatározható ilyen módon, ha ügyelünk, hogy a méréseket a SAOS (Small Amplitue Oscillatory Shear) tartományban végezzük. A módszer lényege az, hogy megmérjük a folyadék tárolási és veszteségi modulusait a frekvencia függvényében, és a mért görbékre egy $n$ elemü Maxwell-modellt illesztve meghatározzuk a $k_{i}$ elasztikus modulusz(ok) és az $\eta_{i}$ viszkozitás(ok) értékeit. Ezt a módszert tekintem át a következő alfejezetben.

\subsubsection{Kis amplitúdójú oszcillációs nyírás (SAOS)}

Az egyik legszélesebb körben alkalmazott reometriai módszer a kis amplitúdójú oszcillációs nyírási (SAOS, Small Amplitude Oscillatory Shear) teszt. Ebben az esetben a nyírást tisztán szinuszosnak választjuk:

$$
\gamma(t)=\gamma_{0} \cdot \sin (\omega \cdot t)
$$

ahol $\gamma_{0}$ a nyírás amplitúdója, $\omega$ pedig a nyírás körfrekvenciája. A nyírási sebesség könnyen adódik, hiszen az nem más, mint a nyírás idő szerinti deriváltja:

$$
\dot{\gamma}(t)=\dot{\gamma}_{0} \cdot \cos (\omega \cdot t)
$$

ahol $\dot{\gamma}_{0}=\gamma_{0} \cdot \omega$, a nyírási sebesség amplitúdója.

Lineáris viszkoelasztikus folyadék esetén, ha a nyírás tisztán szinuszos, akkor a nyírófeszültség is tisztán szinuszos függvény lesz, csak az amplitúdó és a fázis változhat. Nemlineáris folyadék esetén akkor hasonló a helyzet, ha a gerjesztést megfelelően kicsire választjuk, azaz a lineáris tartományon belül maradunk - ezért is kapta a SAOS nevet. A nyírófeszültség jel ekkor a következő alakban írható:

$$
\sigma(t)=\sigma_{0} \cdot \sin (\omega \cdot t+\delta)
$$

itt $\sigma_{0}$ a nyírási amplitúdó, $\delta$ a fáziskülönbség. Trigonometrikus átalakításokkal kapjuk, hogy:

$$
\sigma(t)=\sigma_{0} \cdot \sin (\omega \cdot t) \cdot \cos (\delta)+\sigma_{0} \cdot \cos (\omega \cdot t) \cdot \sin (\delta)
$$


Viszkoelasztikus minták jellemzésére használatos reológiai függvények, az úgynevezett tárolási $\left(G^{\prime}(\omega)\right)$ illetve veszteségi $\left(G^{\prime \prime}(\omega)\right)$ modulusok, amelyeket a következőképpen definiálunk [14]:

$$
\frac{\sigma(t)}{\gamma_{0}}=G^{\prime} \cdot \sin (\omega \cdot t)+G^{\prime \prime} \cdot \sin (\omega \cdot t)
$$

Összevetve a 2.10 és a 2.11. egyenleteket kapjuk, hogy:

$$
\begin{aligned}
& G^{\prime}(\omega)=\frac{\sigma_{0}}{\gamma_{0}} \cdot \cos (\delta) \\
& G^{\prime \prime}(\omega)=\frac{\sigma_{0}}{\gamma_{0}} \cdot \sin (\delta)
\end{aligned}
$$

SAOS mérések esetén a dinamikai viszkozitással analóg mennyiség az ún. komplex viszkozitás:

$$
\eta^{*}=\frac{\sigma_{0}}{\gamma_{0}} \cdot i e^{i \delta}
$$

Ennek abszolút értéke a tárolási és veszteségi modulusokból az alábbi formulával számolható [14]:

$$
\left|\eta^{*}(\omega)\right|=\sqrt{\left(\frac{G^{\prime}(\omega)}{\omega}\right)^{2}+\left(\frac{G^{\prime \prime}(\omega)}{\omega}\right)^{2}}
$$

Tisztán viszkózus esetben (newtoni folyadék) a 2.4 konstitutív egyenlet alapján adódik, hogy $G^{\prime}=0$, valamint $G^{\prime \prime}=\eta \cdot \omega$, tehát azt mondhatjuk, hogy a veszteségi modulusz ad számot a vizsgált anyag viszkózusságáról.

Tökéletesen rugalmas esetben (Hooke-test) a 2.5 konstitutív egyenlet felhasználásával adódik, hogy $G^{\prime}=k$, valamint $G^{\prime \prime}=0$, tehát azt mondhatjuk, hogy a tárolási modulusz ad számot a vizsgált anyag rugalmasságáról.

Nézzük meg mit kapunk egy $n$ elemü Maxwell-modell esetén! A konstitutív egyenletekbe (2.6 alakú egyenlet minden Maxwell-elemre külön paraméterekkel) tisztán szinuszos nyírási sebességet írunk be és megkeressük a nyírófeszültség megoldásait, amelyek szintén tisztán szinuszos függvények lesznek. Newton negyedik törvénye szerint az erők vektorként összegezhetők, így az egyes elemekre jutó mechanikai nyírófeszültségek összeadhatók, azaz az $n$ elemü összeg egyetlen szinuszos taggá 
alakítható. A definíciók felhasználásával (2.12 és 2.13 egyenletek) a tárolási modulusz és a veszteségi modulusz értékei az alábbi alakot öltik [15]:

$$
\begin{aligned}
& G^{\prime}(\omega)=\sum_{i=1}^{n} \frac{\eta_{i} \lambda_{i} \omega^{2}}{1+\lambda_{i}^{2} \omega^{2}} \\
& G^{\prime \prime}(\omega)=\sum_{i=1}^{n} \frac{\eta_{i} \omega}{1+\lambda_{i}^{2} \omega^{2}},
\end{aligned}
$$

ahol $\lambda_{i}=\frac{\eta_{i}}{k_{i}}$, a relaxációs idő. A relaxációs időnek szemléletes jelentése van: a feszültség relaxációs mérés estén az anyag válaszának relaxációs idejét jelenti.

\subsubsection{Cox-Merz szabály}

A most megismert Maxwell-modell egy jól bevált eszköz az anyagok lineáris viszkoelasztikus tulajdonságainak leírására. Mindazonáltal sok jelenség leírása túlmutat a modell képességein, így például a viszkoelasztikus folyadékokra igen gyakran érvényes Cox-Merz szabályt sem teljesíti.

A Cox-Merz szabály egy empirikus összefüggés, amely szerint az anyag dinamikai viszkozitás - nyírási sebesség görbéje ugyanolyan lefutású és számértékileg is megegyező a komplex viszkozitás abszolút érték - körfrekvencia görbével. Azzal a feltétellel, hogy a nyírási sebesség (1/s-ban mérve) számértékileg megegyezik a körfrekvenciával (rad/s-ban mérve) [16].

$$
\left|\eta^{*}(\omega)\right|=\left.\eta(\dot{\gamma})\right|_{\omega=\dot{\gamma}}
$$

Ez az empirikus összefüggés igen sok polimer rendszerre igaz a kis és közepes körfrekvenciák tartományában. Ez a módszer lehetőséget nyújt a nehezen hozzáférhető nemlineáris dinamikai viszkozitás meghatározására SAOS mérések segítségével.

\subsubsection{Nemlineáris viszkoelasztikus folyadékok}

Az utóbbi évtizedekben a nemlineáris viszkoelasztikus folyadékok reológiai vizsgálata intenzív kutatási területté vált. Ugyanis a viszkoelasztikus folyadékok döntő többsége ebbe a csoportba tartozik, úgy mint a polimer-olvadékok, az élő szervezetekben 
előforduló folyadékok jelentős része, az élelmiszeripari alapanyagok, stb. Elmondható, hogy ezen anyagok viselkedésének pontos leírása igen fontos mind az orvosi, biológiai, kémiai és mérnöki tudományok területén. Az ilyen anyagok lineáris viszkoelasztikus viselkedése a korábbiakban bemutatott SAOS tesztekkel lehetséges. A nemlineáris viszkoelasztikus viselkedés kísérleti leírására a legelterjedtebb módszer az úgynevezett LAOS (Large Amplitude Oscillatory Shear) tesztek alkalmazása, a következö témakörben bővebben is foglalkozom ezzel a módszerrel.

A nemlineáris viszkoelasztikus viselkedés leírására szolgáló konstitutív egyenletek már koncentrált paraméterü modellként is igen bonyolultak lehetnek [17]. Az alábbiakban az általunk használt koncentrált paraméterü White-Metzner-modellt mutatom be részletesebben, ami a Maxwell-modell egy szemléletes nemlineáris általánosítása.

\subsubsection{White-Metzner-modell}

Egy egyszerü és kézenfekvő módszer a nemlineáris viszkoelasztikus folyadékok leírására az úgynevezett White-Metzner-modell [18], amely a Maxwell-modell egy lehetséges nemlineáris változata. A Maxwell-modellben a lineáris viszkózus tagot egy nemlineáris $\eta(\dot{\gamma})$ viszkózus taggal helyettesítjük, így a következő konstitutív egyenletet kapjuk (White-Metzner-modell):

$$
\dot{\gamma}(t)=-\frac{1}{\eta(\dot{\gamma}(t))} \cdot \sigma(t)-\frac{1}{k} \dot{\sigma}(t)
$$

A nemlineáris viszkózus tag meghatározása az anyagon végzett mérések alapján a modellalkotás fontos lépése. 


\subsection{Nagyfrekvenciás reometriai mérések}

Az anyagok nagyfrekvenciás reológiai leírása az utóbbi idők egyik széles körben vizsgált területté nőtte ki magát. Ennek két fő oka van. Egyrészt számos anyagot olyan nagyfrekvenciájú oszcilláló rendszerekben használnak, ahol pontos reológiai leírásuk elengedhetetlen a tervezéshez (pl. motorok lengéscsillapítójában alkalmazott folyadékok), másrészt az anyag pillanatnyi, hirtelen viselkedésére tudunk következtetni a nagyfrekvenciás viselkedésből.

A probléma a nagyfrekvenciás leírással az, hogy a konvencionális reométerek maximum $100 \mathrm{~Hz}$ frekvencia értékig képesek az anyagok lineáris viszkoelasztikus tulajdonságait megmérni. Ha a vizsgált anyag termoreológiailag egyszerü, azaz teljesíti a TTS (Time Temperature Superposition) szabályt [14, 15], akkor a különböző hőmérsékleten a körfrekvencia függvényében mért tárolási és veszteségi modulusz görbék kétszer logaritmikus skálán ábrázolva horizontális (horizontális eltolási faktor) és vertikális (vertikális eltolási faktor) eltolásokkal egymásba tolhatóak. Az összetolásokkal a frekvencia tartomány kiterjeszthető, mértéke a vizsgált anyagtól függ. Ha ez a kiterjesztés nem elegendő, vagy maga az anyag nem is teljesíti a TTS szabályt, úgy más módszereket kell keresni a nagyfrekvenciás reológiai tulajdonságok mérésére.

Kevés módszer létezik az anyagok nagyfrekvenciás reológiai tulajdonságainak mérésére. Két csoportra szokták osztani a meglévő technikákat: mechanikai és optikai reológiai módszerek. A továbbiakban röviden bemutatok néhány ilyen módszert, majd az általunk alkalmazott DWS módszerrel külön is foglalkozom.

\subsubsection{Mechanikai módszerek}

Piezo-elektromos módszer (Piezo-driven shear and squeeze flow rheometer): mind az áramláskialakításokat, mind a minta válaszának mérését piezoelektromos átalakítók végzik. Tipikusan a 0,1 és $10 \mathrm{kHz}$ frekvencia tartományban alkalmazható módszer [19, 20].

Ultrahang módszer (Ultrasonic shear rheometers): egy piezoelektromos kristályrezonátor hozza oszcillációba a komplex folyadékot. Vizsgálva a hullám behatolási mélységét, az anyag tárolási és veszteségi modulusai egészen a $\mathrm{MHz}$ frekvencia értékig kiszámolhatók [19, 21]. 


\subsubsection{Optikai módszerek}

Lehetőségünk van mikroreológiai módszerekkel is vizsgálni az anyagok viszkoelasztikus tulajdonságát. Ilyenkor olyan „nyomjelző” részecskékre van szükség, amelyek a beérkező fénnyel valamilyen kölcsönhatásba tudnak lépni. Ilyen részecskéket vagy tartalmaz maga a megvilágított molekula, vagy nekünk kell a mintában eloszlatni. A részecskék mozgását optikai módszerekkel vizsgáljuk, amelyböl kiszámíthatók a folyadék reológiai tulajdonságai. Aktív mikroreológiáról akkor beszélünk, ha a részecskék mozgását mi idézzük elő (valamilyen erőt gyakorlunk rájuk). A passzív mikroreológiás eljárásoknál a részecskék véletlenszerü hőmozgását (Brown-mozgás) vizsgáljuk, ennek segítségével anélkül határozhatjuk meg a folyadék viszkoelasztikus tulajdonságait, hogy áramlásba hoznánk a mintát. Természetesen, ilyenkor a lineáris viszkoelasztikus tartományban vagyunk, hiszen a minta nyugalomban van [22].

\subsubsection{DWS-módszer}

Ahhoz, hogy magasabb frekvencia tartományokban is képesek legyünk a szilikonolaj reológiai jellemzésére, a DWS (Diffusing Wave Spectroscopy) eljárást alkalmaztuk [23, 24]. Ez a módszer a passzív mikroreológiai eljárások körébe tartozik. Ez egy olyan optikai technika, amely a fény mintán való szóródását vizsgálja. Sematikus vázlatát a 8 . ábra mutatja be.

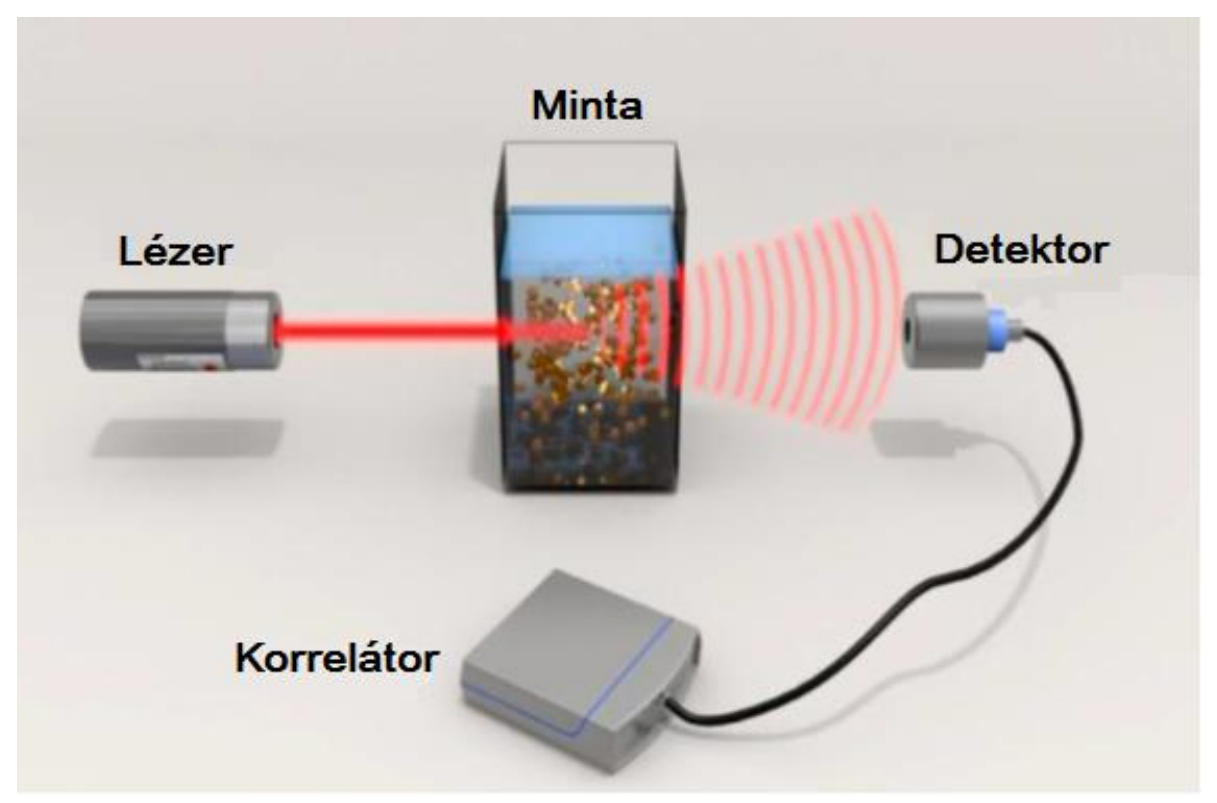

8. ábra: A mikroreológiai DWS-módszer működési elvének szemléltetése 
A lényege az, hogy egy lézernyalábbal világítjuk meg a folyadékmintánkat. A beérkező fény többször szóródik a minta részecskéin. Egy detektorral megmérjük a szórt fény intenzitását az idő függvényében. Ennek a korrelációs tulajdonságaiból kiszámítható a fényt szóró részecskék véletlen hőmozgásának átlagos négyzetes elmozdulása, amelyet a korrelátor végez. Az elmozdulásból mikroreológiai számításokkal megkaphatjuk az anyagra jellemző elasztikus és viszkózus tulajdonságokat, azaz a tárolási (G') és veszteségi $(G ”)$ moduluszt $[25,26]$. A DWS-módszerrel tipikusan a $10^{-1}-10^{7} \mathrm{~Hz}$ frekvencia tartományban lehet a G', G” értékeket megkapni. 


\subsection{Nagy amplitúdojjú oszcillációs nyírás (LAOS)}

Igen sok felhasználási területen a folyadékra ható deformáció mértéke már nem tekinthető kicsinek. Ezekben az esetekben már a nemlineáris viszkoelasztikus tulajdonságok befolyásolják az anyagi viselkedést. A nagy amplitúdójú oszcillációs nyírási tesztek (LAOS, Large Amplitude Oscillatory Shear) módszere egy széles körben alkalmazott és jól definiált eljárás [27] az anyagok nemlineáris viszkoelasztikus tulajdonságainak feltérképezésére. A módszer lényege az, hogy egy tisztán szinuszos nyírást (2.7 egyenlet) adunk a vizsgálandó anyagra, és elemezzük a mért időfüggő nyírófeszültségi jelet. A nyírás körfrekvenciájának és amplitúdójának változtatásával megadhatók az anyag részletes nemlineáris viszkoelasztikus tulajdonságai.

A LAOS vizsgálatokat két bemeneti paraméter határozza meg: az alkalmazott nyírási amplitúdó és körfrekvencia $\left\{\gamma_{0}, \omega\right\}$. A két bemeneti paraméter egy kétdimenziós vizsgálati teret definiál, amelyben az összes eredmény ábrázolható. Az ilyen típusú ábrázolást nevezik Pipkin-diagramnak [28].

A LAOS mérések eredményeinek elemzésére többfajta eljárás is ismert. A legegyszerübb, ha a mért $\sigma(t)$ nyírófeszültséget a bemenő $\gamma(t)$ nyírás illetve $\dot{\gamma}(t)$ nyírási sebesség függvényében ábrázoljuk. Az így kapott görbék az elasztikus, illetve viszkózus Lissajous-Bowditch görbék [29-33]. Az ellipszistől eltérő alakú zárt görbék a nemlineáris tartományt jelölik, így a görbék alakjából rögtön elkülöníthető a vizsgált anyagra jellemző lineáris és nemlineáris tartomány [34]. A 9. ábrán fekete vonallal ábrázoltam az elasztikus és viszkózus Lissajous-Bowditch görbéket egy nemlineáris esetben.

Jelen dolgozatban két mára már alapvetőnek számító LAOS elemzésre alkalmas módszert használtam: a Fourier transzformációs reológiai [35] és az Ewoldt által publikált eljárásokat [48].

\subsubsection{Fourier transzformációs reológia (FTR)}

A Fourier transzformációs reológiai (FTR, Fourier Transform Rheology) módszer lényege [35], összhangban más Fourier transzformációs módszerrel az, hogy vesszük a mért nyers periodikus nyírófeszültségi jel Fourier felbontását, amely a következő alakú lesz [36]: 


$$
\sigma\left(t ; \omega, \gamma_{0}\right)=\gamma_{0} \cdot \sum_{n: \text { páratlan }}\left(G_{n}^{\prime}\left(\omega, \gamma_{0}\right) \cdot \sin (n \cdot \omega \cdot t)+G_{n}^{\prime \prime}\left(\omega, \gamma_{0}\right) \cdot \cos (n \cdot \omega \cdot t)\right)
$$

A Fourier felbontás csak a páratlan harmonikusakat tartalmazza, mivel a nyírófeszültség jelnek páratlan függvénynek kell lennie a nyírás vagy nyírási sebesség függvényre nézve $\sigma(-\gamma(t))=-\sigma(\gamma(t))$. Ez azért szükséges, mert elvárjuk, hogy az anyag által adott válasz (nyírófeszültség) változatlan maradjon, ha a koordinátarendszert megfordítjuk [37]. Páros felharmonikus tagok megjelenését a falon való megcsúszás (wall slip), másodlagos áramlások (secondary flows), illetve az aszimmetrikus mérőgeometriák okozhatnak [38]. Ezekkel a jelenségekkel a továbbiakban külön nem foglalkozom, mivel a méréseink során páros felharmonikus tagok nem, illetve csak elhanyagolható mértékben jelentek meg. A 2.18-as egyenletböl az is látható, hogy a nyírófeszültség Fourier felbontás során kapott együtthatói a származtatott tárolási és veszteségi modulusoknak felelnek meg. Amennyiben a nyírás amplitúdója még kellően alacsony, és így a mért nyírófeszültség jel is még tisztán szinuszos, a fenti egyenlet a lineáris viszkoelasztikus rendszerek bemutatásánál ismertetett 2.11-es képletbe megy át. Az anyag nemlineáris viselkedését a felharmonikus tagok megjelenése mutatja (ekkor már a mért nyírófeszültség jel nem tisztán szinuszos). A Fourier transzformációs reológiában a nemlinearitás mértékét a harmadik felharmonikus és alapharmonikus együtthatók hányadosával $\frac{\mathrm{G}_{3}^{\prime}}{\mathrm{G}^{\prime}{ }_{1}}$, illetve $\frac{\mathrm{G}^{\prime \prime}{ }_{3}}{\mathrm{G}^{\prime \prime}{ }_{1}}$ adjuk meg. A legtöbb esetben a magasabb felharmonikusok elhanyagolhatóak, így azok alapharmonikushoz viszonyított arányát nem szokás megadni.

A Fourier transzformációs módszer számos különböző típusú komplex folyadékra alkalmazható, többek között emulziókra [39], szuszpenziókra [40], híg és koncentrált polimer oldatokra, valamint polimer olvadékokra [41-46].

Az FTR elemzés legnagyobb hiányossága, hogy a kapott $\mathrm{G}_{\mathrm{n}}^{\prime}, \mathrm{G}^{\prime \prime}{ }_{\mathrm{n}}$ Fourier együtthatóknak a $G^{\prime}{ }_{1}, G^{\prime \prime}{ }_{1}$ alapharmonikus együtthatókon kívül nincs valódi fizikai jelentésük. Nem tudunk rögtön következtetni az anyag belső nemlineáris tulajdonságaira egy megadott $\omega$ és $\gamma_{0}$ értéknél. Az egyik lehetőség a probléma megoldására a Cho-féle nyírófeszültség-felbontásból (stress decomposition) indul ki [47]. A cikk szerint a nyírófeszültség két részre bontható, egy elasztikus, és egy viszkózus nyírófeszültségre $\sigma(\mathrm{t})=\sigma^{\prime}(\mathrm{t})+\sigma^{\prime \prime}(\mathrm{t})$, ahol az elasztikus feszültség páros függvény a nyírásra és páratlan függvény a nyírási sebességre nézve; a viszkózus feszültség pedig páratlan függvény a 
nyírásra és páros függvény a nyírási sebességre nézve. Az alábbi egyenletek mutatják a Cho-féle feszültségfelosztást, valamint kapcsolatukat a Fourier felbontással [47].

$$
\begin{aligned}
& \sigma^{\prime}(t) \equiv \frac{\sigma(\gamma, \dot{\gamma})-\sigma(-\gamma, \dot{\gamma})}{2}=\sum_{n: \text { áratlan }} G_{n}^{\prime}\left(\omega, \gamma_{0}\right) \cdot \sin (n \cdot \omega \cdot t) \\
& \sigma^{\prime \prime}(t) \equiv \frac{\sigma(\gamma, \dot{\gamma})-\sigma(\gamma,-\dot{\gamma})}{2}=\sum_{n: \text { áratlan }} G_{n}^{\prime \prime}\left(\omega, \gamma_{0}\right) \cdot \cos (n \cdot \omega \cdot t)
\end{aligned}
$$

Így ábrázolva (9. ábra) az elasztikus nyírófeszültséget a nyírás függvényében (pontozott kék vonal), illetve a viszkózus nyírófeszültséget a nyírási sebesség függvényében (szaggatott piros vonal) megilleszthető egyértékü függvényeket kapunk, ellentétben a nyírófeszültségnek a nyírás illetve nyírási sebesség függvényében adódó zárt hurkaival.
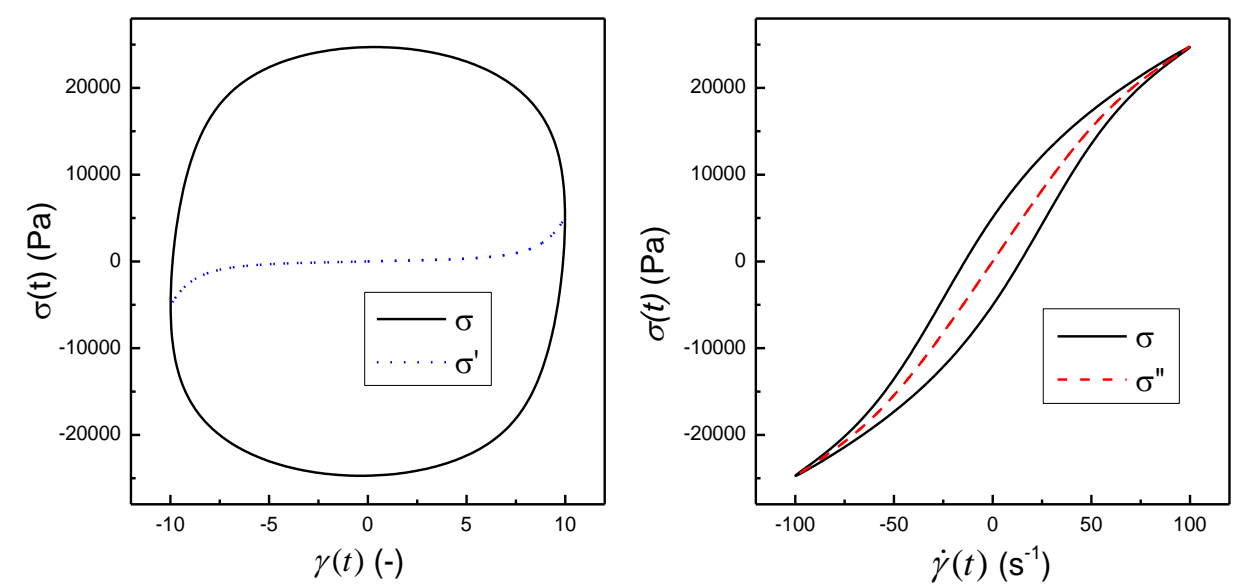

9. ábra: Elasztikus és viszkózus Lissajous-Bowditch görbék egy nemlineáris esetben (fekete vonalak), valamint a hozzájuk tartozó elasztikus (pontozott kék vonal) és viszkózus nyírófeszültség (szaggatott piros vonal) görbék

A legkézenfekvőbb illesztés a polinomiális függvénnyel való közelítés, azonban ennek nagy hiányossága az, hogy a polinomiális együtthatók nem egyértelműek, abban az értelemben, hogy azok a felhasználó által kiválasztott polinom fokszámától függenek. Tegyük fel, hogy van egy ismeretlen sima $\mathrm{F}(\mathrm{x})$ függvényünk. Ha egy elsőrendü polinomot illesztünk a függvényre $F(\mathrm{x})=a_{0}+a_{1} \cdot x$, akkor a kapott $a_{0}, a_{1}$ együtthatók értékei jelentősen különbözni fognak egy magasabb rendü polinomiális illesztés $F(\mathrm{x})=b_{0}+b_{1}$. $x+b_{2} \cdot x^{2}+\cdots$ együtthatóitól. Így ezek az együtthatók nem számszerüsítik egyértelmüen az anyagra vonatkozó belső nemlinearitást. Olyan $F(\mathrm{x})=a_{0} \cdot f_{0}(x)+a_{1} \cdot f_{1}(x)+a_{2}$. $f_{2}(x)+\cdots f_{n}(x)$ függvényeket keresünk, amelyek teljesítik az alábbi három kritériumot: 
- véges tartományban ortogonálisak,

- $\quad \mathrm{x}=0$ körül páratlan függvényként viselkednek, és

- magasabb rendủ a tagok korlátossága.

A Csebisev-féle polinomok mindhárom feltételnek megfelelnek, így ez egy megfelelő választás. Az elasztikus és viszkózus nyírófeszültség így a következő alakban írható:

$$
\begin{aligned}
& \sigma^{\prime}(x)=\gamma_{0} \cdot \sum_{n: \text { páratlan }} e_{n}\left(\omega, \gamma_{0}\right) \cdot T_{n}(x) \\
& \sigma^{\prime \prime}(x)=\gamma_{0} \cdot \omega \sum_{n: \text { áratlan }} v_{n}\left(\omega, \gamma_{0}\right) \cdot S_{n}(x)
\end{aligned}
$$

ahol $T_{n}(x)$ az $n$-ed fokú Csebisev-polinom, $x$ a normált nyírás $x=\frac{\gamma(t)}{\gamma_{0}}=\sin (\omega \cdot t), \mathrm{y}$ pedig a normált nyírási sebesség $y=\frac{\dot{\gamma}(t)}{\gamma_{0} \cdot \omega}=\sin (\omega \cdot t)$. Az $e_{n}\left(\omega, \gamma_{0}\right)$ paramétert elasztikus Csebisev együtthatónak, míg a $v_{n}\left(\omega, \gamma_{0}\right)$ paramétert viszkózus Csebisev együtthatónak nevezzük. A lineáris tartományban $e_{3} / e_{1} \ll 1$ és $v_{3} / v_{1} \ll 1$ ilyenkor a fenti egyenletek (2.19-2.22) alapján $e_{1} \rightarrow G^{\prime}$ és $v_{1} \rightarrow \eta^{\prime}=G^{\prime \prime} / \omega$. Ha megjelenik a nemlináris jelleg, például az $n=3$ harmonikus pozitív előjellel, akkor a harmadrendủ polinomból azonnal látható, hogy az elasztikus nyírófeszültség értéke nagyobb lesz, mint amennyit csak az elsőrendű polinomból kapnánk. Ezért, ha $e_{3}>0$, akkor ciklikusan nyírásra keményedő (intracycle strain stiffening), míg ha $e_{3}<0$, akkor ciklikusan nyírásra lágyuló (intracycle strain softening) folyadékról beszélhetünk. Hasonlóképpen, ha $v_{3}>0$, akkor ciklikusan dilatáló (intracycle shear thickening), míg ha $v_{3}<0$, akkor ciklikusan pszeudoplasztikus (intracycle shear thinning) folyadékról beszélhetünk [48]. A Csebisev-polinomok használatának egy további előnye, hogy a Csebisev együtthatók könnyen kifejezhetők a Fourier együtthatók segítségével:

$$
\begin{aligned}
& e_{n}=G_{n}^{\prime} \cdot(-1)^{\frac{n-1}{2}} n: \text { páratlan } \\
& v_{n}=\frac{G_{n}^{\prime \prime}}{\omega}=\eta_{n}^{\prime} \quad n: \text { páratlan }
\end{aligned}
$$

Ha a harmadrendü Csebisev együtthatókról beláttuk, hogy alkalmasak a lineáris viszkoelasztikus viselkedéstől való eltérés fizikai értelmezésére, úgy a fenti képlet alapján 
a Fourier együtthatók is. Természetesen figyelni kell, hogy az előjeleket megfelelően kezeljük.

Ezek alapján könnyen belátható, hogy a nemlinearitás nagyságának vizsgálatára

inkább használatos $\frac{e_{3}}{e_{1}}$ és $\frac{\mathrm{v}_{3}}{\mathrm{v}_{1}}$ mennyiségek megegyeznek a FTR módszerrel kapott $-\frac{\mathrm{G}^{\prime}{ }_{3}}{\mathrm{G}^{\prime}{ }_{1}}$, illetve $\frac{\mathrm{G}^{\prime \prime}{ }_{3}}{\mathrm{G}_{1}{ }_{1}}$ mennyiségekkel.

\subsubsection{Ewoldt-módszer}

Ewoldt és munkatársai egy egészen más módszert alkalmaztak az anyagok nemlineáris viszkózus és elasztikus tulajdonságainak vizsgálatára. Az elasztikusság szemléltetésére két tárolás modulusz paramétert, míg a viszkozitás jellemzésére két dinamikai viszkozitás paramétert definiált [48]:

$$
\begin{array}{ll}
\left.\left.G_{M}^{\prime} \equiv \frac{d \sigma}{d \gamma}\right|_{\gamma=0} \quad G_{L}^{\prime} \equiv \frac{\sigma}{\gamma}\right|_{\gamma= \pm \gamma_{0}} \\
\left.\left.\eta_{M}^{\prime} \equiv \frac{d \sigma}{d \dot{\gamma}}\right|_{\dot{\gamma}=0} \quad \eta_{L}^{\prime} \equiv \frac{\sigma}{\dot{\gamma}}\right|_{\dot{\gamma}= \pm \dot{\gamma}_{0}},
\end{array}
$$

ahol $G_{M}^{\prime}$ (minimum-strain elastic moduli) a tárolási modulusz a minimális nyírási értéknél, azaz $\gamma=0$-nál, illetve $G_{L}^{\prime}$ (large-strain elastic moduli) a tárolási modulusz az alkalmazott maximális nyírásnál. Hasonlóképpen, $\eta_{M}^{\prime}$ (minimum-rate dynamic viscosity) a dinamikai viszkozitás a minimális nyírási sebesség értéknél, azaz $\dot{\gamma}=0$-nál, illetve $\eta_{L}^{\prime}$ (large-rate dynamic viscosity) a dinamikai viszkozitás az alkalmazott maximális nyírási sebességnél. 

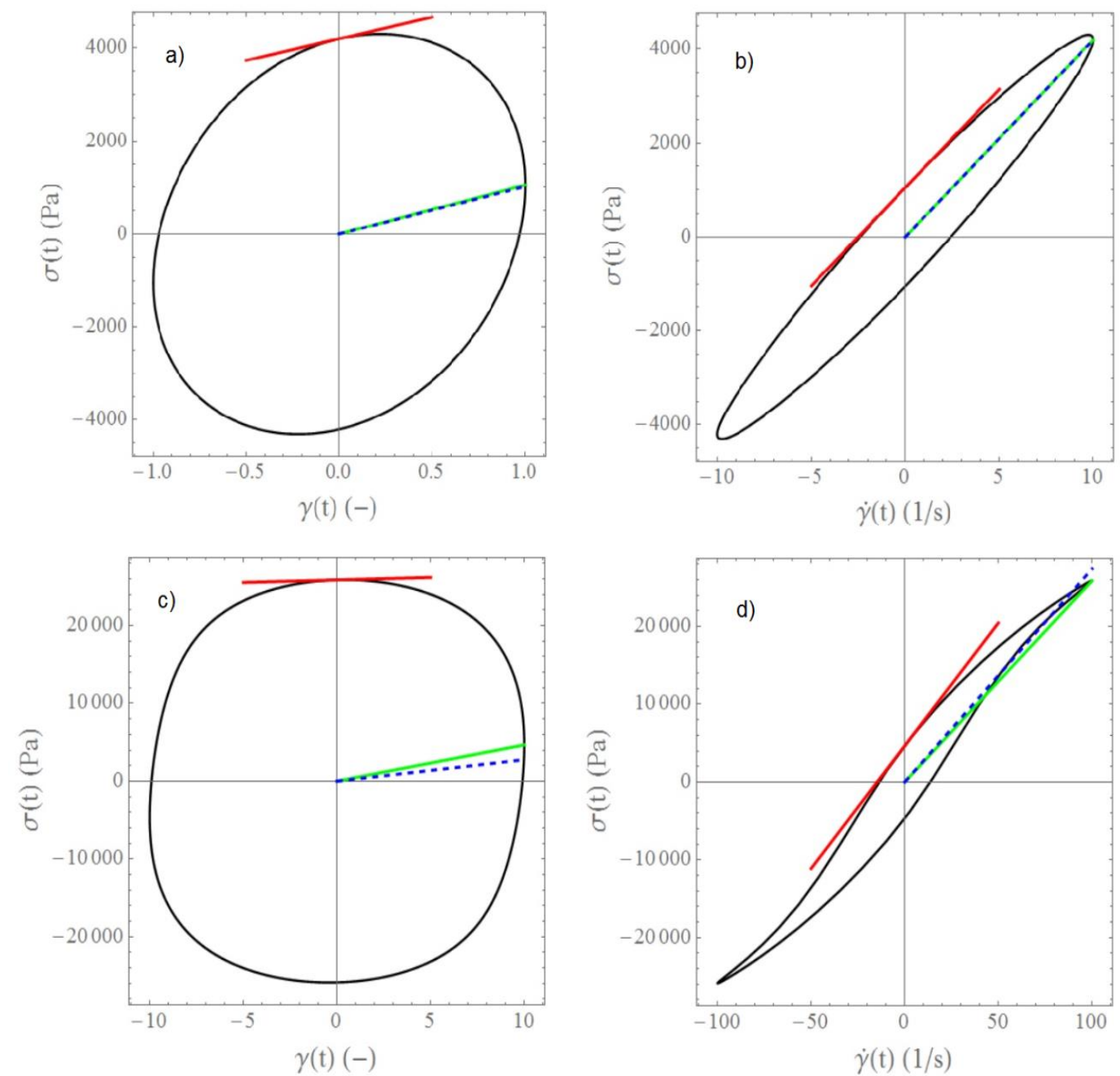

10. ábra: Ewoldt által definiált elasztikus (a és c grafikon) és viszkózus (c és d grafikon) paraméterek ábrázolása a lineáris (a és b grafikon) és nemlineáris (c és d grafikon) esetben. A maximumhoz tartozó mennyiségeket zöld, míg a minimumhoz tartozó mennyiségeket piros vonallal ábrázoltuk. A kék szaggatott vonalak pedig az alap harmonikushoz tartozó reológiai mennyiségeket ábrázolják.

A fent definiált négy mennyiséget legegyszerübben grafikus módon lehet szemléltetni (10. ábra). A PDMS mintán mért LAOS tesztekből szerkesztett elasztikus és viszkózus Lissajous-Bodwitch görbéken közvetlenül láthatóak az Ewoldt által definiált mennyiségek. A fekete görbék a mért nyírófeszültség értékeket jelzik a nyírás (a és c ábrarész), illetve a nyírási sebesség (b és d ábrarész) függvényében. A piros érintő egyenesek meredeksége a minimum $G_{M}^{\prime}$ és $\eta_{M}^{\prime}$, a zöld vonalak meredeksége a nagy $G_{L}^{\prime}$ és $\eta_{L}^{\prime}$, míg a szaggatott kék vonalak meredeksége pedig az alap harmonikushoz tartozó (átlagos) $\mathrm{G}_{1}^{\prime}$ és $\eta_{1}^{\prime}=\mathrm{G}^{\prime \prime}{ }_{1} / \omega$ reológiai mennyiségeket mutatják. A lineáris tartományban, vagyis ahol a mért nyírófeszültség még tisztán szinuszos, a megfelelő reológiai mennyiségek megegyeznek: $G_{M}^{\prime}=G_{L}^{\prime}=G_{1}^{\prime}=e_{1}$ és $\eta_{M}^{\prime}=\eta_{L}^{\prime}=\eta_{1}^{\prime}=v_{1}$, ez látható a 
10. ábra (a) és (b) részén. A nemlineáris estben ezek a mennyiségek különböznek egymástól, ahogyan ez a 10. ábra (c) és (d) részén látható.

Ewoldt és munkatársai két, az imént definiált mennyiségekből származtatott paraméterrel jellemezték az anyag ciklikus nemlinearitását (intracycle nonlinearities). Az elasztikus tulajdonságot mutató $S$ arány (strain stiffening ratio) a következőképpen számolható [48]:

$$
S \equiv \frac{G_{L}^{\prime}-G_{M}^{\prime}}{G_{L}^{\prime}}=\frac{4 \cdot e_{3}+\ldots}{e_{1}+e_{3}+\ldots}
$$

Ha az $S=0$, akkor a lineáris elasztikus tartományban vagyunk, amennyiben $S>0$, akkor ciklikusan nyírásra keményedő, míg ha $S<0$, akkor ciklikusan nyírásra lágyuló viselkedést mutat a vizsgált folyadék.

Hasonlóképpen a viszkózus tulajdonságot mutató $T$ arány (shear thickening ratio) a következőképp számolható [48]:

$$
T \equiv \frac{\eta_{L}^{\prime}-\eta_{M}^{\prime}}{\eta_{L}^{\prime}}=\frac{4 \cdot v_{3}+\ldots}{v_{1}+v_{3}+\ldots}
$$

Ha a $T=0$, akkor a lineáris viszkózus tartományban vagyunk, amennyiben $T>0$, akkor ciklikusan dilatáló, míg ha $T<0$, akkor ciklikusan pszeudoplasztikus viselkedést mutat a vizsgált folyadék. 


\subsection{Térfüggö reológiai modellek}

A 2.1 -es fejezetben említettem, hogy a reológiában az a cél, hogy a bonyolult kapcsolt vektor és tenzoregyenletek helyett egyszerübb koncentrált paraméterü egyenleteket alkalmazhassunk. A valóságban azonban a legtöbbször figyelembe kell venni a konstitúciós egyenletben szereplő nyírófeszültség és nyírási sebesség helytől való függését is. A helyfüggő konstitúciós egyenleteket legkönnyebben a koncentrált modellek általánosításával kapjuk. Ilyenkor természetesen a nyírófeszültséget és a nyírási sebességet is tenzorként kell kezelni. Descartes koordinátarendszerben a nyírási sebesség tenzor a következő szimmetrikus alakot ölti $[15,17]$ :

$$
\underline{\underline{\sigma}}=\left(\begin{array}{ccc}
\sigma_{x x} & \sigma_{x y} & \sigma_{x z} \\
\sigma_{x y} & \sigma_{y y} & \sigma_{y z} \\
\sigma_{x z} & \sigma_{y z} & \sigma_{z z}
\end{array}\right)
$$

A nyírási sebesség tenzort pedig a következőképp definiáljuk [15]:

$$
\underline{\dot{\gamma}}=\nabla \cdot \underline{\mathrm{v}}+(\nabla \cdot \underline{\mathrm{v}})^{T}
$$

ahol $\underline{\mathrm{v}}(x, y, z, t)$ a kialakult sebességmező. A definíció alapján könnyen látható, hogy a nyírási sebesség tenzor is szimmetrikus. Jól látszik, hogy a 2. ábrán látható esetben, ahol a kialakult sebességmezőnek csak $x$ irányú komponense van, a nyírási sebesség tenzor a következő egyszerü alakot ölti:

$$
\dot{\gamma}=\left(\begin{array}{ccc}
0 & \frac{\partial \mathrm{v}_{x}}{\partial y} & 0 \\
\frac{\partial \mathrm{v}_{x}}{\partial y} & 0 & 0 \\
0 & 0 & 0
\end{array}\right)=\left(\begin{array}{ccc}
0 & \dot{\gamma}_{x y} & 0 \\
\dot{\gamma}_{x y} & 0 & 0 \\
0 & 0 & 0
\end{array}\right),
$$

vagyis newtoni folyadékok estében $\underline{\underline{\sigma}}=-\eta \cdot \underline{\underline{\gamma}}$ visszakapjuk a 2.4 es egyenletet.

A nagy deformációk elmélete alapján a konstitúciós egyenletekben szereplő idő szerinti deriváltat nem elegendő a hidrodinamikai deriválttal helyettesíteni, hanem további korrekciós tagokra is szükség van [15]. Többfajta, különböző korrekciós tagokat tartalmazó derivált található erre a célra a szakirodalomban (pl.: upper(lower)-convected derivált, Gordon-Schowalter, stb.). Mindegyik derivált más és más tulajdonságok leírására alkalmas. Mi a dolgozatban a legegyszerúbb, ún. upper-convected deriválttal dolgozunk, 
így ezt mutatjuk be részletesen. Bármely koncentrált paraméterü modellt könnyen térfüggővé alakíthatunk, ha az konstitutív egyenletben szereplő nyírófeszültség és nyírási sebességet tenzor alakban szerepeltetjük, valamint, hogy az idő szerint derivált bonyolultabb, valamely korrekciós tagokkal definiált alakját használjuk. Azonban nem triviális az, hogy a sok koncentrált paraméterü modell közül melyiket és milyen módon alakítsuk át, ez függ a vizsgált anyag komplexitásától, és a leírni kívánt fizikai viselkedéstől is. Léteznek viszonylag egyszerü és igen bonyolult térfüggő modellek is [13]. Mi a legegyszerübb többelemű Maxwell-modell, illetve a White-Metzner-modell térfüggő változatait használtuk, az alábbiakban ezeket ismertetem részletesebben.

\subsubsection{Upper-convected derivált}

Az upper convected deriváltat a következőképp definiáljuk [15]:

$$
\stackrel{\nabla}{\underline{\underline{A}}} \equiv \frac{D \underline{\underline{A}}}{D t}-(\nabla \cdot \underline{\mathrm{v}})^{T} \cdot \underline{\underline{A}}-\underline{\underline{A}} \cdot(\nabla \cdot \underline{\mathrm{v}})
$$

ahol $\underline{\underline{A}}$ a deriválandó tenzor, $\nabla$ a nabla operátor, valamint a $\frac{\mathrm{D}}{\mathrm{Dt}}$ operátor a hidrodinamikai derivált:

$$
\frac{D \underline{\underline{A}}}{D t}=\frac{\partial \underline{\underline{A}}}{\partial t}+\underline{v} \cdot(\nabla \cdot \underline{\underline{A}})
$$

\subsubsection{Upper-convected Mawell-modell (UCM-modell)}

Bármely anyag lineáris viszkoelasztikus viselkedése leírható egy $n$ elemű Maxwellmodellel, amely egy egyszerü koncentrált paraméterü modell. A térfüggő általánosításban a parciális időderiváltat az upper-convected deriválttal helyettesítettük. Az így kapott térfüggő Maxwell-modell az alábbi parciális differenciálegyenletekkel írható le [15, 13].

$$
\begin{aligned}
& \underline{\underline{\sigma}}_{j}+\frac{\eta_{j}}{k_{j}} \cdot \underline{\underline{\sigma}}_{j}=-\eta_{j} \cdot \underline{\dot{\gamma}}= \\
& \underline{\underline{\sigma}}_{j}=\frac{\partial \underline{\underline{\sigma}}_{j}}{\partial t}+\underline{\mathrm{v}} \cdot\left(\nabla \cdot \underline{\underline{\sigma}}_{j}\right)-\left[\underline{\underline{\sigma}}_{j} \cdot(\nabla \cdot \underline{\mathrm{v}})+(\nabla \cdot \underline{\mathrm{v}})^{T} \cdot \underline{\underline{\sigma}}_{j}\right] \\
& \underline{\underline{\sigma}}=\sum_{i=1}^{n} \underline{\underline{\sigma}}_{j},
\end{aligned}
$$


ahol $j$ a Maxwell eleme indexe.

Az így definiált UCM-modell a szokásos viszkoelasztikus viselkedésen túl képes számot adni a nyírás irányára merölegesen kialakuló feszültségkomponensröl (normal stress) is. Azonban továbbra is nyírási sebességtől független konstansa dinamikai viszkozitást ad.

\subsubsection{Upper-convected White-Metzner-modell}

A White-Metzer-modell, alkalmasan választott nyírási sebességtől függő viszkozitás paraméterek esetén, képes a dinamikai viszkozitás nyírási sebességtől való függését modellezni. Mivel a vizsgált szilikon olaj is ezen tulajdonsággal bír, a koncentrált paraméterü White-Metzer-modellt is általánosítanunk kell. A Maxwell-modell általánosításához hasonlóan, most is az upper-convected deriváltat alkalmaztuk. Az így kapott térfüggő White-Metzner-modell az UCM-modellnél megadott parciális differenciálegyenletekkel írható le, mindössze annyi változtatással, hogy a 2.34 egyenlet helyett az alábbi konstitúciós egyenletet kell használni [17].

$$
\underset{=\sigma_{j}}{\sigma_{j}}+\frac{\tilde{\eta}_{j}(\dot{\gamma})}{=} \cdot \underline{\underline{\sigma}}_{j}=-\tilde{\eta}_{j}(\underset{=}{\dot{\gamma}}) \cdot \underset{=}{\dot{\gamma}},
$$

ahol a modellalkotás feladata annak meghatározása, hogy $\tilde{\eta}_{j}$ konkrétan hogyan függ a $\underline{\underline{\dot{\gamma}}}$ tenzortól. 


\subsection{Végeselemes módszer (FEM)}

Az imént definiált térfüggő parciális differenciálegyenleteket valós körülmények között általában csak numerikus módszerekkel lehet megoldani. Egy lehetőség, ha végeselemes módszert (FEM, Finite Element Method) alkalmazunk a parciális differenciálegyenletek közelítő megoldásának meghatározására [49]. Lényege, hogy a fizikai rendszer geometriáját olyan kis elemekre osztjuk, amelyeken belül a keresett fizikai mennyiségek változásai elegendően kicsik. Ezek az elemek tipikusan háromszögek vagy négyszögek, amelyek kitüntetett pontjaiban (pl.: csúcsok, oldalfelező pontok, stb.) úgynevezett csomóponti változókként reprezentáljuk a fizikai mennyiségeket. A csomópontok között egyszerü függvényekkel interpoláljuk a keresett fizikai mennyiségeket, tipikusan első- vagy másodfokú polinomokkal, ezek az ún. alakfüggvények (shape functions). A megoldást azonban nem csak a csomópontokban próbáljuk minél pontosabban meghatározni, hanem az egész tartományban közelítőleg egyenletesen jó közelítésre törekszünk. Ezzel matematikai szempontból valójában egy variációszámítási problémát kapunk. Mivel ezt végülis diszkretizált módon hajtjuk végre, a FEM módszer nagy algebrai (végül általában lineáris) egyenletrendszerek megoldását igényli [49].

A jelenlegi végeselemes szoftverek többsége, úgy mint az általunk alkalmazott COMSOL szoftver is, automatikusan létrehozza a módszer alapját jelentő végeselemes hálót, a felhasználónak általában csak a finom részletek beállításával kell foglalkoznia. Ezzel kapcsolatban az 5.10 alfejezetben mutatunk konkrét példát saját eredményeink ismertetése során.

A térfüggő reológiai modelljeink helytől és időtől is függő parciális differenciálegyenlet rendszert alkotnak. Az egyik gyakran alkalmazott módszer az időfüggő probléma megoldására FEM esetén, hogy a helytől és időtől függő parciális differenciálegyenlet rendszert csak hely szerint diszkretizáljuk, így a csomóponti változókra vonatkozóan egy csak időtől függő közönséges differenciálegyenlet rendszert kapunk, amit valamilyen stabil, tipikusan implicit módszerrel szokás megoldani [49]. 
FEM szoftver használatának tipikus lépései:

- geometria megrajzolása/importálása CAD fájlból

- fizikai egyenletek kiválasztása/megadása

- anyagi jellemzők, paraméterek értékének megadása

- kezdeti- és peremfeltételek beállítása

- végeselemes háló létrehozása, minőségének ellenőrzése

- numerikus megoldás paramétereinek beállítása

- numerikus megoldás kiszámítása

- megoldás feldolgozása, ábrázolása, további fizikai mennyiségek kiszámítása 


\section{Célkitüzések}

Első lépésként a célom a reprezentánsnak választott szilikonolaj alapvető reológiai jellemzőinek minél pontosabb megmérése volt a Szegedi Tudományegyetemen hozzáférhető rotációs reométer segítségével, a lehető legszélesebb hőmérsékleti és nyírási sebesség, valamint frekvencia tartományban. Már ekkor kiderült, hogy ez a szilikonolaj egy nemlineáris viszkoelasztikus folyadék, ami feltehetőleg néhány olyan fontos reológiai szabálynak is eleget tesz, amely lehetővé tesz egy viszonylag egyszerü, fizikailag is értelmezhető koncentrált paraméteres reológiai modell felállítását.

A fentiek alapján célul tüztem ki a reometriai mérések kiterjesztését több irányba is. Egyrészt az alkalmazások szempontjából fontos célom volt, hogy a veszteségi és tárolási moduluszokat, illetve a belőlük kiszámítható lineáris viszkoelasztikus paramétereket minél szélesebb frekvencia tartományban meghatározzam. Ehhez végülis a Diffusing Wave Spectroscopy (DWS) módszer bizonyult járható útnak.

Mivel az úgynevezett Cox-Merz szabály teljesülése fontos szerepet játszott az általam tervezett nemlineáris viszkoelasztikus modellben, ezért fontos célom volt ennek érvényességét nagy pontossággal ellenőrizni minél szélesebb nyírási sebesség tartományban, amihez a dinamikai viszkozitásnak kapilláris viszkoziméterrel elvégzett pontos mérésére volt szükség, a megfelelő hőmérséklet tartományban.

A nemlineáris viszkoelasztikus tulajdonságok reometriai szempontból, tehát igazán jól mérhetően, a nagy amplitúdójú oszcillációs nyírási (LAOS) tesztek során jelennek meg. Ráadásul ezek a LAOS tesztek a motivációt nyújtó jármüipari együttmüködés szempontjából is fontos mérési adatokat szolgáltatnak. Fontos célom volt tehát ilyen mérések segítségével kísérletileg feltérképezni a reprezentáns szilikonolaj nemlineáris viszkoelasztikus viselkedését, valamint továbbfejleszteni a koncentrált paraméteres nemlineáris reológiai modellt úgy, hogy a LAOS tesztek eredményei is szimulálhatók legyenek.

A legfontosabb koncentrált paraméteres reológiai modelleknek különböző típusú ismert térfüggő általánosításai vannak, amelyekben az idő szerinti deriváltat egy alkalmasan megválasztott differenciáloperátorral kell helyettesíteni. Céljaim között szerepelt egy ilyen térfüggő általánosítás kidolgozása és szimulációs tesztelése is, utóbbira magának a reométerben zajló nyírási folyamatnak a szimulációja is rendkívül jó 
lehetőséget adott: bizonyos nemlineáris viszkoelasztkus folyamatok, mint pl. a Weissenberg-effektus, tisztázatlan mértékben befolyásolják a reométeres mérést. A térfüggő modell bonyolult parciális differenciálegyenletei miatt a szimulációt egy végeselemes szoftver segítségével terveztem végrehajtani. 


\section{Alkalmazott anyagok, eszközök, módszerek}

\subsection{Vizsgált anyag (PDMS)}

Az általunk vizsgált anyag az egyik legszélesebb körben használt szilíciumalapú szerves polimer a poli-dimetil-sziloxán (PDMS). A PDMS képlete: $\mathrm{CH}_{3}\left[\mathrm{Si}\left(\mathrm{CH}_{3}\right)_{2} \mathrm{O}\right]_{n} \mathrm{Si}\left(\mathrm{CH}_{3}\right)_{3}$, ahol $n$ az ismétlődő $\mathrm{SiO}\left(\mathrm{CH}_{3}\right)_{2}$ monomer egységek száma [50]. A poli-dimetil-sziloxán térkitöltő modelljének egy részletét a 11. ábra mutatja. Jól látható, hogy lineáris láncmolekulák alkotják a folyadékot. A szilikonolajok dinamikai viszkozitását csak a láncmolekulák hossza $(n)$ szabja meg. Minél nagyobb a minta molekulatömege (minél nagyobb $n$ ) annál nagyobb a minta viszkozitása [15].

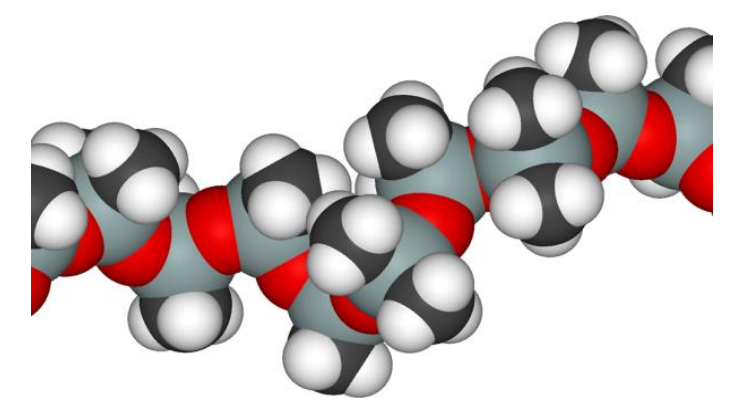

11. ábra: A poli-dimetil-sziloxán térkitöltő modelljének egy részlete

A szilikonolajokat igen széles körben alkalmazzák az alap- és alkalmazott kutatástól kezdve a szerteágazó ipari felhasználásig [51, 52]. A PDMS-t különleges reológiai viselkedése miatt gyakran használják a polimerkémiában és az anyagtudományokban: mátrix folyadékként (matrix fluid) szuszpenziókban [53-56] és kolloid diszperziókban, illetve polimer blendek komponenseként [58, 59]. Előszeretettel alkalmazzák új reologiai elméletek [60] és újszerü mérési eljárások és mérőmüszerek [61] hitelesítésére tesztanyagként. Egyes reométergyártó vállalatok a készülékek mindenkori kalibráláshoz használják a szilikonolajat [62]. Ahhoz, hogy a szilikonolajokat megfelelően tudjuk az alapkutatásban és az ipari alkalmazásban felhasználni, nélkülözhetetlen, hogy megismerjük az anyag részletes reológiai tulajdonságait mind a lineáris, mind a nemlineáris viszkoelasztikus tartományban. A nagy viszkozitású PDMS olajok nemlineáris viszkoelasztikus és nagyfrekvenciás lineáris viszkoelasztikus leírása meglehetősen hiányos. 
A korábbi poli-dimetil-sziloxán reológiai vizsgálatáról szóló cikkek többsége a 10 50 Pas, vagy ez alatti dinamikai viszkozitású olajokról szól [52, 63]. Igen kevés tanulmány foglalkozik sokkal magasabb viszkozitású szilikonolajokkal [64, 65]. A nagy viszkozitású szilikonolajok pszeudoplasztikus viselkedésével foglalkozó részletes elemzés [66] valamint a relaxációs időről szóló átfogó tanulmány [67] jól leírja a hagyományos rotációs reométer mérési tartományán belül az anyagra jellemző reológiai tulajdonságokat. Egy ultrahangalapú módszer segítségével vizsgálták a 100 és 500 Pas dinamikai viszkozitású minták nagyfrekvenciás viselkedését, és azt találták, hogy a $10^{6}-10^{7} \mathrm{~Hz}$ frekvencia tartományban a tárolási és veszteségi modulusz görbék másodszor is keresztezik egymást [68].

Jelen dolgozatban az AK1.000.000. (Wacker Chemie) szilikonolaj reológiai mérésével és modellezésével kapcsolatos vizsgálataink eredményeit mutatom be. A mintának igen nagy, megközelítőleg 1000 Pas a viszkozitása $25^{\circ} \mathrm{C}$-on. A vizsgált anyag egyedi reológiai tulajdonságokkal rendelkezik, ezért egyes reométergyártó vállalatok a készülékek kalibráláshoz használják. A jármüiparban elsősorban lengéscsillapító anyagként alkalmazzák, speciális felhasználási területe a dugattyús motorok szabad végén elhelyezkedő torziós viszkózus lengéscsillapító, ahol a szükséges nagy viszkozitást a szilikonolaj biztosítja. Az általam választott AK1.000.000 szilikonolaj jól reprezentálja a 200 és 2000 Pas viszkozitás közé eső szilikonolajokat, amelyek mindegyike nemlineáris viszkoelasztikus anyag.

\subsection{Mérések rotációs reométerrel}

Anton Paar Physica MCR 101 típusú reométerrel [69] végeztük a rotációs és oszcillációs méréseket. Egy ilyen készülékröl készített képet mutat a 12. ábra. Ez egy modern műszer, amely már légcsapágyat tartalmaz, így a mérőtest forgásakor fellépő súrlódási veszteség igen kicsi, ezáltal lehetővé teszi a pontos mérést a rotációs és oszcillációs vizsgálatok során. A reométer mérési frekvenciáját a $0.01-100 \mathrm{~Hz}$ tartományban, míg a hőmérsékletet 0 és $120^{\circ} \mathrm{C}$ fok között tudjuk változtatni.

Az MCR 101 úgynevezett nyírófeszültség-vezérelt reométer: a mérőgeometria forgó részét forgató elektromos motor áramerősségének pillanatnyi értékéből számítja ki a reométer a mintára jutó nyírófeszültséget, ugyanakkor ezt az áramot úgy szabályozza, hogy 
a motorral azonos tengelyre szerelt optikai szögelfordulás-szenzor adatai alapján az elöírt időfüggésű nyírás valósuljon meg.

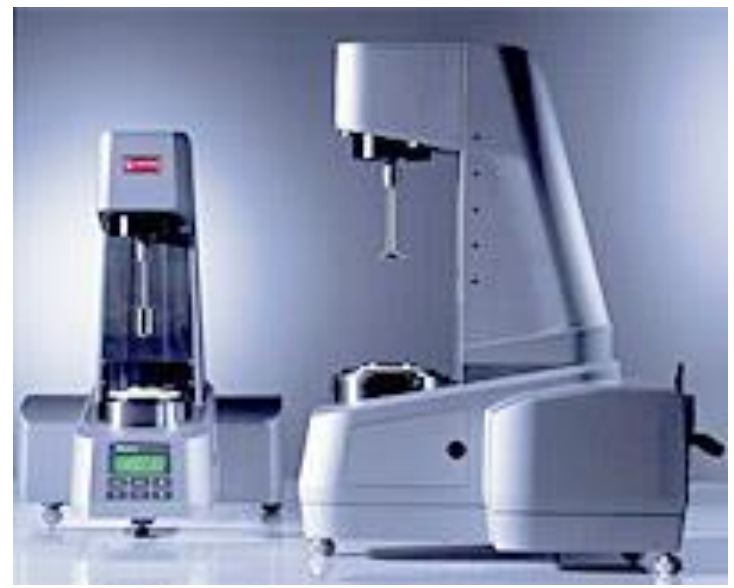

12. ábra: Anton Paar Physica MCR 101 típusú reométer

A régebbi gyártású hagyományos reométereknél (pl.: MCR 101) nem lehetett közvetlenül a mért időfüggő nyírófeszültségi jelhez hozzáférni, csak a reométer szoftvere (MCR 101-es reométer szoftvere: Rheoplus) által megadott reológiai paraméterekhez, így a program által számolt tárolási és veszteségi modulusokhoz is, amelyek a már nemlineáris estekben a 2.18-as képlet alapján a $\mathrm{G}_{1}{ }_{1}$ és $\mathrm{G}^{\prime}{ }_{1}$ mennyiségeknek felelnek meg. Számos reométernél a BNC portokon keresztül hozzá lehet férni a nyers beállított szögelfordulás, szögsebesség és mért nyomaték időfüggő jelekhez, ahhoz azonban, hogy ezekből a jelekből a reológiában használt időfüggő nyírás; nyírási sebesesség és nyírófeszültségi értékeket megkapjuk, szükség van mind a mérőfej, mind a mérőműszer tényleges ismeretére, amelyet a gyártó érthető üzleti okokból nem ad meg.

A nemlineáris reológiai térnyerésének köszönhetően az utóbbi öt évben a reométergyártók új termékeinél (pl.: Anton Paar Physica MCR 702; Malvern Kinexus Pro) már a szoftveren keresztül hozzáférhetünk a megvalósuló időfüggő nyírás és a mért nyírófeszültség jelekhez. A legújabb szoftverek már több, a LAOS tesztek elemzéséhez használható reológiai módszert is tartalmaznak (pl.: FT reológia; Nyírófeszültségszétbontás).

A szilikonolaj nemlineáris viszkoelasztikus tulajdonágainak leírásához szükséges LAOS teszteket a legújabb Anton Paar Physica, MCR 702-es reométeren mértük. Az új sorozathoz egy új szoftvert is kifejlesztett a gyártó, amely a RheoCompass nevet kapta. A szoftverből mind a bemenő időfüggő nyírás, kimenő időfüggő nyírófeszültségi jel, mind az FT reológiai és az Ewoldt-paraméterek hozzáférhetőek. 


\subsubsection{Mérési eljárások}

A mérőműszerekkel két üzemmódban mérhetünk: rotációs és oszcillációs módban. A legalapvetőbb rotációs mérések az egyszerü nyírási tesztek.

Egyszerü nyírási tesztek: lineárisan növeljük a nyírási sebességet, vagy a nyírófeszültséget, miközben mérjük a másik mennyiséget.

Az oszcillációs tesztek lényege, hogy tisztán szinuszosnak választjuk a nyírás vagy a nyírófeszültség jelet, miközben a másik jelet mérjük. Két alapvető változata az amplitúdó-pásztázó és a frekvencia-pásztázó tesztek.

Amplitúdó-pásztázó tesztek: A tisztán szinuszos bemenő jel amplitúdóját változtatjuk, miközben vizsgáljuk a tárolási és a veszteségi modulusz alakulását. Ezt a módszert alkalmazzák a lineáris és nemlineáris viszkoelasztikus tartomány elkülönítésére.

Megjegyzés: LAOS teszteken a nemlineáris viszkoelasztikus tartományban mért frekvencia és amplitúdó függő kimenő nyírófeszültség jelek mérését értjük.

Frekvencia-pásztázó tesztek: A tisztán szinuszos bemenő jel frekvenciáját változtatjuk, miközben vizsgáljuk a tárolási és veszteségi modulusz alakulását. Tipikusan kis amplitúdójú periodikusan változó nyírást alkalmazunk, hogy az anyag lineáris viszkoelasztikus tulajdonságait leírhassuk.

\subsubsection{Mérőrendszerek}

A rotációs és oszcillációs mérésekhez többfajta mérőgeometria is használható. A 13. ábra mutatja a legalapvetőbb mérőrendszereket. A méréseinkhez legtöbbször a $10 \mathrm{~mm}$ belső-henger átmérőjü koncentrikus henger (CC10) geometria, illetve bizonyos estekben a 25 mm átmérőjü kúp-lap (CP25) geometria bizonyult optimálisnak, ezért ezeket használtuk. 


\subsubsection{Koncentrikus henger mérögeometria}

A koncentrikus henger (concentric cylinder) geometriát a 13.(a) ábra mutatja. A minta a külső (pohár) és belső henger (fej) között helyezkedik el. A belső hengert forgatjuk, miközben a külső hengert rögzítjük. Egyenletes, lamináris, izoterm áramlási kép alakul ki [15]. Ha a külső és belső henger közötti résméret megfelelően kicsi $\left(R_{i} / R_{a}<0.97\right)$, akkor a mintában a nyírási sebesség és nyírófeszültség állandónak tekinthető [70].

\section{Elönyei:}

- állandó nyírási sebesség

- $\quad$ nagy mérőfelület; nagy pontosság

\section{Hátrányai:}

- nagy viszkozitású anyag betöltése nehéz (buborékok megjelenése)

- nagy a mérőfej tehetetlenségi nyomatéka

- normális irányú nyírófeszültséget nem képes mérni

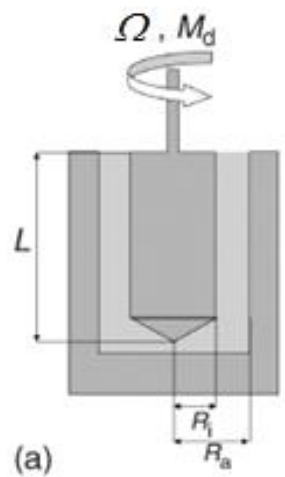

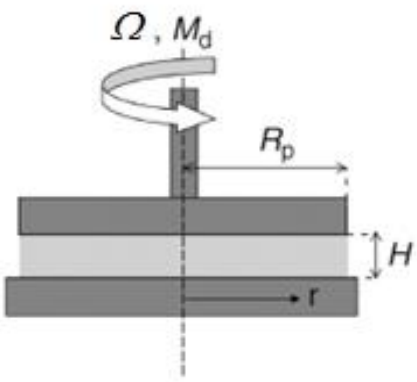

(b)

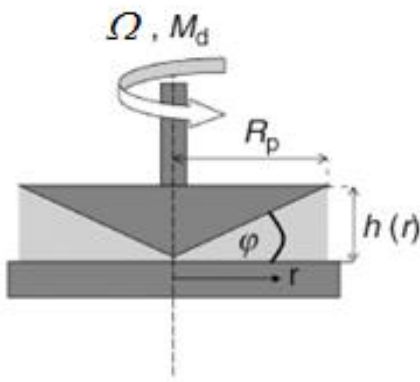

(c)

13. ábra: A legalapvetőbb mérőgeometriák szerkezeti vázlata: koncentrikus henger (a), lap-lap (b) és kúp-lap (c) geometria

\subsubsection{Lap-lap mérógeometria}

A lap-lap (parallel plate) geometriát a 13.(b) ábra mutatja. A minta a két párhuzamos egymástól $H$ távolságban levő lap között helyezkedik el $[15,71]$. Az alsó lap rögzített, miközben a felső lap forog. Szintén egyenletes, lamináris, izoterm áramlási kép alakul ki, azonban a nyírási sebesség nem állandó $\left(\dot{\gamma}(r)=\frac{\Omega \cdot r}{H}\right)$. 


\section{Elönyei:}

- egyszerü mintabetöltés

- a minta falon való megcsúszása (wall slip) a beállított $H$ távolságtól függ, így az különböző mérési távolságok beállításával kiküszöbölhető

- normális irányú nyírófeszültség mérésre alkalmas geometria

\section{Hátrányai:}

- a nyírási sebesség nem állandó

- centrifugális hatások (centrifugal effects) megjelenése

\subsubsection{Kúp-lap mérögeometria}

A kúp-lap (cone-plate) geometriát a 13.(c) ábra mutatja. A minta egy forgó kúp és egy rögzített lap között helyezkedik el $[15,71]$. Szintén egyenletes, lamináris, izoterm áramlási kép alakul ki. A leggyakrabban alkalmazott geometria, hiszen a nyírási sebesség az egész mintában állandó $\left(\dot{\gamma}(r)=\frac{\Omega}{t g(\alpha)}\right)$.

\section{Elönyei:}

- egyszerü mintabetöltés

- állandó nyírási sebesség

- normális irányú nyírófeszültség mérésre alkalmas geometria

\section{Hátrányai:}

- magas nyírási sebesség értékeknél a minta felmászik a kúpos mérőfejre (shear fracture)

- centrifugális hatások (centrifugal effects) megjelenése

Itt jegyezzük meg, hogy a kúp-lap geometria valójában egy csonka kúp azért hogy felső lap ne érintkezzen az alsó lappal.

\subsection{Kapilláris mérések}

Kapilláris méréseket végeztünk az anyag nagy nyírási sebességhez tartozó viszkózus tulajdonságainak leírására. Az eszköz müködésének alapelve az, hogy egy vékony kapilláris csövön keresztül állandó sebességgel átáramoltatja a vizsgálandó 
folyadékot, eközben méri az áramlás fenntartásához szükséges nyomást. Tipikusan úgy szokták megvalósítani, hogy mintát egy olyan hengerbe töltjük, amelynek egyik végén egy mozgatható dugattyú, másik végén pedig egy $L$ hosszúságú és $D$ átmérőjü kapilláris található [15]. A dugattyút egy beállított sebességgel elkezdjük mozgatni, így az anyagban létrejövő nyomás hatására az anyag elkezd kifolyni a kapillárison keresztül. Mérve a kapilláris belépésénél a nyomást, matematikai számításokkal a nyírási sebesség és nyírófeszültség megkapható. A kapilláris reométerben kialakult áramlási kép nem homogén, számos korrekciót kell alkalmazni, hogy a mért, látszólagos adatokból valódi, elemezhető adatokat nyerjünk. A nyomásmérésnél is számos probléma merül fel, ebből a legjelentősebb az úgynevezett belépési (Bagley) korrekció [72]. A kapillárisba való belépésnél nyomásesés következik be, ez különböző $D / L$ méretü kapillárisokon történő mérésekkel figyelembe vehető.

Mi egy Göttfert Rheograph 25 típusú kapilláris reométerrel mértünk (14. ábra). A müszer képes egészen nagy nyírási sebesség tartományban $\left(10^{5} 1 / \mathrm{s}\right)$ is a minta viszkozitásának megadására. Ez a müszer egyszerre két különböző $D / L$ arányú kapillárison nyomja át az olajat, így szoftver a szükséges Bagley korrekciót automatikusan elvégzi. Az inhomogén áramlás során mért adatok automatikus korrekcióját is elvégzi a szoftver.

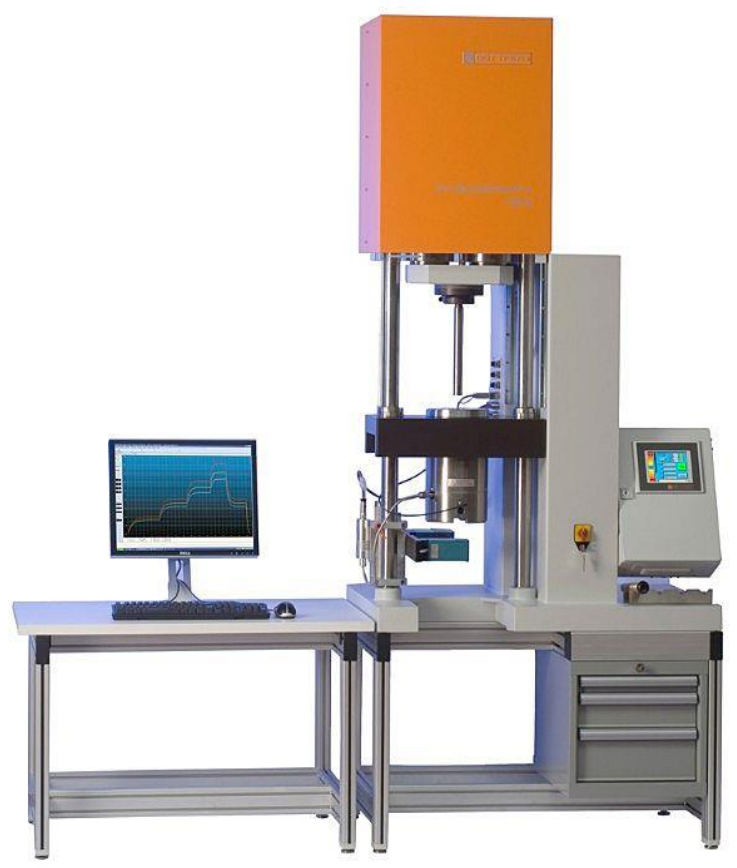

14. ábra Göttfert Rheograph 25 típusú kapilláris reométer 


\subsection{DWS mérések}

A Diffusing Wave Spectroscopy egy napjainkban már kiforrottnak tekinthető módszer a folyadékok nagyfrekvenciás reológiai tulajdonságainak vizsgálatára [23, 24]. A módszer tömör leírását a 2.4.3 alfejezet tartalmazza. Az átlátszó anyagoknál, mint pl. a PDMS, a fény szóródását mesterségesen kell előidézni, jellemző módon nyomjelző részecskéket kell eloszlatni a mintában. Tipikus nyomjelző részecskék a gumi, szilicium és a titán-dioxid részecskék. A PDMS hidrofób tulajdonsága erősen korlátozza azokat a választható nyomjelző részecskéket, amelyeket homogénen el lehet keverni a mintában, és elegendően nagy szórást eredményeznek. A szilikonolaj fényszórásos vizsgálatához a titándioxid nyomjelző részecskék bizonyultak a legmegfelelőbbnek. Ahhoz, hogy a hidrofil nyomjelző részecskéket egyenletesen tudjuk eloszlatni a nagy viszkozitású hidrofób szilikonolajban, társoldószert használtunk. A részecskéket Span ${ }^{\circledR} 80$ (Fluka) felületaktív anyagot tartalmazó etil-acetát (Sigma) oldatban elkevertük. A felületaktív anyag a hidrofób részecskefelület kialakítás miatt volt szükséges. A többlet felületaktív anyag eltávolítása után, az oldott részecskéket elkevertük a szilikonolajban. Az etil-acetát oldószer lecsökkentette a szilikonolaj viszkozitását annyira, hogy egyenletesen el tudtuk keverni a nyomjelző részecskéket. Az így keletkezett keveréket a mérőcellába (vastagság $L=5 \mathrm{~mm}$ ) helyeztük. A cellát négy napig szárítottuk $85^{\circ} \mathrm{C}$-on, hogy az etil-acetátot teljesen elpárologtassuk a mintából. A nyomjelző részecskék végső koncentrációja körülbelül 2.5 wt\%-nak adódott. LS Spektrométerrel (LS Instruments) meghatároztuk a Span ${ }^{\circledR}$ által stabilizált nyomjelző részecskék hidrodinamikai átmérőjét (200 $\pm 80 \mathrm{~nm})$.

$\mathrm{Az}$ egyenletesen eloszlatott, jól definiált átlagos hidrodinamikai átmérővel rendelkező nyomjelző részecskéket tartalmazó mintán már elvégezhettük a DWS méréseket. A nagy viszkozitású szilikonolajat DWS ReserchLab (LS Instruments) készülékkel vizsgáltuk transzmissziós módban. A készülék tartalmaz egy szoftvercsomagot, amely elvégzi a szükséges mikroreológiai számításokat. A szilikonolaj erősen elasztikus jellege korlátozza a frekvencia tartományt, amelyen belül a tárolási és veszteségi modulusok pontosan lemérhetőek. A mérések azt mutatták, hogy 10 és $10^{5} \mathrm{rad} / \mathrm{s}$ körfrekvencia értékek között kapunk pontos eredményt. 


\subsection{Matematikai és numerikus szimulációs szoftverek}

A mérésekre illesztett és később számos megfontolás alapján meghatározott konstitutív egyenletek megoldását többfajta szimulációs környezetben valósítottam meg.

A koncentrált paraméterü (,nulldimenziós”) modelleket tartalmazó szimulációkat a Wolfram Mathematica és a Matlab [73] programok segítségével végeztem el. Az általam definiált konstitúciós egyenletek olyan közönséges differenciálegyenletek, amelyeket csak numerikus módon lehet megoldani. Ezért egy olyan programkódot készítettünk, amelyet a következő módon müködik: beállítjuk a kívánt nyírási sebesség jelet, a program megoldja a konstitúciós egyenleteket, majd meghatározza a nyírófeszültség jelet. A program a bemenő nyírási sebesség és kimenő nyírófeszültség jelből kiszámolja a megfelelő lineáris és nemlineáris viszkoelasztikus jelleget leíró mennyiségeket. Ezt a programot tehát egy „virtuális reométernek” is tekinthetjük.

A koncentrált paraméterü konstitúciós egyenlet általánosításával kapott térfüggő parciális differenciálegyenlet-rendszert tartalmazó modellek megoldásához, bonyolultságuk miatt, numerikus módszerre volt szükség. A végeselemes módszerek (FEM) jól alkalmazhatók ilyen célra, ezért a Comsol szoftvert használtam. Ez egy modul rendszerü, rendkívül széles körben használható végeselemes szimulációs szoftver, amely lehetővé teszi azt is, hogy a szokásos fizikai folyamatokat leíró egyenleteket kiegészítsük további differenciálegyenletekkel, mint pl. a térfüggő konstitúciós egyenletek. 


\section{Eredmények}

\subsection{Szilikonolaj tisztán viszkózus tulajdonságainak vizsgálata}

Első lépésben mindig a vizsgált anyag viszkózus szempontból vett osztályozását kell meghatározni, vagyis el kell dönteni, hogy a minta dilatáló, pszeudoplasztikus vagy esetleg newtoni folyadékként viselkedik-e. Az AK1.000.000. típusú szilikonolaj minta tisztán viszkózus tulajdonságait egyszerü nyírási tesztekkel vizsgáltam (simple shear flow).

A nyírási sebesség által vezérelt egyszerü nyírási teszteket $25^{\circ} \mathrm{C}, 40^{\circ} \mathrm{C}, 60^{\circ} \mathrm{C}$ és $80{ }^{\circ} \mathrm{C}$ hőmérsékleten végeztem. Az egyszerü nyírási teszteket egy Physica MCR-101 (Anton Paar) rotációs reométerrel és CC10-es mérőfejjel hajtottam végre a Szegedi Tudományegyetem Gyógyszertechnológiai Intézetében. Minden hőmérsékleten új mintával végeztem a méréseket. A mérések eredményeit szemlélteti a 15. ábra. A mért viszkozitás értékeket körrel, míg a mért nyírófeszültség értékeket négyzettel ábrázoltuk.

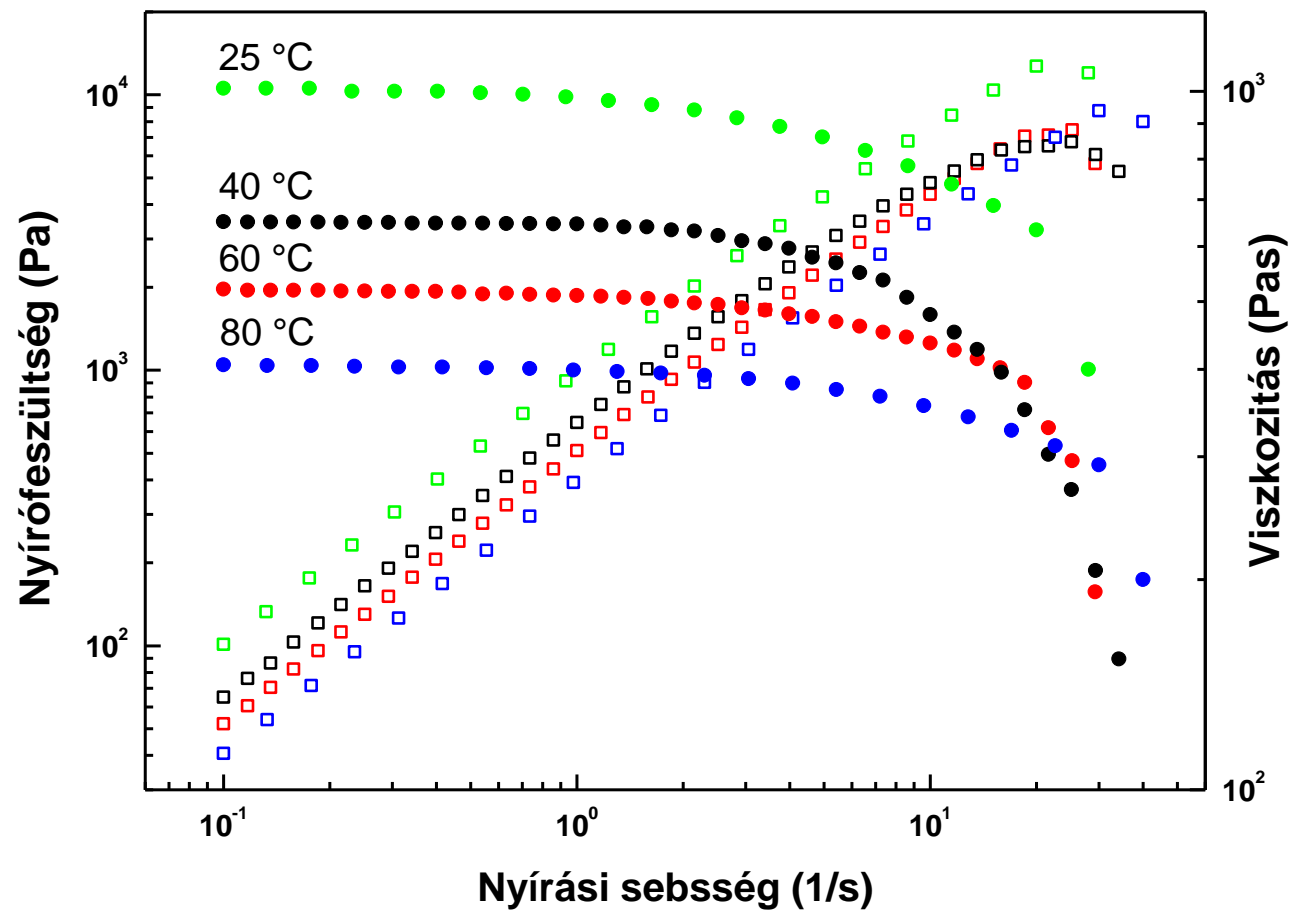

15. ábra: Különböző hőmérsékleteken mért egyszerű nyírási tesztek eredményei. A mért nyírófeszültségeket az üres négyzetek, míg a dinamikai viszkozitás értékeket a teli körök jelölik.

A rotációs reométerrel mért nyírási tesztek (flow curve) azt mutatják, hogy a szilikonolaj az összes mért hőmérsékleten nem-newtoni folyadékként viselkedik: a nyírási sebességet növelve csökken a viszkozitása, azaz pszeudoplasztikus (shear thinnig) folyadék, amely összhangban van a várt eredménnyel [66]. Az ábráról leolvasható, hogy az 
összes vizsgált hőmérsékleten kb. 20 1/s nyírási sebességnél a mért nyírófeszültség csökkenni kezd, amely egy drasztikus esést eredményez a mért viszkozitás értékekben. Ez a nem kívánt effektus az anyag viszkoelasztikus jellegének egyik - az irodalmi áttekintésben bemutatott Weissenberg-effektusnak a - következménye. A mintában a nyírás hatására ébredő, a forgástengellyel párhuzamos nyomófeszültség értéke ekkor már elegendő ahhoz, hogy a mintát kinyomja a mérőgeometriából. A 15. ábrán jól látszik, hogy kis nyírási sebességek esetén a minta viszkozitása állandónak tekinthető, és jó közelítéssel megegyezik az anyagra jellemző 0 nyírási sebességnél mérhető dinamikai viszkozitás (zero shear viscosity) értékével. A gyártó adatai szerint a vizsgált nagy viszkozitású szilikonolaj dinamikai viszkozitása $25^{\circ} \mathrm{C}$-on 1000 Pas. A 15 . ábráról leolvasható a minta mért dinamikai viszkozitása $25^{\circ} \mathrm{C}$-on, ami 1010 Pas. A mért érték nagyon közel esik a gyártó által megadott értékhez. Összhangban a várakozással az alacsonyabb hőmérsékleti értékekhez tartozó dinamikai viszkozitás értékek egyre növekszenek. A viszkozitás erős hőmérsékletfüggését az is mutatja, hogy már $60^{\circ} \mathrm{C}$-os hőmérsékleten a minta viszkozitása a $25^{\circ} \mathrm{C}$-on mérhető viszkozitás felére csökken. Tehát a pontos hőmérsékletszabályozás nagyon fontos, különben a minta reológiai elemzésénél nem lehetne elkülöníteni, hogy tapasztalt viselkedés magának az anyagnak, vagy a nem megfelelően szabályozott hőmérsékletnek köszönhető.

Egy fontos megjegyzés, hogy a mintát sokkal könnyebb magas hőmérsékleteken a mérőedénybe betölteni, hiszen ekkor sokkal jobban folyik (kisebb a dinamikai viszkozitása) a szilikonolaj, valamint a betöltés során a mintába jutó légbuborékok is könnyebben távoznak a mintából. Ezért a legtöbb mérést $60^{\circ} \mathrm{C}$-os hőmérsékleten végeztük. 


\subsection{Rotációs reométerrel mért lineáris viszkoelasztikus jellemzők}

A vizsgált AK1.000.000. típusú szilikonolaj nemlineáris viszkoelasztikus tulajdonsággal rendelkezik, ezért először amplitúdó-pásztázó méréssel meghatároztam a lineáris és nemlineáris viszkoelasztikus tartományt. A nyírásvezérelt amplitúdó-pásztózó méréseket $\omega=[1,2,5,10,20,50100] \mathrm{rad} / \mathrm{s} \quad$ körfrekvencia értékeknél, $\gamma_{0}=[0.1,100]$ nyírási amplitúdó intervallumban, dekádonként 6 pontban, $60^{\circ} \mathrm{C}$ hőmérsékleten végeztem. A mérésekhez a CC10-es geometriát használtam. Minden egyes mérést új mintával végeztem, hogy az esetleges belső, mikroszerkezeti, anyagi változások ne befolyásolják a mérést. Az amplitúdó-pásztázó reometriai mérések során egy Physica MCR-101 (Anton Paar) rotációs reométert alkalmaztam.

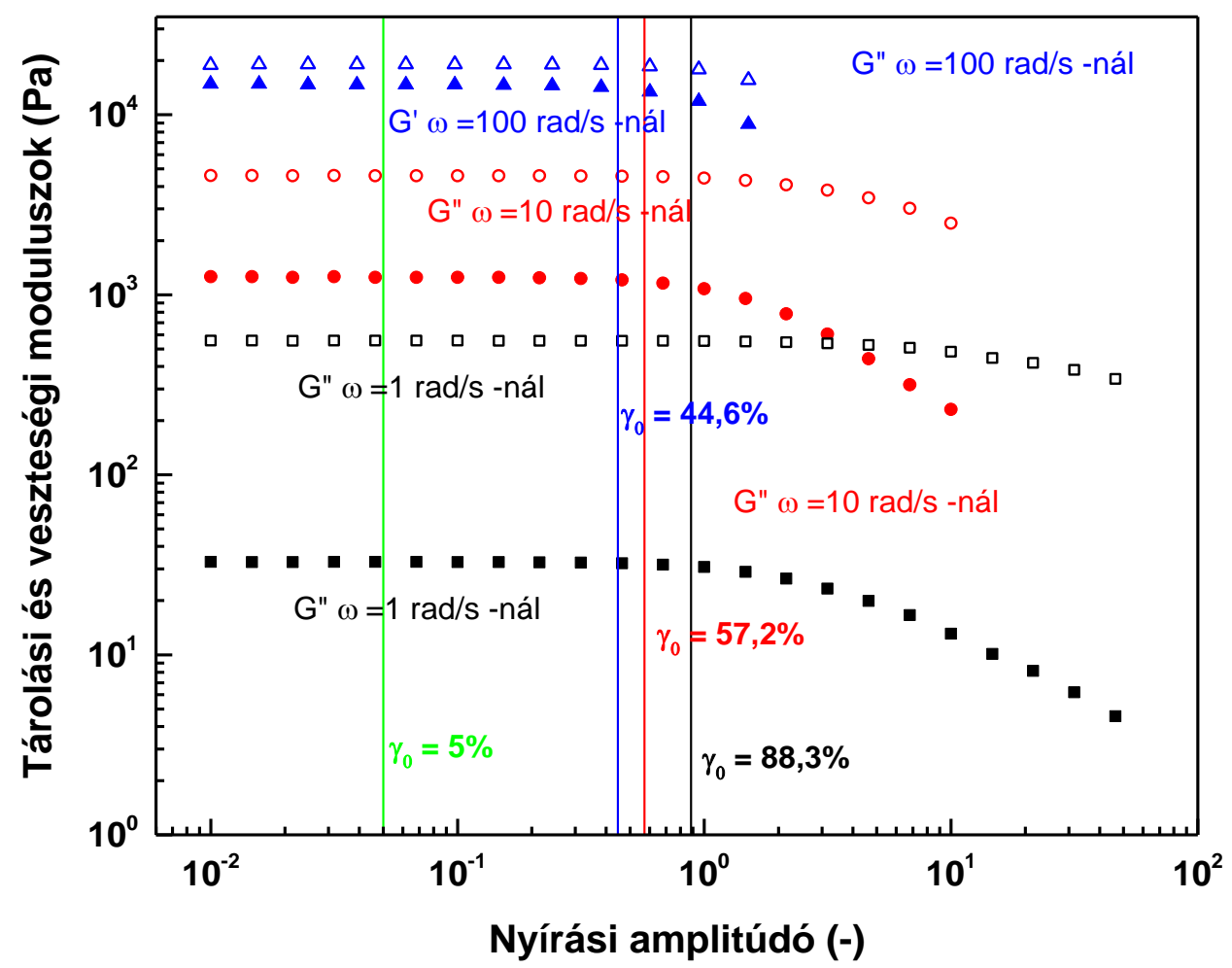

16. ábra: Különböző körfrekvencia értékeknél $(\omega=[1,10,100] \mathrm{rad} / \mathrm{s})$ mért amplitúdó-pásztázó mérések eredményei a nyírási amplitúdó függvényében. A tárolási moduluszokat a teli, míg a veszteségi moduluszok az üres szimbólumok jelzik. A függőleges vonalak a lineáris viszkoelasztikus tartomány határát jelölik a különböző körfrekvencia értékekre. A zöld függőleges vonal a frekvencia-pásztázó teszteknél alkalmazott nyírási amplitúdót jelöli.

A könnyebb átláthatóság kedvéért a 16 . ábrán csak az $\omega=[1,10,100] \mathrm{rad} / \mathrm{s}$ körfrekvencia értékekhez tartozó amplitúdó-pásztázó tesztek eredményeit ábrázoltam. Csak azok a mérési pontok jelenítettem meg, ahol a mérés még megbízható eredményt adott. Az ábráról látható, hogy a körfrekvencia növekedésével ez egyre kevesebb pontot jelent, ennek oka az, hogy a vizsgált szilikonolaj a Weissenberg-effektus hatására 
'kimászik' a mérőtérfogatból, és így már nem ad megbízható eredményt. A tárolási moduluszokat telt, míg a veszteségi moduluszokat üres szimbólumokkal jelöltük. A tárolási és veszteségi moduluszok kis nyírási amplitúdóknál állandóak maradnak, míg az amplitúdó növelésével csökkenni kezdenek. A lineáris viszkoelasztikus tartomány határát ott szokás meghúzni, ahol a tárolási és veszteségi modulusz értékek a kezdeti értékük 95\%ra csökkenek. A 16. ábrán függőleges vonallal jelöltem a különböző körfrekvenciaértékekhez tartozó lineáris viszkoelasztikus tartomány határát. Jól látszik, hogy a tárolási modulusz szabja meg ezt a kritikus nyírási amplitúdó értéket. A veszteségi modulusz értékek, csak ennél magasabb nyírási amplitúdó értékeknél kezdenek el csökkenni, ráadásul a csökkenés mértéke is kisebb. Minél nagyobb a nyírás körfrekvenciája, annál kisebb a kritikus nyírási amplitúdó, vagyis a nemlineáris viszkoelasztikus tartományt hamarabb elérjük.

A szilikonolaj lineáris viszkoelasztikus tulajdonságainak meghatározására, olyan kis nyírási amplitúdójú (SAOS) frekvencia-pásztázó teszteket kell végezni, ahol az alkalmazott nyírási amplitúdó az összes mérhető körfrekvencia esetén a kritikus tartományon belül marad. A nyírás amplitúdóját 5\%-nak választott, amely majdnem egy nagyságrenddel kisebb, mint a $\omega=100 \mathrm{rad} / \mathrm{s}$ körfrekvencia-értékekhez tartozó kritikus nyírási amplitúdó érték $(5 \%<<44,6 \%)$. A frekvencia-pásztázó méréseket $\omega=[0.628,628]$ körfrekvencia intervallumban, dekádonként 10 pontban, $60^{\circ} \mathrm{C}$ hömérsékleten végeztem. A 17. ábrán kétszer logaritmikus skálán mutatom be a kapott tárolási és veszteségi moduluszokat valamint a komplex viszkozitás abszolút értékét a körfrekvencia függvényében. A reológiai alapmennyiségek között több nagyságrendnyi különbség van, így a log-log ábrázolás az elterjedt a mennyiségek bemutatására. A mért tárolási modulusz értékeket négyzettel, a veszteségi modulust körrel, a komplex viszkozitás abszolút értékét pedig háromszöggel jelöltem. A tárolási és veszteség modulusz $\omega_{\mathrm{CO}}=208 \mathrm{rad} / \mathrm{s}$ értéknél metszi egymást, ezt a metszéspontot keresztezési körfrekvenciának hívják (crossover angular frequency). A keresztezési körfrekvenciánál alacsonyabb körfrekvencia értékekre a veszteségi moudulusz a domináns $\left(G^{\prime} \gg G^{\prime}\right)$, ez azt is jelenti, hogy lassú deformációkra a minta tökéletes folyadékként viselkedik, azaz a minta az összes energiát disszipálja. A keresztezési körfrekvencia felett a tárolási modulusz nagyobb, mint a veszteségi $\left(G^{\prime}<G^{\prime}\right)$, ilyenkor az anyag elasztikus (szilárd test) jellege erősebb, mint a viszkózus (folyadék) jellege, vagyis a minta több energiát képes tárolni, mint disszipálni. 


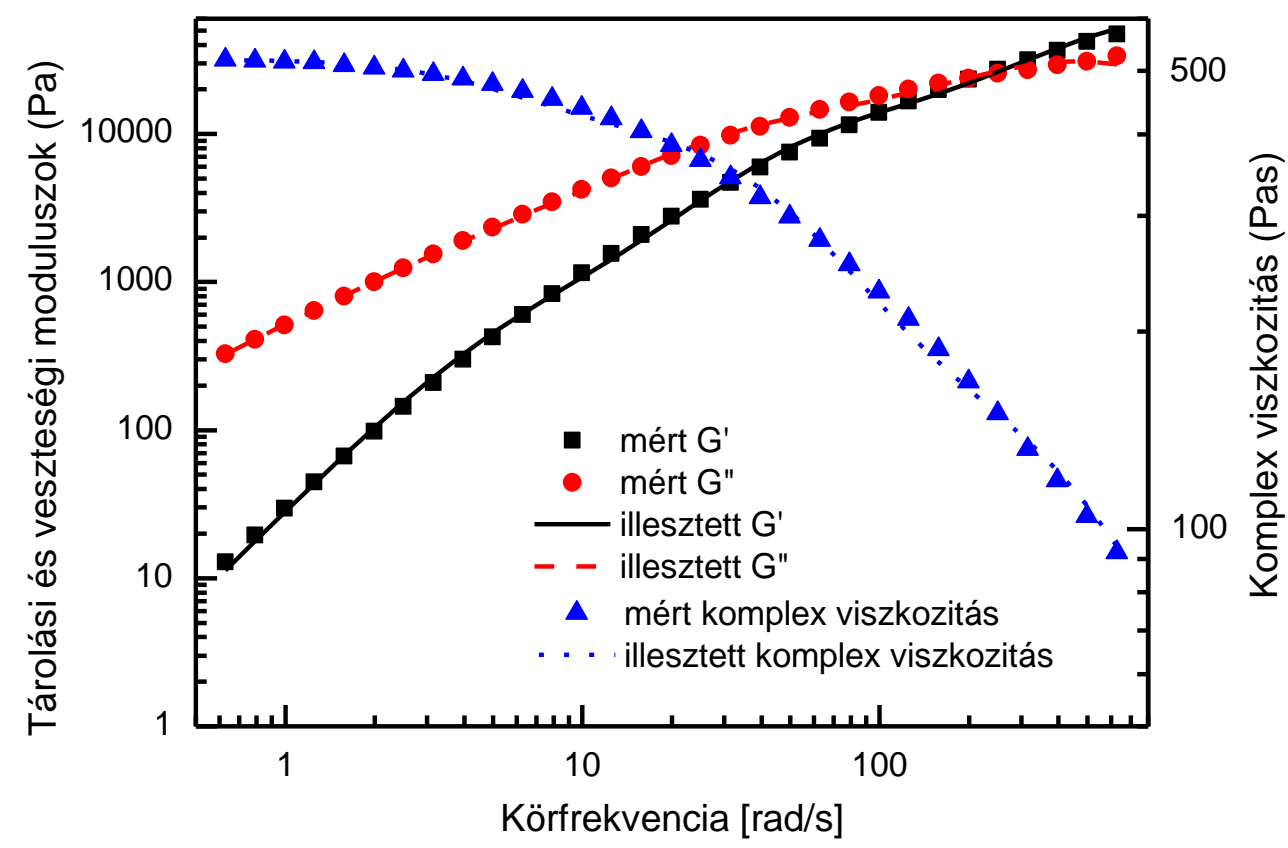

17. ábra: A $60^{\circ} \mathrm{C}$ hőmérsékleten mért tárolási (piros kör), veszteségi moduluszok (fekete négyzet) és komplex viszkozitás abszolút értéke (kék háromszög) a körfrekvencia függvényében. Valamint az adatokra illesztett háromelemü lineáris Maxwell-modell alapján számolt értékek (vonalak) a körfrekvencia függvényében.

Amint azt az irodalmi áttekintésben említettük, bármely anyag a lineáris viszkoelasztikus tartományban leírható egy $n$ elemü Maxwell-modellel, azaz $n \mathrm{db}$. relaxációs modulusz $k_{i}$ (elasztikus tulajdonságot leíró mennyiség) és $n$ db viszkozitás $\eta_{i}$ (viszkózus tulajdonságot leíró mennyiség) paraméterrel. Az illesztéshez olyan Maxwell paramétereket kerestem, amelyre a mért és számolt adatok közötti négyzetes eltérés minimális. Így a minimalizálandó célfüggvény a következőképp definiálható [15]:

$$
O=\sum_{i=1}^{n}\left[\left(\frac{G^{\prime}\left(\omega_{i}\right)-G_{\text {modell }}^{\prime}\left(\omega_{i}\right)}{G^{\prime}\left(\omega_{i}\right)}\right)^{2}+\left(\frac{G^{\prime \prime}\left(\omega_{i}\right)-G_{\text {modell }}^{\prime \prime}\left(\omega_{i}\right)}{G^{\prime \prime}\left(\omega_{i}\right)}\right)^{2}\right],
$$

ahol $G^{\prime}\left(\omega_{i}\right) ; G^{\prime \prime}\left(\omega_{i}\right)$ a mért tárolási és veszteségi moduluszok $\omega_{i}$ körfrekvencia értéknél. $G^{\prime}{ }_{\text {model }}\left(\omega_{i}\right) ; G^{\prime \prime}{ }_{\text {model }}\left(\omega_{i}\right)$ pedig a Maxwell-modell alapján számolt (2.14 és 2.15 egyenletek) tárolási és veszteségi moduluszok $\omega_{i}$ körfrekvencia értéknél. Az illesztésnél vigyázni kell, hogy megfelelő számú elemmel illesszük a mért adatokat. Nyílván túl kevés elem esetén nem elég pontos az illeszkedés. Habár $n$ növelésével $\min (O)$ csökken, oda kell figyelni, hogy az alkalmazott több elemmel lehet, hogy már csak magát a mérési hibákat illesztjük meg.

A mért adatokat különböző elemszámú Maxwell-modellekkel illesztettem meg (2.14 és 2.15 egyenletek). A $2 n$ paraméter ( $n$ viszkozitás és $n$ elasztikus paraméter) 
meghatározását a Matlab programmal végeztem el. A beépített fminsearch nemlineáris minimumkereső programmal minimalizáltam az $O$ célfüggvényt. A program a NelderMead [74] numerikus módszer alapján határozza meg a többdimenziós függvény minimumát (a mi estünkben ez $2 n$ ). Amint az a 17. ábráról is látszik, egy háromelemü Maxwell-modell már igen jól illeszkedik a mért adatokra. A kapott háromelemű Maxwellmodellből számolt tárolási, veszteségi moduluszok és a komplex viszkozitás abszolút értékek rendre folytonos, szaggatott és pontozott vonallal tüntettem fel.

Az illesztett paramétereket az 1. táblázat mutatja. A táblázat a relaxációs időket (relaxation times) is tartalmazza, ez a paraméter nem más, mint az $n$. elemre jutó viszkozitás és elasztikus paraméter hányadosa $\left(\lambda_{i}=\eta_{i} / k_{i}\right)$.

\begin{tabular}{|c|c|c|c|}
\hline Elemszám & $\eta_{i}[\mathrm{Pas}]$ & $k_{i}[\mathrm{~Pa}]$ & $\lambda_{i}[\mathrm{~s}]$ \\
\hline 1 & 124,52 & 671,2 & 0,186 \\
\hline 2 & 273,2 & 13424,6 & 0,02 \\
\hline 3 & 122,8 & 58958,8 & 0,002 \\
\hline
\end{tabular}

1. táblázat: A $60^{\circ} \mathrm{C}$-os SAOS mérésre illesztett háromelemú Maxwell-modell paraméterei

A Maxwell-modell elmélete szerint a viszkozitási paraméterek összege megegyezik a kis nyírási sebességnél (azaz a newtoni tartományban) mért dinamikai viszkozitással. Méréseim szerint $60{ }^{\circ} \mathrm{C}$ hőmérsékleten az AK1.000.000 minta dinamikai viszkozitása 519,5 Pas a newtoni tartományban, az 1. táblázatban szereplő viszkozitási paraméterek összege pedig 520,5 Pas, ami kiváló egyezést mutat.

Egy Maxwell-modellillesztést akkor tekintünk megfelelönek, ha log-log skálán ábrázolva a relaxációs modulust a relaxációs idő függvényében egy szigorúan monoton csökkenő függvényt kapunk. Az illesztett háromelemü Maxwell-modell paramétereinek ilyen típusú ábrázolását mutatja a 18. ábra. Jól látható, hogy az illesztett paraméterek tökéletesen megfelelnek ennek a feltételnek. 


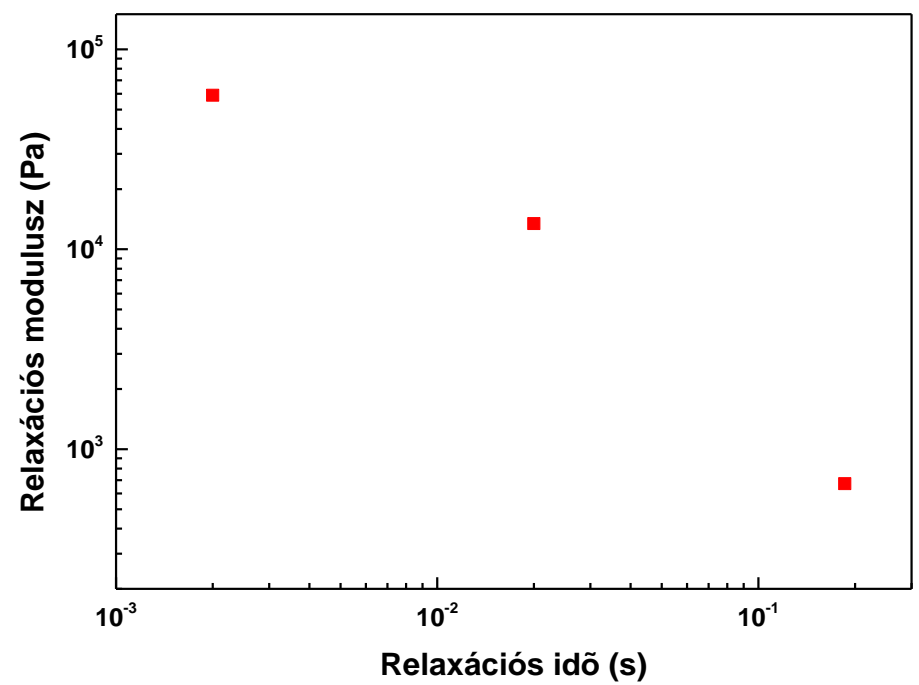

18. ábra: A $60^{\circ} \mathrm{C}$ hőmérsékleti adatokra illesztett háromelemủ Maxwell-modell paraméterei 


\subsection{Rotációs reométerrel mért TTS mestergörbe}

Az MCR101-es reométer (akárcsak a legtöbb kereskedelmi forgalomban kapható reométer) maximum $100 \mathrm{~Hz}$ frekvenciával képes oszcillációs teszteket végezni, ami jelentősen alatta marad a megismerni és modellezni kívánt frekvencia tartománynak. Egyik lehetőség az anyag nagyfrekvenciás vizsgálatára az irodalomjegyzékben bemutatott TTS elv. Ahhoz, hogy ezt a módszert alkalmazhassuk, különböző hőmérsékletü kis amplitúdójú frekvencia-pásztázó méréseket kell végezni, és meg kell vizsgálni, hogy az így mért tárolási és veszteségi moduluszok függőleges és vízszintes eltolásokkal egymással fedésbe hozhatóak-e. Amennyiben igen, akkor az anyag teljesíti a TTS (Time Temperature Superposition) szabályt.

A nyírásvezérelt frekvencia-pásztózó méréseket $\gamma_{0}=5 \%$ nyírási amplitúdóval $\omega=[0.628,628] \mathrm{rad} / \mathrm{s}$ körfrekvencia intervallumban dekádonként 10 pontban, valamint $\mathrm{T}=[0,80]{ }^{\circ} \mathrm{C}$ hőmérséklet tartományban $10{ }^{\circ} \mathrm{C}$-onként végeztük. A méréseket szintén az Anton Paar Physica MCR101-es reométeren a CC10-es fejjel mértük. A különböző frekvencia-pásztázó méréseket ugyanazzal a mintával végeztük. A reométer szoftverén keresztül könnyen beállítható az elérni kívánt hőmérséklet, a pontos hőmérsékletvezérlést egy Peltier elem biztosítja. A müszer leírása szerint a Peltier elem $10^{\circ} \mathrm{C} /$ perc-es hütésifütési karakterisztikával rendelkezik. Az összes mérés elött 15 percet vártam, hogy a minta biztosan elérje a beállított hőmérsékletet, továbbá csináltattunk egy hőszigetelő tetőt is a CC10-es geometriára, hogy a levegővel való érintkezést, és így a minta folyamatos hütését a minimálisra csökkentsük.

A betöltött mintát elöször $0{ }^{\circ} \mathrm{C}$-ra hütöttem, majd $10{ }^{\circ} \mathrm{C}$-onként növeltem a hőmérsékletét. Elérve a maximális $80^{\circ} \mathrm{C}$ hőmérsékletet elkezdtem $10^{\circ} \mathrm{C}$-onként hűteni a mintát egészen a választott minimális $0{ }^{\circ} \mathrm{C}$ hőmérséklet eléréséig. Ha a hütési és a fütési periódusban mért azonos hőmérsékletü mérési eredmények különböztek egymástól, akkor a választott 15 perces várakozási idő vagy nem elegendő az egyes hőmérsékletek pontos elérésére, vagy pedig maga a hőmérsékletváltozás megváltoztatja az anyag belső szerkezetét.

A fütési és hütési periódusban mért azonos hőmérséklet értékhez tartozó eredmények tökéletesen illeszkednek egymásra, így alkalmasak a további vizsgálatokhoz. A 19. ábra a különböző hőmérsékleteken mért tárolási veszteségi moduluszokat mutatja a 
körfrekvencia függvényében. A tárolási moduluszokat folytonos, míg a veszteségi moduluszokat szaggatott vonallal ábrázoltuk.

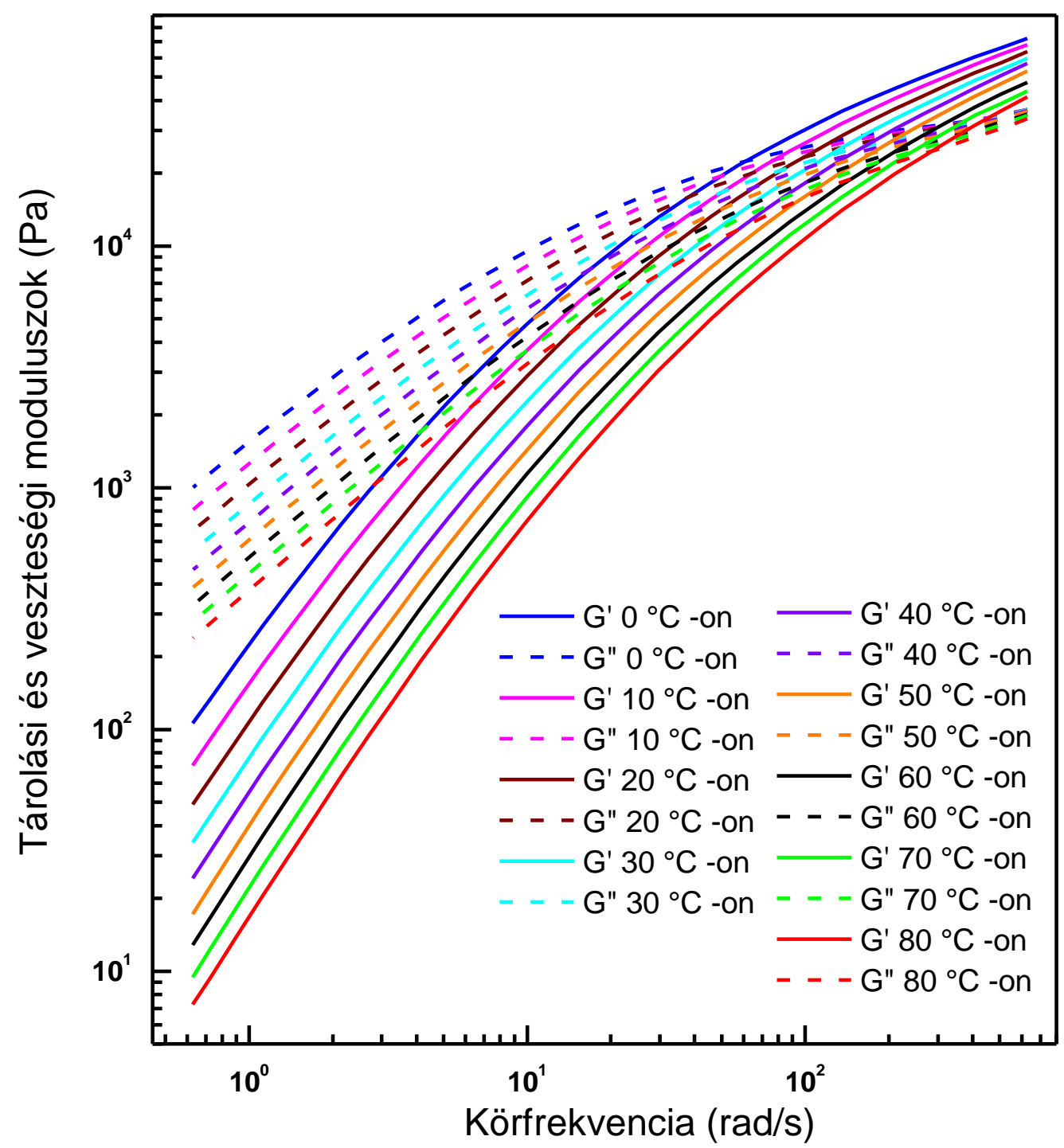

19. ábra: Különböző hőmérsékleten mért tárolási (szaggatott vonalak) és veszteségi (folytonos vonalak) moduluszok a körfrekvencia függvényében.

A különböző hőmérsékleten kapott eredményekből ugyanaz az anyagi viselkedés érvényes a nagy viszkozitású poli-dimetil-sziloxán mintára, mint amit a $60{ }^{\circ} \mathrm{C}$-os frekvenciapásztázó tesztek eredményeinél megállapítottunk:

- A szilikonolaj kis frekvenciák esetén dominánsan viszkózus folyadékként viselkedik $\left(G^{\prime} \gg G^{\prime}\right)$.

- A keresztezési frekvencia felett a szilikonolaj elasztikus jellege erősebb a viszkózus jellegénél $\left(G^{\prime}<G^{\prime}\right)$. 
A keresztezési frekvencia függ a hőmérséklettől, mégpedig minél nagyobb a hőmérséklet, annál nagyobb az értéke.

A frekvencia-pásztázó oszcillációs méréseim azt mutatják, hogy a szilikonolaj a vizsgált hőmérséklet tartományban termoreológiailag egyszerü anyag, azaz teljesíti a TTS (time temperature superposition) szabályt $[14,15]$. A TTS szabály lehetőséget nyújt egy kiválasztott referenciahőmérsékleten a mestergörbe kiszámításához. Én a $60{ }^{\circ} \mathrm{C}$-ot választottam referenciahőmérsékletnek. A 20. ábra szemlélteti a TTS szabály érvényességét a szilikonolajra. A 20. ábrán a redukált tárolási és veszteségi moduluszokat $\left(\frac{G^{\prime}}{b_{T}} ; \frac{G^{\prime \prime}}{b_{T}}\right)$ a redukált körfrekvencia $\left(a_{T} \cdot \omega\right)$ szerint ábrázoltuk a kiválasztott hőmérsékleten $\left(0{ }^{\circ} \mathrm{C}, 60^{\circ} \mathrm{C}\right.$, és $\left.80^{\circ} \mathrm{C}\right)$. A 20 . ábrán jól látszik, hogy a görbék tökéletesen illeszkednek egymásra, így a TTS szabály érvényes az anyagra. A kiválasztott $T_{r e f}=60^{\circ} \mathrm{C}$ referenciahőmérsékleten a mestergörbe kiszámolásával a körfrekvencia tartományt $0,44 \mathrm{rad} / \mathrm{s}-$ tól $2,5 \cdot 10^{3} \mathrm{rad} / \mathrm{s}-$ ig tudtam kiterjeszteni.

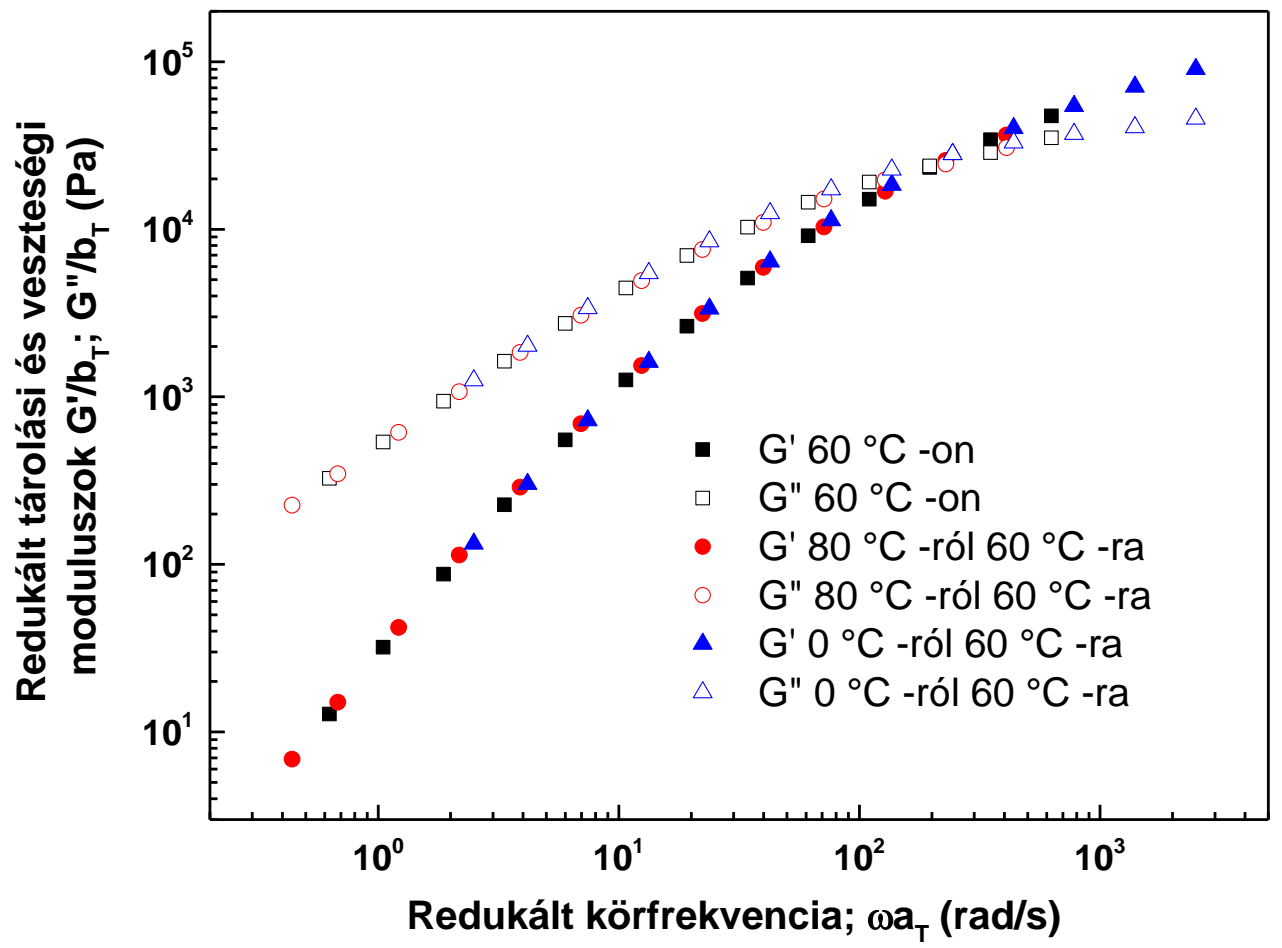

20. ábra Time temperature Superposition (TTS) szabály érvényessége az AK1.000.000 Wacker szilikonolajra. A redukált tárolási (teli szimbólumok) $G^{\prime} / b_{T}$ és veszteségi (üres szimbólumok) $G$ " $/ b_{\mathrm{T}}$ moduluszokat a redukált körfrekvencia $\omega \mathrm{a}_{\mathrm{T}}$ szerint ábrázoltam a kiválasztott hőmérsékleten $\left(0^{\circ} \mathrm{C}, 60^{\circ} \mathrm{C}\right.$, és $\left.80^{\circ} \mathrm{C}\right)$. A különböző hőmérsékleten mért SAOS görbék nagyon jó átfedéssel tolhatók egymásra. 
A $60{ }^{\circ} \mathrm{C}$ hőmérsékletre kiszámolt mestergörbe nagy pontossággal (3\%-nál kisebb hibával) leírható egy ötelemủ Maxwell-modellel, amelynek általam illesztett paramétereit az 2. táblázat tartalmazza az AK1.000.000 minta esetére.

\begin{tabular}{|c|c|c|c|}
\hline Elemszám & $\eta_{i}[\mathrm{Pas}]$ & $k_{i}[\mathrm{~Pa}]$ & $\lambda_{i}[\mathrm{~s}]$ \\
\hline 1 & 43,9 & 76702 & $5,72 \mathrm{E}-4$ \\
\hline 2 & 140,4 & 30290 & 0,00464 \\
\hline 3 & 212,5 & 8138 & 0,0261 \\
\hline 4 & 105,35 & 689,6 & 0,153 \\
\hline 5 & 16,8 & 11,21 & 1,49 \\
\hline
\end{tabular}

2. táblázat: A SAOS mérésekből számolt mestergörbére illesztett ötelemú Maxwell-modell paraméterei, $60^{\circ} \mathrm{C}$-on

A viszkozitási paraméterek összege most is megegyezik a kis nyírási sebességnél (azaz a newtoni tartományban) mért dinamikai viszkozitással. Mérései szerint $60{ }^{\circ} \mathrm{C}$ hőmérsékleten az AK1.000.000 minta dinamikai viszkozitása 519,5 Pas a newtoni tartományban, a 2. táblázatban szereplő viszkozitási paraméterek összege pedig 519 Pas, ami egészen kiváló egyezést mutat.

Az illesztett ötelemű Maxwell-modell relaxációs spektrumát (relaxációs modulusz a relaxációs idő függvényében) a 21. ábrán vázoltam. Jól látható, hogy az illesztett paraméterek szigorúan monoton csökkenő függvénnyel írhatók le, így tökéletesen megfelelnek az elvárt kritériumnak.

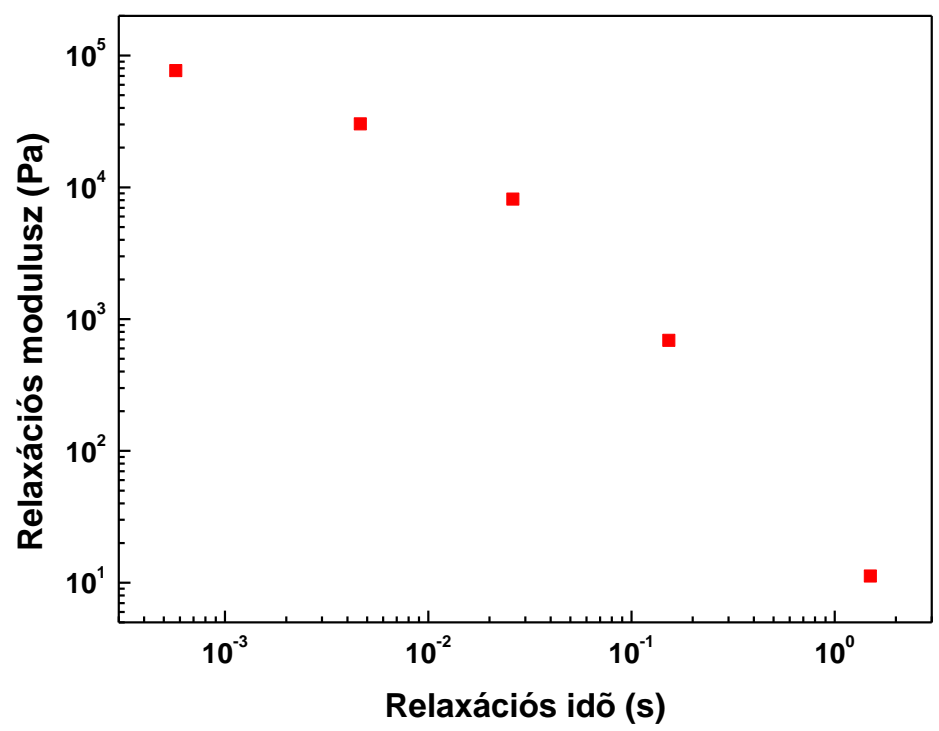

21. ábra: A SAOS mérésekből számolt, $60^{\circ} \mathrm{C}$-ra érvényes mestergörbére illesztett ötelemü Maxwell-modell paraméterei 
A horizontális $a_{T}$ és vertikális $b_{T}$ eltolási faktorok az alábbi szabályok szerint számolhatók ki [75]:

$$
\begin{aligned}
& b_{T} \cdot G^{\prime}\left(a_{T} \omega, T_{r e f}\right)=G^{\prime}(\omega, T) \\
& b_{T} \cdot G^{\prime \prime}\left(a_{T} \omega, T_{r e f}\right)=G^{\prime \prime}(\omega, T),
\end{aligned}
$$

ahol $T$ a mérési hőmérséklet $T_{r e f}$ a referenciahőmérséklet. $G$ ' a tárolási, $G$ ” a veszteségi modulus, $\omega$ pedig a mérési körfrekvencia. Vagyis a horizontális és vertikális eltolási faktorok megmutatják, hogy az adott hömérsékleten és körfrekvencián lévő tárolási és veszteségi moduluszok $\left[G^{\prime}(\omega, T) ; G^{\prime \prime}(\omega, T)\right]$ milyen vertikális és horizontális eltolással kerülnek fedésbe a referenciahőmérsékleten mért tárolási és veszteségi moduluszokkal [ $\left.b_{T} \cdot G^{\prime}\left(a_{T} \omega, T_{r e f}\right), \quad b_{T} \cdot G^{\prime \prime}\left(a_{T} \omega, T_{r e f}\right)\right]$. A vertikális és horizontális eltolási faktorok numerikus optimalizációval megkaphatók. Keressük azokat az $a_{T}, b_{T}$ paramétereket, amelyre a referenciahőmérsékleten mért görbére a lehető legjobban illeszkednek az eltolt ún. redukált tárolási és veszteségi moduluszok. A reométer szoftver alkalmas a kiválasztott referenciahőmérsékleten a mért adatok alapján a vertikális és horizontális eltolási faktorok kiszámításra.

A kis amplitúdójú rotációs reométeres mérésekből számolt vertikális és horizontális eltolási faktorokat a 3. táblázat tartalmazza $60{ }^{\circ} \mathrm{C}$-os referenciahőmérséklet esetén.

\begin{tabular}{|c|c|c|}
\hline Hömérséklet & $\begin{array}{c}\text { Horizontális eltolási } \\
\text { faktor }\end{array}$ & $\begin{array}{c}\text { Vertikális eltolási } \\
\text { faktor }\end{array}$ \\
\hline $\mathrm{T}\left[{ }^{\circ} \mathrm{C}\right]$ & $a_{T}$ & $b_{T}$ \\
\hline 0 & 3,7368 & 0,87151 \\
\hline 10 & 2,8752 & 0,89478 \\
\hline 20 & 2,2602 & 0,91563 \\
\hline 30 & 1,8066 & 0,93721 \\
\hline 40 & 1,4671 & 0,9577 \\
\hline 50 & 1,2045 & 0,97878 \\
\hline 60 & 1 & 1 \\
\hline 70 & 0,8364 & 1,0227 \\
\hline 80 & 0,70634 & 1,044 \\
\hline
\end{tabular}

3. táblázat: Rotációs reométeres mérések eredményeből számolt vertikális és horizontális TTS eltolási faktorok a hőmérséklet függvényében, az alkalmazott $\quad 60{ }^{\circ} \mathrm{C}$-os referenciahőmérsékleten

A 22. ábra a hőmérséklet függvényében mutatja a SAOS mérések összetolásából számított TTS eltolási faktorokat. A piros négyzetek a vertikális, míg a fekete körök a horizontális eltolási faktorokat jelölik. Mind a horizontális, mind a vertikális eltolási 
paramétereknek léteznek analitikus meghatározásai. A horizontális paraméterek illesztésére leggyakrabban az Arrhenius [75] vagy a Williams-Landel-Ferry (WLF) [15] formulát alkalmazzák. Mint ahogyan azt az ábrán a piros görbe mutatja, a horizontális eltolási faktorok nagyon pontosan illeszthetők az Arrhenius egyenlettel (piros görbe):

$$
a_{T}=a(T)=\exp \left(\frac{E_{A}}{R} \cdot\left(\frac{1}{T}-\frac{1}{T_{r e f}}\right)\right),
$$

ahol $E_{A}$ az aktivációs energia, $R$ az egyetemes gázállandó. Az illesztés során az aktiválási energia 16,58 kJ/mol-nak adódott, ami jól egyezik az irodalomban található értékekkel [64, 67].

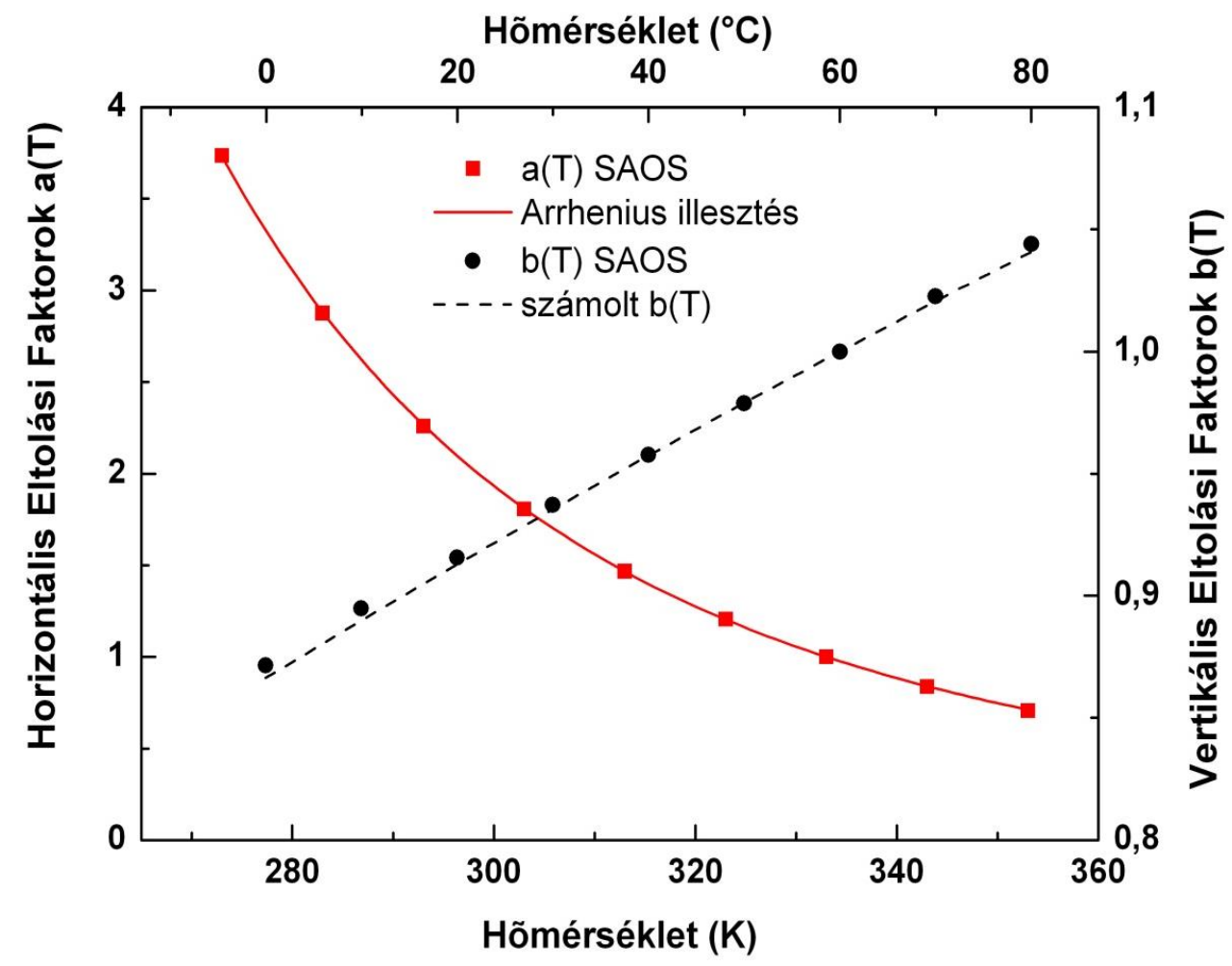

22. ábra: Az $a_{T}$ horizontális (piros négyzet) és a $b_{T}$ horizontális (fekete kör) TTS eltolási faktorok a hőmérséklet függvényében (a referenciahőmérséklet $60^{\circ} \mathrm{C}$ ). A piros vonal az Arrhenius formula (5.4 egyenlet) alapján számított horizontális eltolási faktor görbéje, amely tökéletesen illeszkedik a SAOS mérésekből származtatott $a_{T}$ értékekre. A szaggatott vonal a 5.5 egyenlet alapján számolt vertikális eltolási faktor görbéje, amely szintén kiválóan illeszkedik a SAOS mérésekből származtatott bT értékekre.

A vertikális eltolási faktorok elemzéséhez az alábbi elméleti képletet használtam [14]:

$$
b_{T}=b(T)=\frac{\rho(T) \cdot T}{\rho\left(T_{r e f}\right) \cdot T_{r e f}},
$$


ahol $\rho(T)$ az adott, míg $\rho\left(T_{\text {ref }}\right)$ a referenciahőmérsékleten mért sürüség. A mért hőmérséklet tartományban $\left(0{ }^{\circ} \mathrm{C}\right.$-tól $80^{\circ} \mathrm{C}$-ig) a szilikonolaj sürüsége az alábbi formulával számolható [76]:

$$
\rho(T)=\rho\left(T_{0}\right) /\left(1+A \cdot\left(T-T_{0}\right)+B \cdot\left(T-T_{0}\right)^{2}\right),
$$

ahol $T_{0}=25{ }^{\circ} \mathrm{C}, \quad \rho\left(T_{0}\right)=0.97 \mathrm{~g} / \mathrm{cm}^{3}, A=9.2 \cdot 10^{-4}{ }^{\circ} \mathrm{C}^{-1} ; B=4.5 \cdot 10^{-7}{ }^{\circ} \mathrm{C}^{-2}$. A 20. ábra mutatja, hogy a mért (teli fekete pontok) és a fenti képletek alapján számolt (szaggatott fekete vonal) vertikális eltolási faktorok kiválóan illeszkednek egymásra.

A TTS szabály azt is lehetővé teszi számunkra, hogy a mestergörbéhez illesztett Maxwell-modell $k_{i}$ és $\eta_{i}$ paramétereiből egy más hőmérsékleten érvényes Maxwell-modell $k_{i}(T)$ és $\eta_{i}(T)$ paramétereit kiszámítsuk az alábbi képletek segítségével [15]:

$$
\begin{aligned}
& k_{i}(T)=b(T) \cdot k_{i}, \\
& \eta_{i}(T)=b(T) \cdot a(T) \cdot \eta_{i} .
\end{aligned}
$$

A hőmérsékletfüggő paramétereket tartalmazó lineáris Maxwell-modellt egy „virtuális reométer” segítségével teszteltem. Ez egy általam kifejlesztett MATLAB program, amelynek segítségével egy valódi reométer által elérhető tesztek (állandó sebességü nyírás, oszcillációs teszt, stb.) eredményét lehet kiszámítani. A virtuális reométerben tipikusan nyírási sebességet írunk elő az idő függvényében, majd a szimuláció során a vizsgált anyagra jellemző konstitúciós egyenlet felhasználásával meghatározzuk, hogy mi lenne a valódi reométer által mért nyírófeszültség. Ebböl, a definíciók szerint, kiszámítjuk a releváns reometriai mennyiségeket, mint pl. a tárolási és veszteségi modulusokat, vagy a komplex viszkozitás abszolút értékét, amelyeket ezután összevethetünk a valódi reométer által mért értékekkel.

A 23. ábrán a $60^{\circ} \mathrm{C}$ hőmérsékleten érvényes mestergörbéket vetettem össze a virtuális reométer által szimulált SAOS tesztből származó tárolási és veszteségi modulusz értékekkel. A szimuláció során a Maxwell-modell paraméterei a 2. táblázatban szereplő értékekre voltak beállítva. A mért és a számított adatok igen jól illeszkednek egymáshoz. 


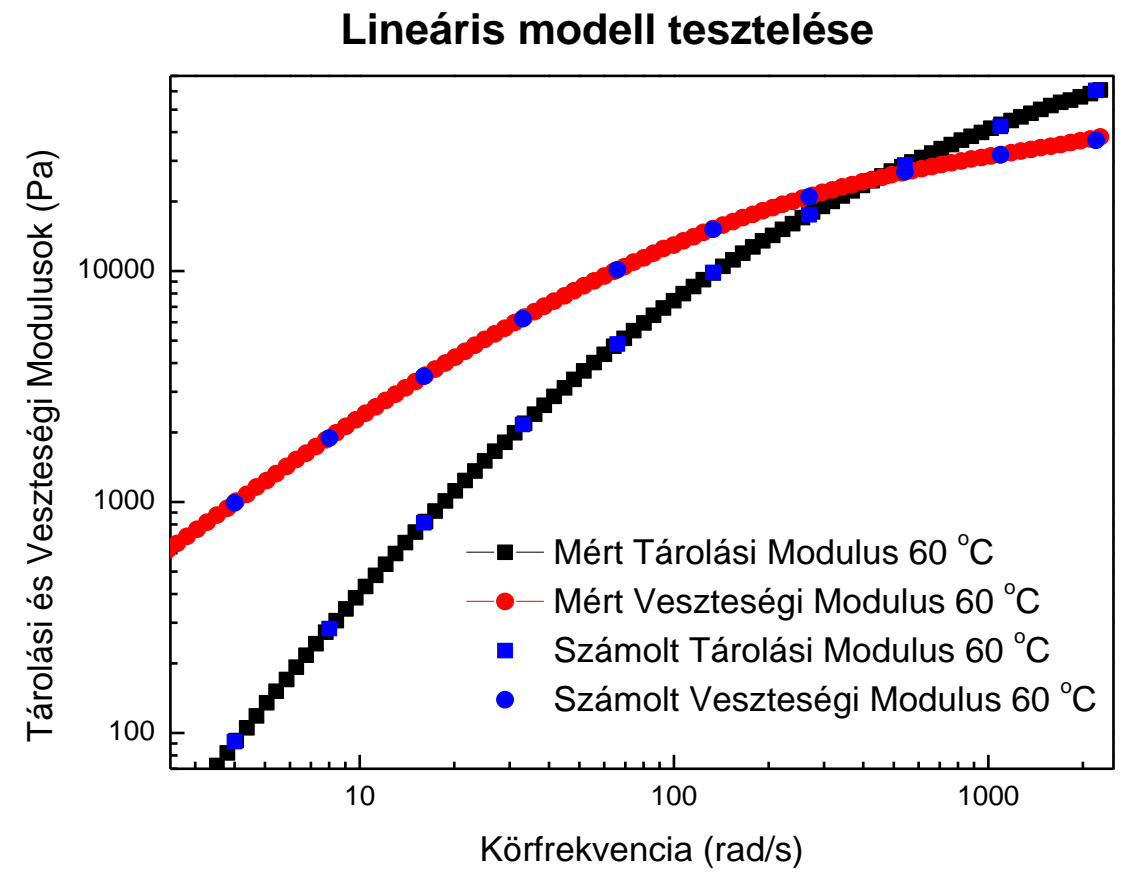

23. ábra: Az ötelemű Maxwell-modell pontossági tesztje $60^{\circ} \mathrm{C}$ hőmérsékleten. A piros és fekete görbék a reométeres mérésekből a TTS szabály alkalmazásával kapott mestergörbék. Az ezekhez illesztett ötelemü Maxwell-modell alapján számítógépes szimulációval kiszámított értékeket a kék szimbólumok jelzik.

A 24. ábra az ötelemü Maxwell-modell pontosságát mutatja $20^{\circ} \mathrm{C}$, illetve $80^{\circ} \mathrm{C}$ hőmérsékleteken. A „virtuális reométer” először átszámítja a viszkózus és elasztikus paramétereket a beállított hőmérsékletre az (5.6) és (5.7) formulák szerint, majd ezek segítségével végrehajtja a szimulációs tesztet. A számított értékeket a mért értékekkel összevetve továbbra is jó egyezést kapunk.
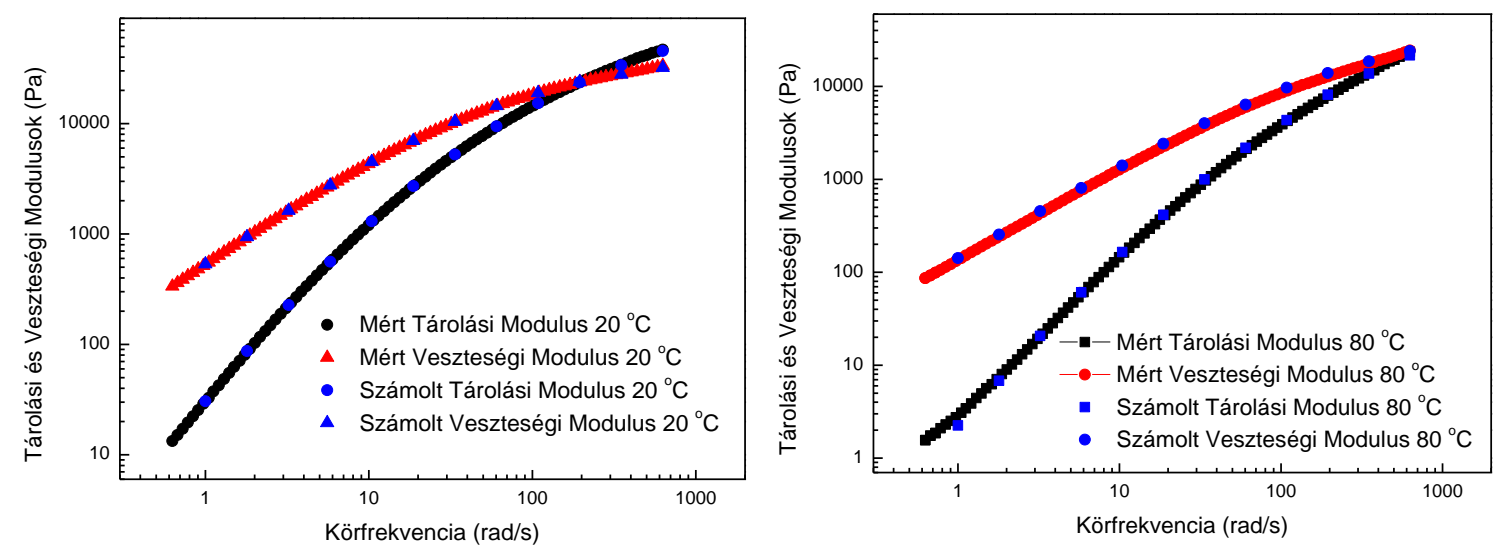

24. ábra: Az ötelemü Maxwell-modell pontossága 20 és $80^{\circ} \mathrm{C}$ hőmérsékleteken. A piros és fekete görbék a reométeres mérésekből kapott tárolási és veszteség moduluszok. Az ezekhez illesztett ötelemü Maxwell-modell alapján számítógépes szimulációval kiszámított értékeket a kék szimbólumok jelzik. 


\subsection{Cox-Merz szabály érvényessége a rotációs reométerrel mért adatokra}

Összevetve a rotációs reométerrel mért nyírási, illetve oszcillációs teszteket azt tapasztaltuk, hogy a szilikonolaj teljesíti a Cox-Merz szabályt (2.16 egyenlet). Azaz, ha a dinamikai viszkozitást a nyírási sebesség függvényében, valamint a komplex viszkozitás abszolút értékét a körfrekvencia függvényében egyazon grafikonon ábrázoljuk, akkor a görbék igen pontosan illeszkednek egymásra. A szilikonolaj esetében a szabály teljesülése jól látszik a 25. ábrán (a piros kör az oszcillációs mérések során kapott komplex viszkozitás abszolút értékét, míg a kék háromszög a nyírási tesztek során mért dinamikai viszkozitást jelöli). A Cox-Merz szabály egy tapasztalati összefüggés, amely általában a Maxwell-típusú viszkoelasztikus folyadékokra érvényes [75], vagyis tipikusan telítetlen polimer oldatokra és polimer olvadékokra, amikor elsősorban a molekulák közötti mechanikai jellegü kölcsönhatások felelősek a reológiai jellemzőkért. Ebből következően a Cox-Merz szabályt csak abban a tartományban tekinthetjük igaznak, amelyben méréssel is ellenőrizni tudjuk. A fentiek alapján pedig a rotációs reométerrel erre csak 20 1/s nyírási sebességig van lehetőségünk.

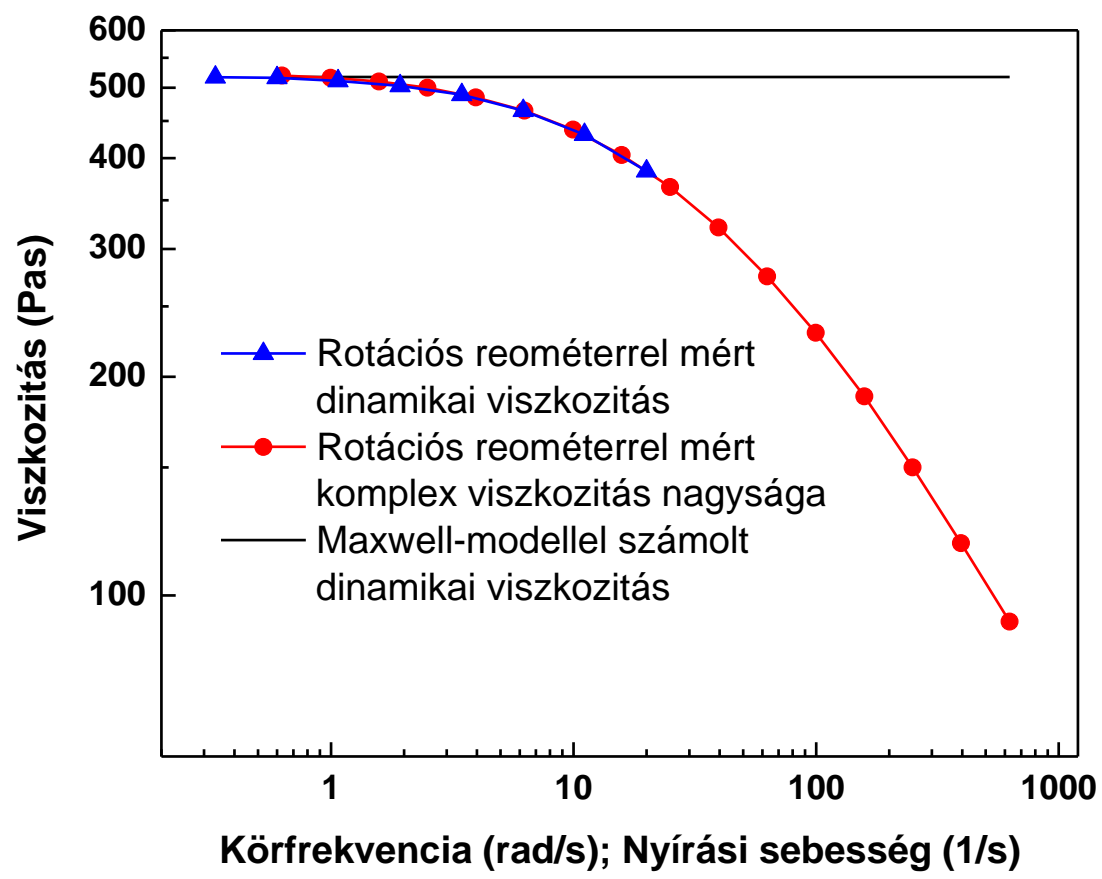

25. ábra: A Cox-Merz szabály szemléltetése. Az AK1.000.000 minta $60{ }^{\circ} \mathrm{C}$ hőmérsékleten mért dinamikai viszkozitásának (kék háromszög) a nyírási sebességtől való függése megegyezik a komplex viszkozitás abszolút értékének (piros kör) a körfrekvenciától való függésével. A lineáris modell (fekete vonal) által jósolt dinamikai viszkozitás (azaz a newtoni tartományban érvényes dinamikai viszkozitás) nem függ a nyírási sebességtől. 
Mint ahogyan az a 25. ábrán is jól látszik, a lineáris modell (fekete vízszintes vonal) nem képes a szilikonolaj nyírási sebességtől függő dinamikai viszkozitását leírni. Ahhoz, hogy ezt szimulálni tudjuk a szilikonolaj reológiai modelljének továbbfejlesztése szükséges. A legegyszerübb nemlineáris viszkoelasztikus modell az irodalmi áttekintésben bemutatott White-Metzner-modell [18], amely a Maxwell-modell egyszerü továbbfejlesztése: Feltesszük, hogy a csillapító elem viszkozitása függ a nyírási sebességtől. Így a konstitúciós egyenlet a 2.17 egyenletnek megfelelően alakul. A CoxMerz szabály figyelembevételével könnyen megkapható a szilikonolaj dinamikai viszkozitása a nyírási sebesség függvényeként: ez ugyanis megegyezik a komplex viszkozitás abszolút értékének körfrekvencia függésével, a körfrekvenciát egyszerủen kicseréljük a nyírási sebességre a 2.16 formula szerint. Ez az egyelemű White-Metznermodell azonban nyilván nem elég pontos, hiszen a TTS szabály alapján kapott mestergörbét egy ötelemü Maxwell-modell illeszti pontosan.

Ha egy többelemü Maxwell-modellt szeretnénk úgy átalakítani, hogy dinamikai viszkozitása is függjön a nyírási sebességtől, akkor azt is el kell döntenünk, hogy az egyes elemek között hogyan „osszuk szét” a viszkozitási paraméter eredő értékét. Első lépésben az alábbi egyszerü módszert választottam:

$$
\eta_{i}(\dot{\gamma})=\frac{\eta_{i}}{\sum_{j} \eta_{j}} \cdot\left|\eta^{*}(\omega)\right|_{\dot{\gamma}=\omega}
$$

Vagyis az egyes elemekre jutó nyírási sebesség függő viszkózus paraméterek $\eta_{i}(\dot{\gamma})$ a CoxMerz szabály alapján számolt komplex viszkozitás abszolút értékének $\left|\eta^{*}(\omega)\right|_{\dot{\gamma}=\omega}$ a kezdeti viszkozitások arányában elosztott hányadaként számolhatók. Az így készült ötelemü állandó súlyozású White-Metzner-modell pontosan leírja a dinamikai viszkozitás nyírási sebesség függését, másrészt kis amplitúdójú oszcillációs tesztek esetén úgy viselkedik, mint az ötelemü Maxwell-modell. Az így készült állandó súlyozású White-Metzner-modell azonban csak nagyon pontatlnaul képes az amplitúdó-pásztázó tesztek során mért csökkenő tárolási és veszteségi moduluszok megadására. Ehhez egy továbbfejlesztett, ún. változó súlyozású White-Metzner-modell bizonyult alkalmasnak, amelyet az 5.8 alfejezetben mutatok be részletesen. 


\subsection{Nagyfrekvenciás reometria a DWS módszer segítségével}

Ahhoz, hogy magasabb frekvencia tartományokban $\left(\omega>2,5 \cdot 10^{3} \mathrm{rad} / \mathrm{s}\right)$ is képesek legyünk a szilikonolaj reológiai jellemzésére, az irodalmi áttekintésben ismertetett DWS (Diffusing Wave Spectroscopy) eljárást alkalmaztuk, amely a mintán szóródó fény fluktuációjából tud a minta lineáris viszkoelasztikus jellemzőire következtetni. A szilikonolaj egy átlátszó anyag, így a fény szóródását mesterségesen kellett előidézni, nyomjelző részecskéket kellett eloszlatni a mintában. A nagy viszkozitású PDMS fényszórásos vizsgálatához titán-dioxid nyomjelző részecskék bizonyultak a legmegfelelőbbnek. A titán-dioxid nyomjelző részecskék szilikonolajban történő egyenletes elkeverése egy bonyolult folyamat. Ennek részletes leírását a 4.3 alfejezet tartalmazza. Az egyenletesen eloszlatott, jól definiált átlagos hidrodinamikai átmérővel $(200 \pm 80$ nm) rendelkező nyomjelző részecskéket tartalmazó mintán már elvégezhettük a DWS méréseket. A nagy viszkozitású szilikonolajat DWS ReserchLab (LS Instruments) készülékkel vizsgáltuk transzmissziós módban. A készülék tartalmaz egy szoftvercsomagot, amelynek segítségével elvégezhetők a szükséges mikroreológiai számításokat.

A DWS méréseket 20 és $70^{\circ} \mathrm{C}$ között $10^{\circ} \mathrm{C}$-ként végeztük. A szilikonolaj erősen elasztikus jellege korlátozza a frekvencia tartományt, amelyen belül a tárolási és veszteségi modulusok pontosan mérhetőek. A mérések azt mutatták, hogy 10 és $10^{5} \mathrm{rad} / \mathrm{s}$ körfrekvencia értékek között kapunk pontos eredményt. A DWS mérések azt mutatják, hogy a szilikon olaj a vizsgált nagyfrekvenciás tartományban is - a domináns moduluszokra vonatkozóan - jó közelítéssel teljesíti a TTS szabályt, azaz a nagy viszkozitású szilikonolaj a teljes vizsgált frekvencia tartományban termoreológiailag egyszerü anyagnak tekinthető. A 26. ábra a mért eredményeket mutatja. A könnyebb átláthatóság kedvéért a tárolási és veszteségi moduluszok TTS eltolt értékeit mutatja a grafikon. Referenciahőmérsékletnek ismét a $60{ }^{\circ} \mathrm{C}$-ot választottam. A redukált tárolási moduluszokat szaggatott, míg a veszteségi moduluszokat folytonos vonalakkal ábrázoltam. A keresztezési frekvencia felett az összes vizsgált hőmérsékleten a tárolási modulusz válik meghatározóvá ( $\left.G^{\prime}>>G^{\prime}\right)$. A vizsgált nagyfrekvenciás tartományban a tárolási modulusz frekvenciafüggése megmarad, míg a veszteségi modulusz gyakorlatilag frekvencia függetlenné válik. Ha közelebbről megvizsgáljuk a nyers DWS korrelációs adatokat, akkor 
az is megállapítható, hogy nincs második keresztezési pont $10^{8} \mathrm{rad} / \mathrm{s}$ körfrekvenciáig (maximálisan mérhető körfrekvencia).

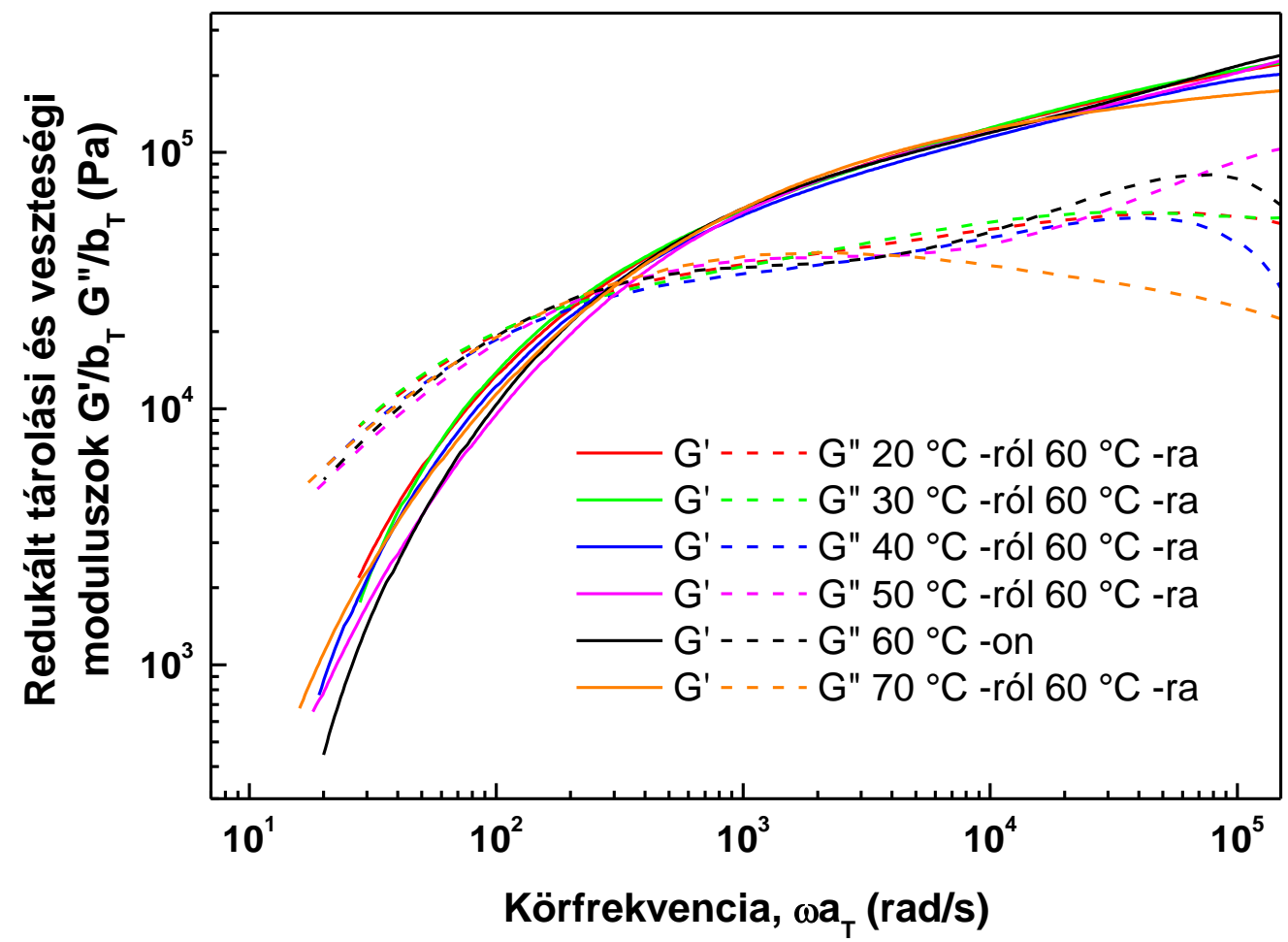

26. ábra: AK1.000.000 szilikonolaj DWS módszerrel mért eredményeiből számított redukált tárolási (folytonos vonalak) és veszteségi (folytonos vonalak) moduluszok a redukált körfrekvencia függvényében. A színek a különböző alaphőmérsékleteket jelölik (a referenciahőmérséklet $60^{\circ} \mathrm{C}$ ). A DWS mérések TTS eltoláshoz alkalmazott horizontális és vertikális eltolási faktorokat a 22 . ábra mutatja.

Itt meg kell jegyeznünk, hogy ilyen nagy viszkoelasztikus modulusszal rendelkező minták DWS módszerrel történő mérési eredményeinek kiértékelése nem triviális. A szilikonolaj lassú dinamikája (nagy viszkozitása) akadályozza a nyomjelző részecskék megfelelő eloszlatását, még az alkalmazott társoldószer használata mellett is. A nyomjelző részecskék nagy koncentrációja azért szükséges, hogy a DWS jelet szignifikánsan el tudjuk különíteni a vizsgálni kívánt idö/frekvencia intervallumban. A DWS technika azonban csak akkor alkalmazható, ha a nyomjelző részecskék nincsenek kölcsönhatásban egymással (mintha híg oldatot állítanánk elő). A 2.5 wt\%-os részecskekoncentráció épp a követelmény határán van: amennyiben növeljük a koncentrációt, úgy a részecske-részecske kölcsönhatás elkezd megjelenni a szóródási jelben, így a mérés nem ad értelmezhető eredményt. Amennyiben csökkentjük a koncentrációt, akkor pedig a szórt jel intenzitása fog jelentősen csökkeni. A $100 \mathrm{rad} / \mathrm{s}$ alatti körfrekvenciák esetén a DWS jelet erősen befolyásolja az ECHO technika [77]. A méréshez használt DWS ReserchLab (LS 
Instruments) készülék a $10 \mathrm{rad} / \mathrm{s}$ körfrekvencia érték alatt nem ad statisztikailag értelmezhető adatot.

A DWS mérésekből számolt vertikális és horizontális eltolási faktorokat a 4. táblázat tartalmazza, $60{ }^{\circ} \mathrm{C}$-os referenciahőmérséklet esetén.

\begin{tabular}{|c|c|c|}
\hline Hőmérséklet & $\begin{array}{c}\text { Horizontális } \\
\text { eltolási faktor }\end{array}$ & $\begin{array}{c}\text { Vertikális eltolási } \\
\text { faktor }\end{array}$ \\
\hline $\mathrm{T}\left[{ }^{\circ} \mathrm{C}\right]$ & $\mathrm{a}_{\mathrm{T}}$ & $\mathrm{b}_{\mathrm{T}}$ \\
\hline 20 & 2,82 & 0,72 \\
\hline 30 & 2,3 & 0,82 \\
\hline 40 & 1,35 & 0,83 \\
\hline 50 & 1,04 & 0,97 \\
\hline 60 & 1 & 1 \\
\hline 70 & 0,8 & 1,03 \\
\hline
\end{tabular}

4. táblázat: DWS mérések eredményeből számolt vertikális és horizontális TTS eltolási faktorok a hőmérséklet függvényében, az alkalmazott $60^{\circ} \mathrm{C}$-os referenciahőmérsékleten

A 27. ábra tartalmazza a SAOS (3. táblázat) és DWS (4. táblázat) mérési eredmények alapján kiszámított TTS eltolási paramétereket ( $a_{T}$ és $b_{T}$ ). Alacsonyabb hőmérsékleteken a két mérési típusra (SAOS, DWS) vonatkozó vertikális és horizontális eltolási faktorok különböznek egymástól. Ez az eltérés a fent említett mérési nehézségek következménye. Valójában a szilikonolaj dinamikája annyira alacsonnyá válik kis hőmérsékleteken $\left(20-30^{\circ} \mathrm{C}\right)$, hogy a mért DWS dekorrelációs jel alig különbözik az 1-es értéktől (szóródás nélküli jel) a mérhető korrelációs időkben. Ez erősen csökkenti a viszkoelasztikus modulusok (tárolási és veszteségi) és a keresztezési körfrekvencia pontosságát, valamint kisebb mértékben, de a görbék alakját is befolyásolja. A veszteségi moduluszok 26. ábrán látható $10^{4} \mathrm{rad} / \mathrm{s}$ körfrekvencia feletti egymástól való eltérése is ezzel a megfontolással magyarázható. 


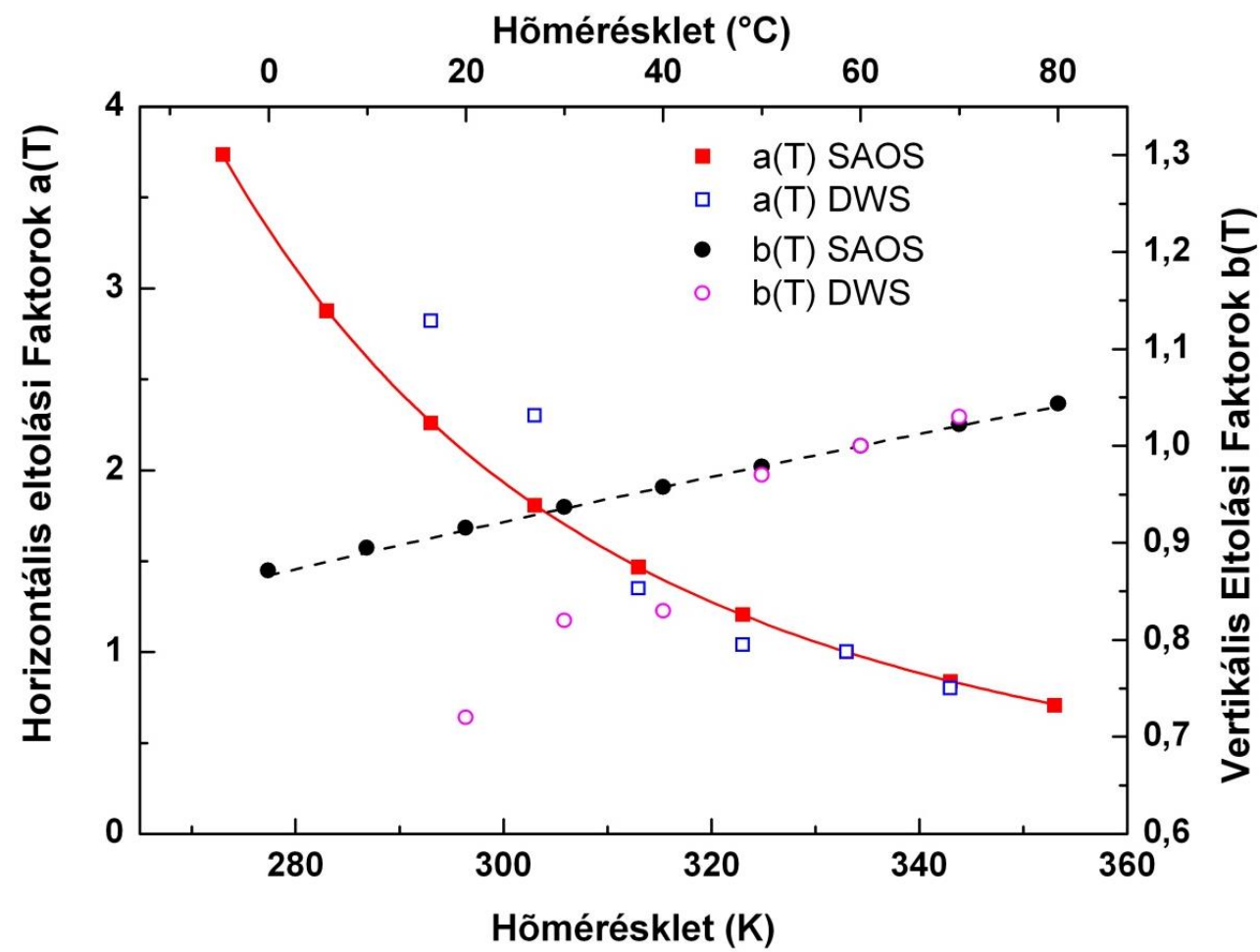

27. ábra: Az aT horizontális és bT a vertikális TTS eltolási faktorok a hőmérséklet függvényében, a referenciahőmérséklet $60{ }^{\circ} \mathrm{C}$. A teli szimbólumok a rotációs reométer, az üres szimbólumok a DWS adataiból (3. és 4. táblázat) származtatott eltolási faktorokat jelölik.

A fenti említett problémák ellenére a két módszer (SAOS, DWS) egyezése igen jónak tekinthető. Még a DWS technikánál szokásos skálázási együtthatókra sincs szükség az egyezés eléréséhez. A 28 . ábra mutatja be négy különböző hömérsékleten $\left(20^{\circ} \mathrm{C}, 30^{\circ} \mathrm{C}\right.$, $60^{\circ} \mathrm{C}$, és $70^{\circ} \mathrm{C}$ ) a két módszerrel kapott mérési eredményeket. A domináns (tárolási) moduluszok nagyon jól illeszkednek egymásra az átfedésben lévő frekvencia tartományon, különösképpen a magasabb hömérsékleten. A DWS és SAOS adatok eltérését a $100 \mathrm{rad} / \mathrm{s}$ alatti körfrekvenciáknál a DWS mérési beállítás kicsiny elhangolása okozhatja. 

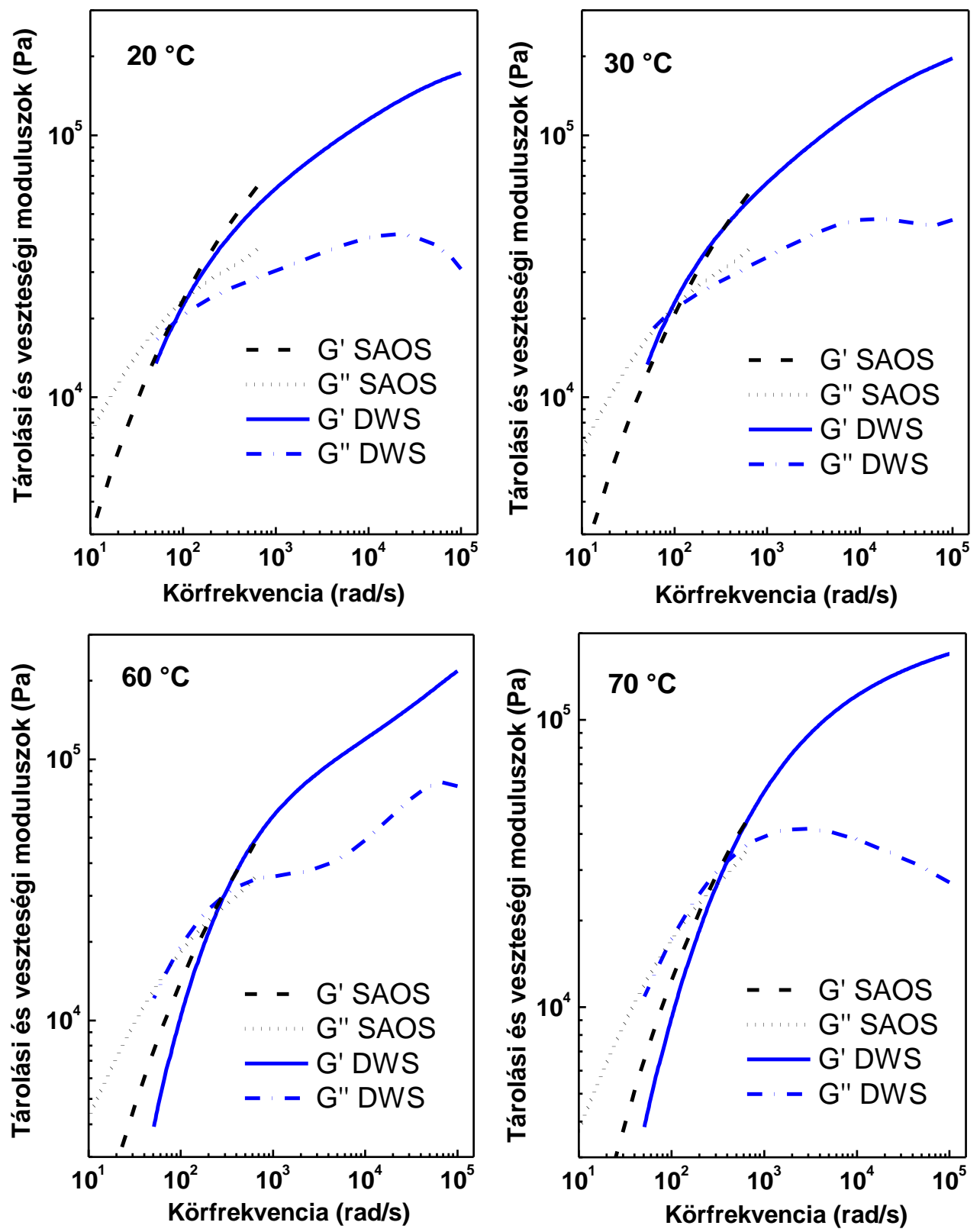

28. ábra: SAOS és DWS módszerrel mért tárolási és veszteségi moduluszok összehasonlítása $20^{\circ} \mathrm{C}$, $30{ }^{\circ} \mathrm{C}, 60^{\circ} \mathrm{C}$ és $70^{\circ} \mathrm{C}-$ on. 


\subsection{Lineáris viszkoelasztikus modell}

A $60^{\circ} \mathrm{C}$-on mért SAOS és DWS adatok kiválóan illeszkednek egymásra, így kézenfekvő, hogy egyetlen, a két adatsor összefüzéséből kapott mestergörbét határozzunk meg erre a hőmérsékletre. A mestergörbe meghatározásához mind a SAOS mind DWS adatokat a $60^{\circ} \mathrm{C}$-os referenciahőmérsékletre toltuk (19. és 26. ábrák). Mivel a tárolási moduluszok nagyon jól illeszkednek egymásra a nagyfrekvenciás tartományban (26. ábra), ott egyszerüen a $60^{\circ} \mathrm{C}$-os DWS mérés adatait vettük bele a mestergörbébe. A veszteségi moduluszok nagyfrekvenciás pontatlanságát az egyes hőmérsékleten mért veszteségi moduluszok $60^{\circ} \mathrm{C}$-ra tolt (TTS módszert alkalmazva, a 3. táblázatban feltüntetett eltolási paraméterekkel) átlagával küszöböltük ki. Az így kapott tárolási és veszteségi moduluszokat már mintegy hat nagyságrendet átölelő körfrekvencia tartományban $(0,5$ $10^{5} \mathrm{rad} / \mathrm{s}$ ) tudjuk megadni.

$\mathrm{Az}$ egyesített mérési adatokra egy lineáris viszkoelasztikus anyagmodellt illesztettünk. Egy hatelemü Maxwell-modell nagy pontossággal leírja a lineáris viselkedést a teljes frekvencia tartományban. Az illesztett paramétereket az 5. táblázat mutatja.

\begin{tabular}{|c|c|c|c|}
\hline Elemszám & $\eta_{i}[\mathrm{Pas}]$ & $k_{i}[\mathrm{~Pa}]$ & $\lambda_{i}[\mathrm{~s}]$ \\
\hline 1 & 2,17 & 152629,5 & $1,422 \mathrm{E}-5$ \\
\hline 2 & 6,82 & 50230,3 & $1,36 \mathrm{E}-4$ \\
\hline 3 & 191,29 & 22145,2 & 0,00864 \\
\hline 4 & 203,24 & 3901,2 & 0,0521 \\
\hline 5 & 66,99 & 53314,5 & 0,00126 \\
\hline 6 & 54,89 & 149,6 & 0,367 \\
\hline
\end{tabular}

5. táblázat: A SAOS és DWS mérésekből számolt mestergörbére illesztett hatelemủ Maxwell-modell paraméterei, $60^{\circ} \mathrm{C}$-on

A viszkozitási paraméterek összege jelen esetben is megegyezik a kis nyírási sebességnél (azaz a newtoni tartományban) mért dinamikai viszkozitással. Méréseink szerint $60{ }^{\circ} \mathrm{C}$ hőmérsékleten az AK1.000.000 minta dinamikai viszkozitása 519,5 Pas a newtoni tartományban, az 5. táblázatban szereplő viszkozitási paraméterek összege pedig 525,4 Pas, azaz a két adat szintén kiválóan egyezik. 
A 29. ábra mutatja az egyesített mérési adatokra illesztett hatelemü Maxwell-modell relaxációs spektrumát. Jól látható, hogy az illesztett paraméterek szigorúan monoton csökkenő függvénnyel írhatóak le, így tökéletesen megfelelnek az elvárt kritériumnak.

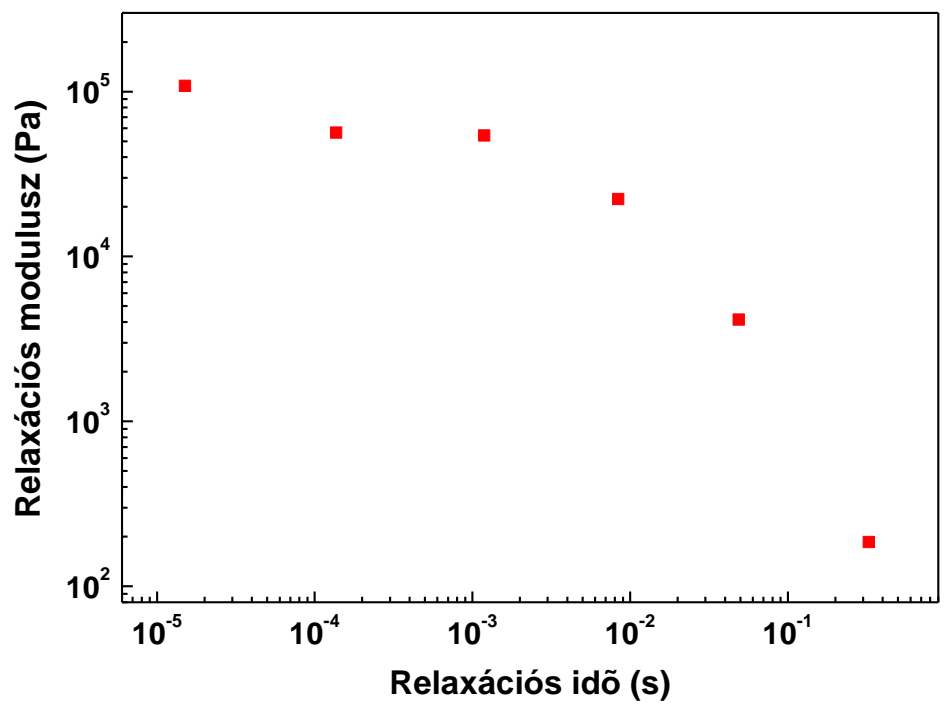

29. ábra: A mért SAOS és DWS adatok alapján számolt mestergörbére illesztett hatelemű Maxwellmodell relaxációs spektruma.

A 30. ábrán az egyesített tárolási és veszteségi modulusz adatok, illetve a rájuk illesztett hatelemü Maxwell-modell látható. A kapott mestergörbe tárolási és veszteségi moduluszait pontokkal, míg az illesztett hatelemű Maxwell-modellt vonalakkal ábrázoltuk. Az illesztés pontosságát jól mutatja, hogy a mért és számított adatok relatív eltérése az egész körfrekvencia tartományban 6\%-nál kevesebb.

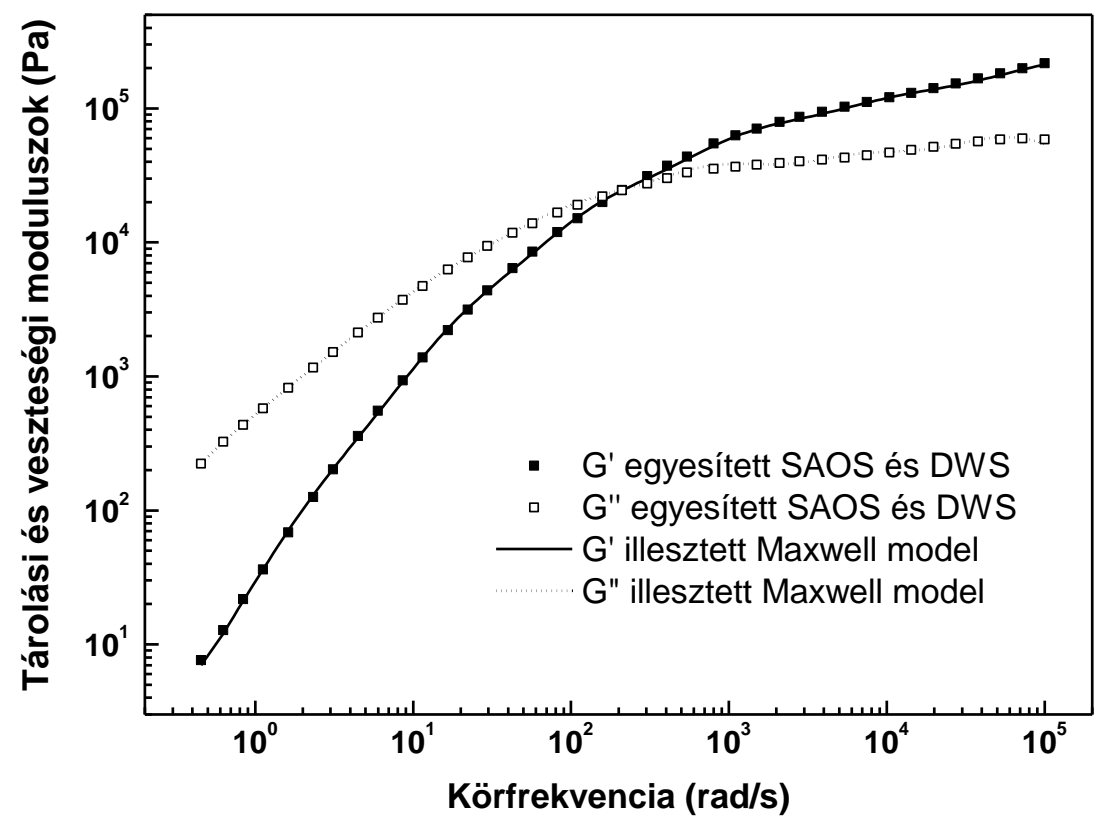

30. ábra: A szilikonolaj egyesített (SAOS és DWS módszer) tárolási és veszteségi moduluszai (pontok) a körfrekvencia függvényében, valamint a rájuk illesztett hatelemű Maxwellmodell (vonalak) látható. A hatelemű modell relaxációs spektruma a 29. ábrán látható. 


\subsection{Nemlinearitás: Pszeudoplasztikus viselkedés és a Cox-Merz szabály}

A rotációs reométerrel mért nyírási tesztek (flow curve) azt mutatják, hogy a szilikonolaj pszeudoplasztikus (shear thinnig) folyadék (15. ábra). A rotációs reométerrel végezhető nyírási teszteknek azonban kb. 20 1/s nyírási sebességnél határt szab az úgynevezett Weissenberg hatás. Összevetve a reométerrel mért nyírási, illetve oszcillációs teszteket azt tapasztaltuk, hogy a nagy viszkozitású szilikonolaj teljesíti a Cox-Merz szabályt a 20 1/s nyírási sebesség értékig (25. és 31. ábrák).

Kapilláris viszkoziméter alkalmazásával lehetőségünk van a viszkozitás mérésére lényegesen nagyobb nyírási sebességeknél is. Méréseinket egy Götfert Rheograph 25 típusú müszerrel végeztük a 100 1/s - 76000 1/s nyírási sebesség tartományban. Az így kapott dinamikai viszkozitás adatokat (lila lefelé néző háromszög) a 31. ábrán mutatom be. Az ábra a könnyebb összehasonlíthatóság érdekében a rotációs reométerrel végzett nyírási (felfelé néző kék háromszög) és oszcillációs tesztek (piros kör) eredményeit is tartalmazza. Abban a nyírási sebesség tartományban, ahol a kapilláris mérés során kapott adatok átfednek a reométeres oszcillációs tesztekből származó komplex viszkozitás abszolút értékekkel, a Cox-Merz szabály teljesülését kérdésesnek is gondolhatnánk, azonban ez a tartomány a reométer szempontjából a méréshatár maximuma, míg a kapilláris viszkoziméter méréshatárának a minimuma. A 31. ábrán ábrázoltam a DWS mérésekből számolt komplex viszkozitás abszolút értékét (zöld négyzet) is. Jól látszik, hogy a nagyfrekvenciás tartományban is érvényes a Cox-Merz szabály.

A különböző reometriai technikákkal megmért dinamikai, illetve komplex viszkozitás abszolút értékek alapján kijelenthetjük, hogy a Cox-Merz szabály közel hat nagyságrendet átfogó frekvencia tartományban elég pontosan teljesül. 


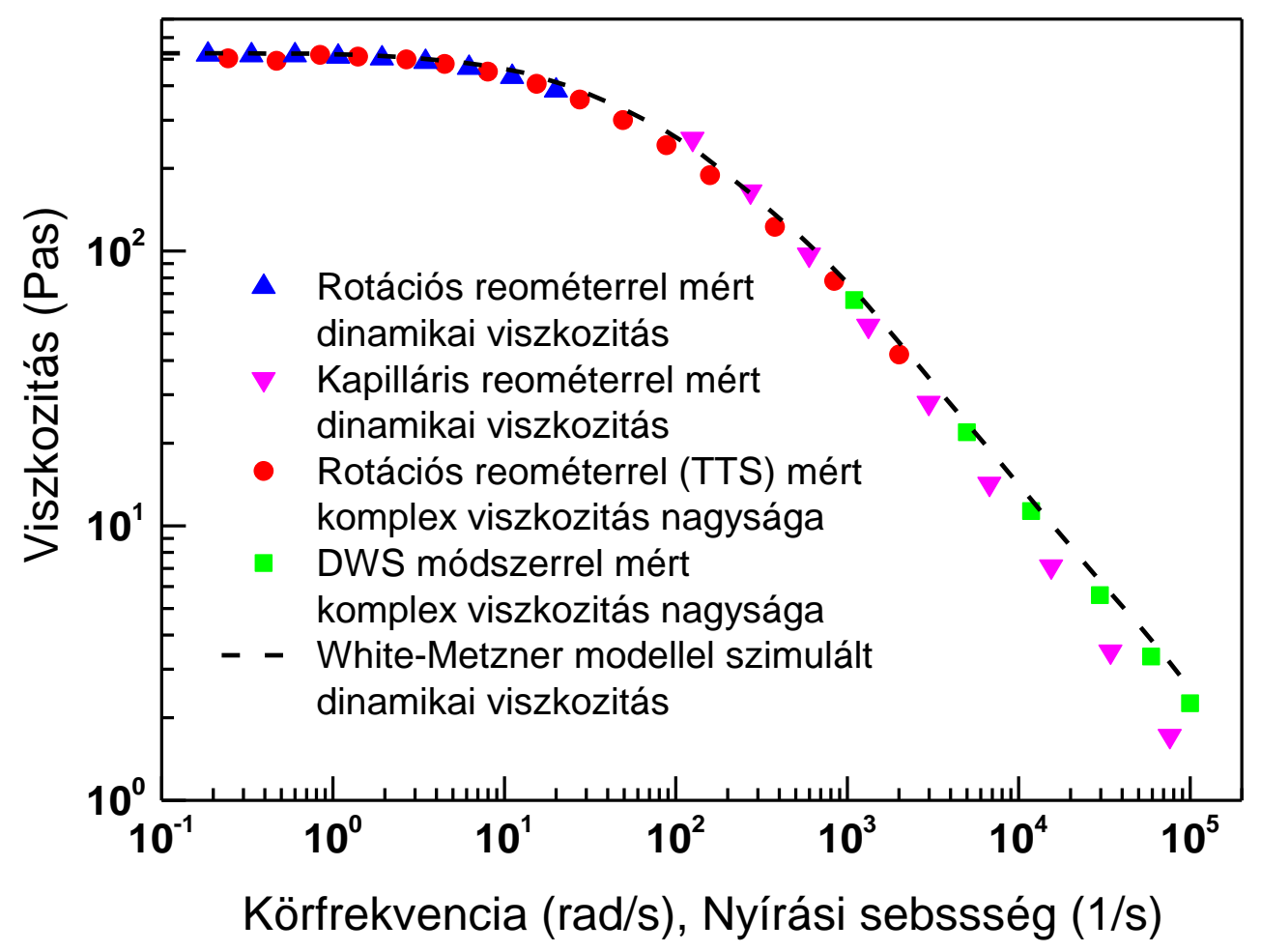

31. ábra: Négyféle mérési módszerrel kapott viszkozitás értékek. Összevetve a rotációs reométerrel kapott viszkozitás értékeket (kék háromszög és piros kör), illetve a DWS spektroszkópiával (zöld négyzet) és kapilláris viszkoziméterrel (lila háromszög) kapott adatokat, megállapítható, hogy a hat nagyságrendet átfogó tartományban a szilikonolajra teljesül a Cox-Merz szabály. A szagatott fekete vonal a hatelemü változó súlyozású White-Metzner-modellel kapott dinamikai viszkozitás értékeket jelöli. 


\subsection{Nemlineáris, változó súlyozású White-Metzner-modell}

Az 5.2 alfejezetben ismertetett állandó súlyozású White-Metzner-modellt továbbfejlesztettük. A SAOS és DWS módszerrel kapott egyesített tárolási és veszteségi modulusz adatokra illesztett hatelemü Maxwell-modellböl indulunk ki. A többelemü White-Metzner-modell konstitúciós egyenletei az alábbi képletek szerint számolhatóak:

$$
\begin{aligned}
& \sigma_{i}(t)+\frac{\tilde{\eta}_{i}(\dot{\gamma}(t))}{g_{i}} \dot{\sigma}_{i}(t)=-\tilde{\eta}_{i}(\dot{\gamma}(t)) \cdot \dot{\gamma}(t), \\
& \sigma(t)=\sum_{i} \sigma_{i}(t),
\end{aligned}
$$

ahol $i=1,2, \ldots, 6$ az elemszám $\dot{\gamma}$ a nyírási sebesség, $\sigma$ a teljes és $\sigma_{i}$ az egy White-Metzner elemre jutó nyírófeszültség, $k_{i}$ pedig a relaxációs modulusz. Az $\tilde{\eta}_{i}$ viszkozitás paramétereknek a nyírási sebességtől való függését a korábbi állandó súlyozással ellentétben az alábbi függvényekkel modelleztük:

$$
\tilde{\eta}_{i}(\dot{\gamma})=\sqrt{\left(\frac{\eta_{i}}{1+\left(\lambda_{i} \dot{\gamma}\right)^{2}}\right)^{2}+\left(\frac{\eta_{i} \lambda_{i} \dot{\gamma}}{1+\left(\lambda_{i} \dot{\gamma}\right)^{2}}\right)^{2}}
$$

Ez a hat elemből álló változó súlyozású White-Metzner-modell már képes pontosan leírni a teljes frekvencia, illetve nyírási sebesség tartományban a jelen munkában eddig ismertetett viszkoelasztikus tulajdonságokat. Ha a nyírási sebesség értékek alacsonyak, akkor a modell a lineáris Maxwel-modellbe megy át, vagyis kis amplitúdójú oszcillációknál a 29. ábrán ábrázolt tárolási és veszteségi modulusokat kapjuk, amelyek tökéletesen illeszkednek a mérési adatokra. Teszteltük a viszkozitás nyírási sebesség függését is. A szimulációs eredményeket a 30. ábrán szaggatott vonallal ábrázoltuk. A modell pontosan leírja az anyag pszeudoplasztikus viselkedését, valamint teljesíti a CoxMerz szabályt a teljes mérési tartományban.

A hatelemű nemlineáris White-Metzner-modell érvényességének vizsgálatát egy további független teszttel is elvégeztem. Ehhez az 5.2 es alfejezetben bemutatott, a rotációs reométeren mért amplitúdó-pásztázó teszteket használtam fel. Mind a tárolási, mind a veszteségi modulusz értékek csökkenése figyelhető meg, ha növeljük az oszcilláció amplitúdóját. Növelve az oszcilláció frekvenciáját a nemlineáris effektus (viszkoelasztikus moduluszok csökkenése) megjelenése egyre kisebb amplitúdóknál jelentkezik. A WhiteMetzner-modell alapján numerikusan szimulált tesztekből számított veszteségi és tárolási 
moduluszok kiválóan illeszkednek a mérési adatokra. A mért és a számított függvényértékeket a kisebb frekvenciák esetén a 32.(a) ábra, míg a nagyobb frekvenciák esetén a 32.(b) ábra szemlélteti.

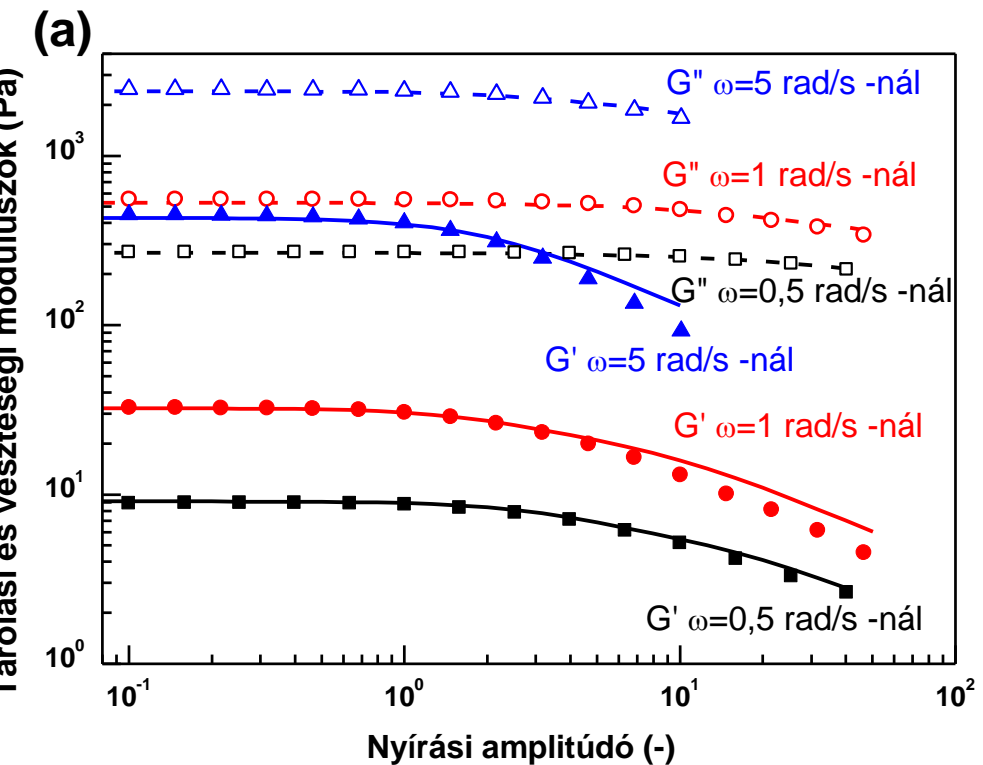

(b)

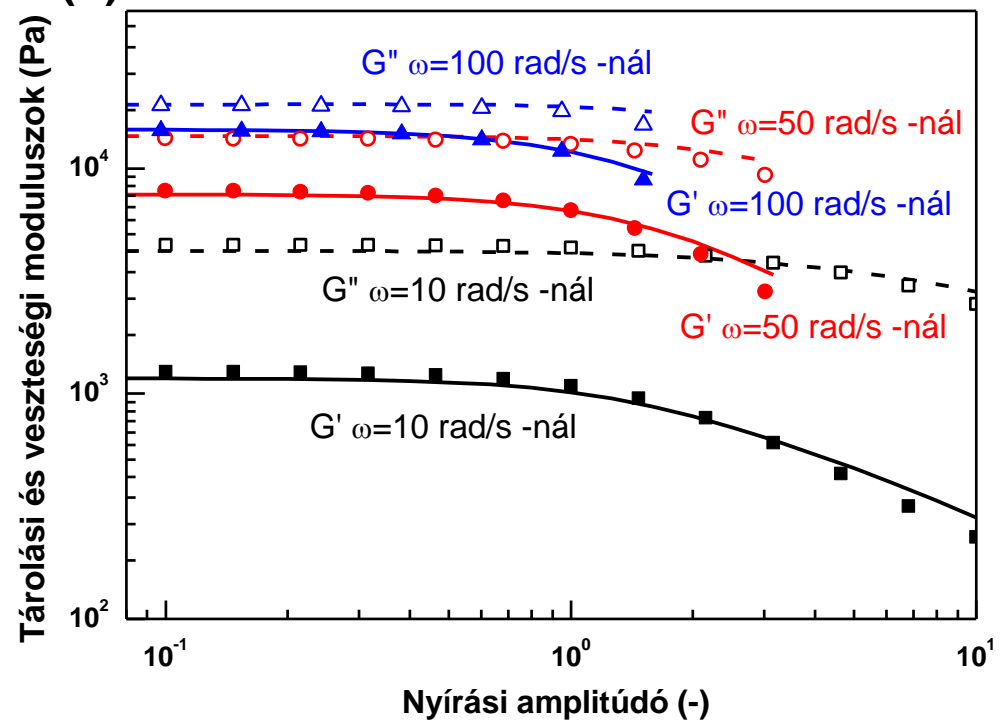

32. ábra: Amplitúdó-pásztázó tesztek mérési eredményeinek (szimbólumok) összevetése a hatelemü nemlineáris White-Metzner-modellel (9. és 10. egyenletek) végzett szimulációs eredményekkel (vonalak), különböző körfrekvencia értékeknél. 


\subsection{LAOS mérések elemzése}

A legalapvetőbb teszt a lineáris és nemlineáris tartomány elkülönítésére az amplitúdó-pásztázó teszt. Ilyenkor a mért nyírófeszültség jel alapharmonikusait $\left(\mathrm{G}_{1}^{\prime} ; \mathrm{G}^{\prime \prime}{ }_{1}\right)$ ábrázoljuk a nyírási amplitúdó függvényében. Ezeket a teszteket az Anton Paar Physica MCR101-es mérőmüszeren mértem, ahol a mérőrendszerből csak a tárolási és veszteségi moduluszok voltak hozzáférhetőek, amelyek a legtöbb esetben, így ezen hagyományos reométernél is, megegyeznek az alapharmonikusokkal $\left(G^{\prime}=G_{1}^{\prime} ; G^{\prime \prime}=G^{\prime \prime}{ }_{1}\right)$. Mérőgeometriának a mérőrendszer bemutatásánál külön bemutatott $\mathrm{CC} 10$-es geometriát használtam. A mérési beállításokat az 5.2 fejezet tartalmazza. Az 5.2 fejezetben, csak a lineáris és nemlineáris tartomány meghatározására használtam az amplitúdó-pásztázó méréseket, most a mérések részletesebb elemzését is ismertetem. A könnyebb átláthatóság kedvéért a mérési eredményeket a 33. ábrán újra ábrázoltuk.

Az amplitúdó-pásztázó teszteink eredményei azt mutatják, hogy a szilikonolaj az összes mért körfrekvencia értéknél nyírásra lágyuló (strain thinning) tulajdonságokat mutat: azaz a tárolási és veszteségi modulusok csökkenek, ha növeljük az oszcilláció amplitúdóját. A körfrekvencia növelésével a nemlineáris tartomány megjelenése mind kisebb és kisebb nyírási amplitúdó értéknél jelentkezik. A 33. ábra mutatja a mért amplitúdó-pásztázó tesztek eredményeit a kiválasztott körfrekvenciáknál, csak azok a mérési pontok vannak ábrázolva, ahol a mérés még megbízható eredményt adott. Az ábráról látható, hogy a körfrekvencia növekedésével ez egyre kevesebb pontot jelent. Ennek oka az, hogy a vizsgált szilikonolaj a Weissenberg-effektus hatására 'kimászik' a mérőtérfogatból, és így már nem ad megbízható eredményt. Az ábra alapján könnyen belátható az ismertetett strain thinning viselkedés. 


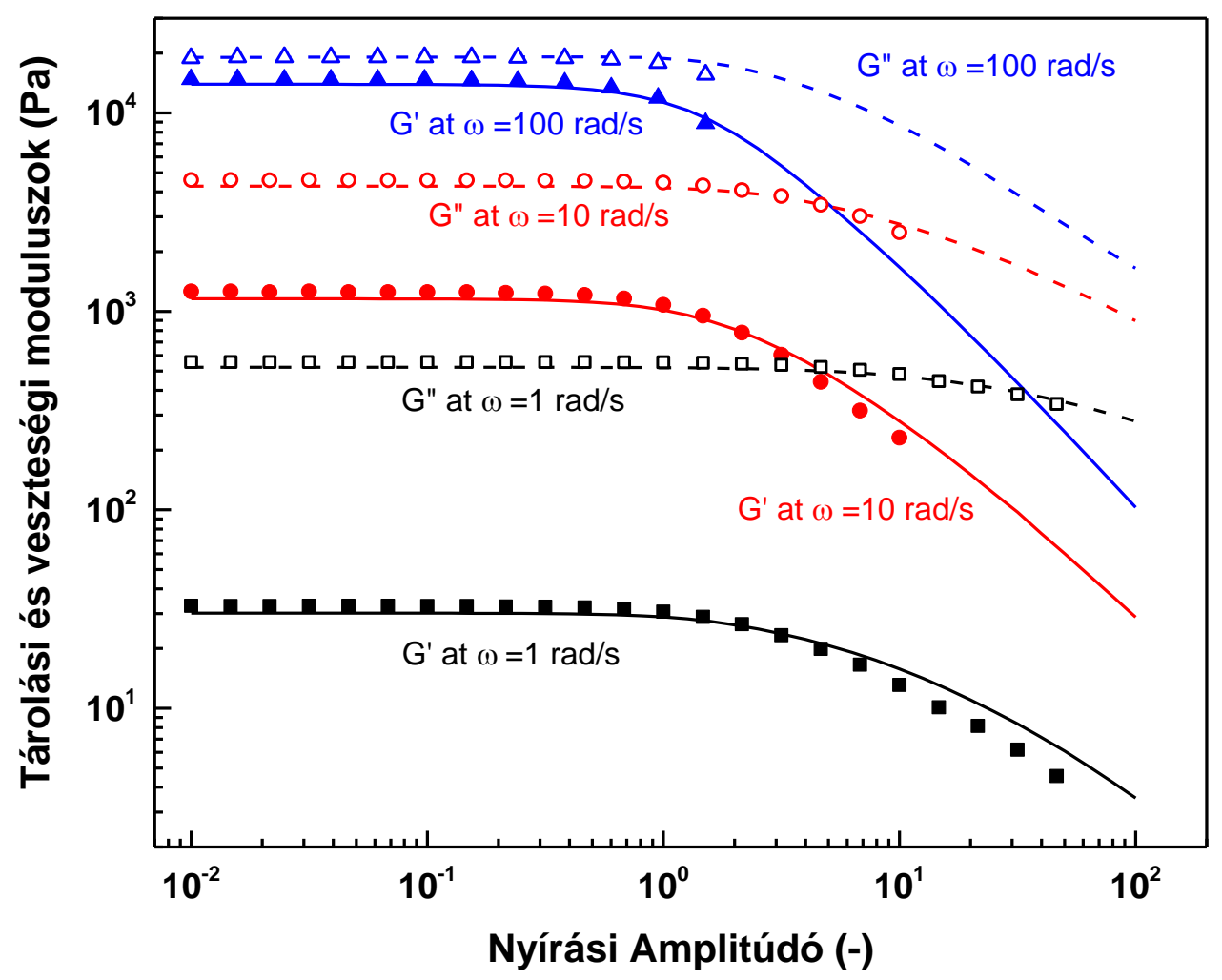

33. ábra: Különböző körfrekvencia értékeknél $(\omega=[1,10,100] \mathrm{rad} / \mathrm{s})$ mért (szimbólumok) és szimulált (vonalak) amplitúdó-pásztázó tesztek eredményei a nyírási amplitúdó függvényében. A mért (számolt) tárolási moduluszokat a teli (folytonos), míg a veszteségi moduluszokat az üres szimbólumok (szaggatott vonalak) jelölik.

A nemlineáris viszkoelasztikus viselkedés az anyag belső szerkezetének átrendeződésével magyarázható. Ha növeljük az oszcilláció amplitúdóját, akkor a PDMS molekulaszálak a nyírási mező irányába próbálnak beállni, így a kezdetben sok csomóponttal rendelkező rendszerben elkezdenek megszünni a csomópontok (kibogozódik a rendszer), miközben az így újonnan létrejött szálaknak már kicsi esélyük van az újbóli összekapcsolódásra, ennek köszönhető a tárolási és veszteségi modulusz csökkenése [38].

Az ábrán az 5.8 alfejezetben bemutatott nemlineáris változó súlyozású WhiteMetzner-modell alapján numerikusan szimulált eredményeket is feltüntettem. A szimulált tárolási moduluszokat folytonos, míg a veszteség moduluszokat szaggatott vonallal ábrázoltam.

Amint azt már többször is említettem célom a szilikonolaj elasztikus és viszkózus nemlineáris viselkedésének mélyebb megismerése. Ennek érdekében igazi LAOS teszteket végeztünk. A mérések Anton Paar Physica MCR702 típusú reométerrel készültek, amely a gyártó legújabb rotációs-oszcillációs reométere, iker motor beépítéssel és magasabb precizitással. Csakúgy, mint az amplitúdó-pásztázó teszteknél, itt is CC10 geometriát 
használtunk, hogy a szilikonolaj ne folyjon ki a mérendő térfogatból. A mért adatok elemzéséhez a gyártó legújabb szoftverét, a RheoCompass programot alkalmaztam, amely képes mind az irodalmi áttekintésben bemutatott Fourier transzformációs reológiai paramétereket $\left(G_{n}^{\prime} ; G^{\prime \prime}{ }_{n}\right)$, mind az Ewoldt és munkatársai által definiált paramétereket kiszámolni $\left(\mathrm{G}_{\mathrm{M}}^{\prime} ; \mathrm{G}_{\mathrm{L}}^{\prime} ; \eta_{\mathrm{M}}^{\prime} ; \eta_{\mathrm{L}}^{\prime} ; S ; T\right)$. A RheoCompass szoftveren keresztül mind a bemenő időfüggő nyírás jelhez, mind a kimenő (mért) időfüggő nyírófeszültség jelhez közvetlenül is hozzá lehet férni.

A nyírásvezérelt LAOS teszteket $\omega=[1,2,5,10,20,50] \mathrm{rad} / \mathrm{s}$ körfrekvencia értékeknél, $\gamma_{0}=[0.1,100]$ nyírási amplitúdó intervallumban, dekádonként 6 pontban, valamint $60 \mathrm{C}$ hőmérsékleten végeztük. Minden egyes mérés során új mintát használtunk, hogy az esetleges belső, mikroszerkezeti anyagi változások ne befolyásolják a mérést. (Megjegyzés: A LAOS tesztek $50 \mathrm{rad} / \mathrm{s}$ körfrekvenciánál magasabb értékre a lineáris tartományon kívül nem adtak értelmezhető eredményt, már a nemlineáris tartomány megjelenése előtt a szilikonolaj 'kimászott' a mérendő térfogatból a Weissenberg hatás következtében.)

A mért nyírófeszültség szemléltetésére a legelterjedtebb módszer, ha LissajousBodwitch görbéken ábrázoljuk a kimenő jelet. A Lissajous-Bodwitch görbék alakjából következtethetünk a vizsgált anyag ciklikusan (intracycle) viszkoelasztikus tulajdonságaira. Az elasztikus Lissajous-Bodwitch görbén a mért nyírófeszültség jelet ábrázoljuk a bemenő nyírás jel szerint, a viszkózus Lissajous-Bodwitch görbén pedig a mért nyírófeszültség jelet ábrázoljuk a bemenő nyírási sebesség jel szerint. 


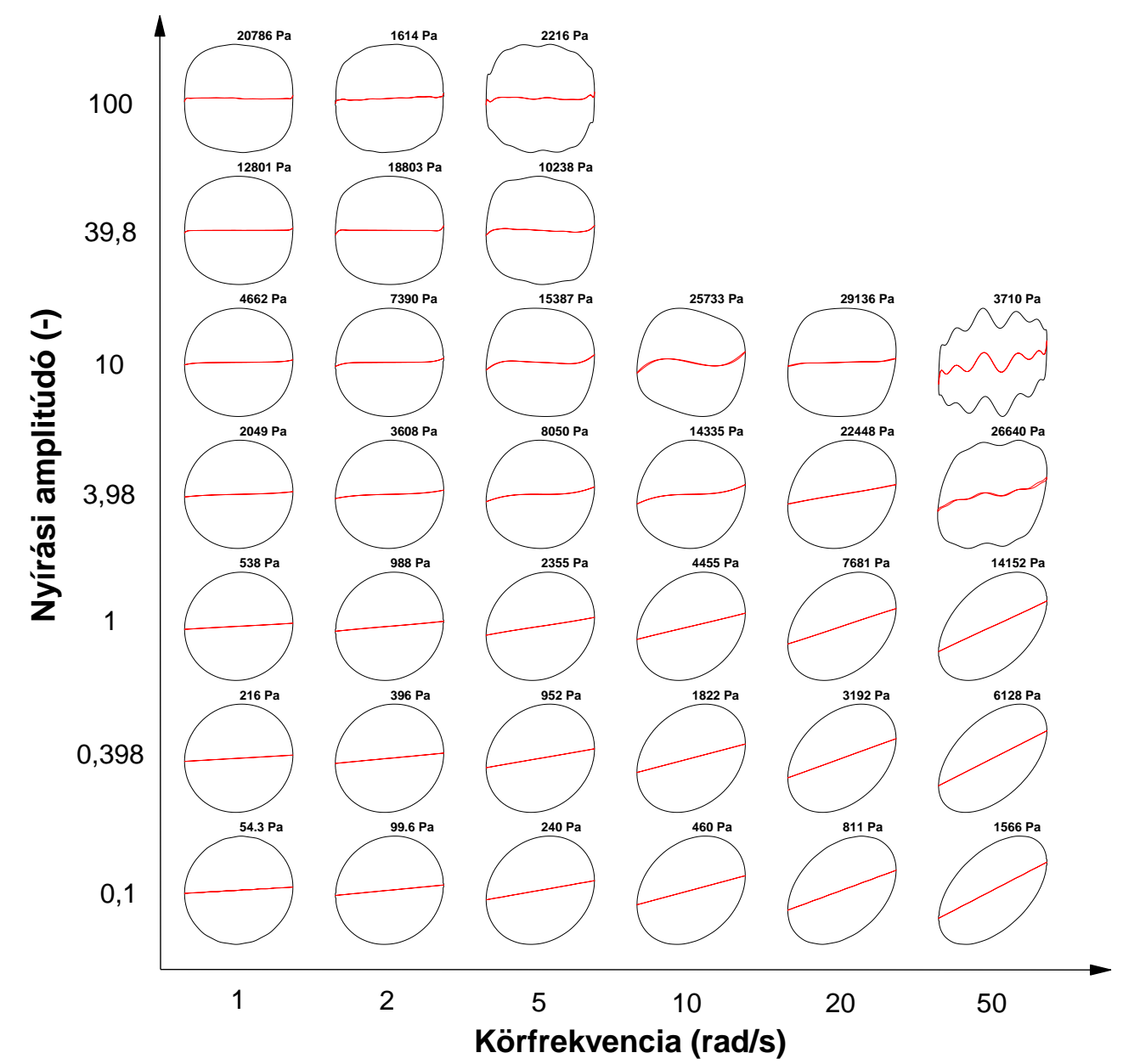

34. ábra: A szilikonolaj LAOS mérési adatainak ábrázolása normált elasztikus Lissajous-Bodwitch görbéken a kiválasztott nyírási amplitúdóknál. A fekete vonalak a mért nyírófeszültséget, míg a piros vonalak az elasztikus nyírófeszültséget jelölik. Az egyes görbék felett a nyírófeszültség maximuma látható.

A 34. ábra mutatja a vizsgált szilikonolajra vonatkozó normált elasztikus LissajousBodwitch görbéket mind a nyírási amplitúdó, mind a körfrekvencia függvényében. Hasonlóképpen a 35. ábra mutatja a normált viszkózus Lissajous-Bodwitch görbéket. Az ábrákon piros vonallal az elasztikus $\left(\sigma^{\prime}\right)$, illetve viszkózus $\left(\sigma^{\prime \prime}\right)$ nyírófeszültség függvényeket is feltüntettem. A Cho-féle nyírófeszültség felbontását a RheoCompass szoftverrel végeztük el. Az egyes görbék felett a mért nyírófeszültség maximumát ( $\left.\sigma_{\text {MAX }}\right)$ is ábrázoltam. 


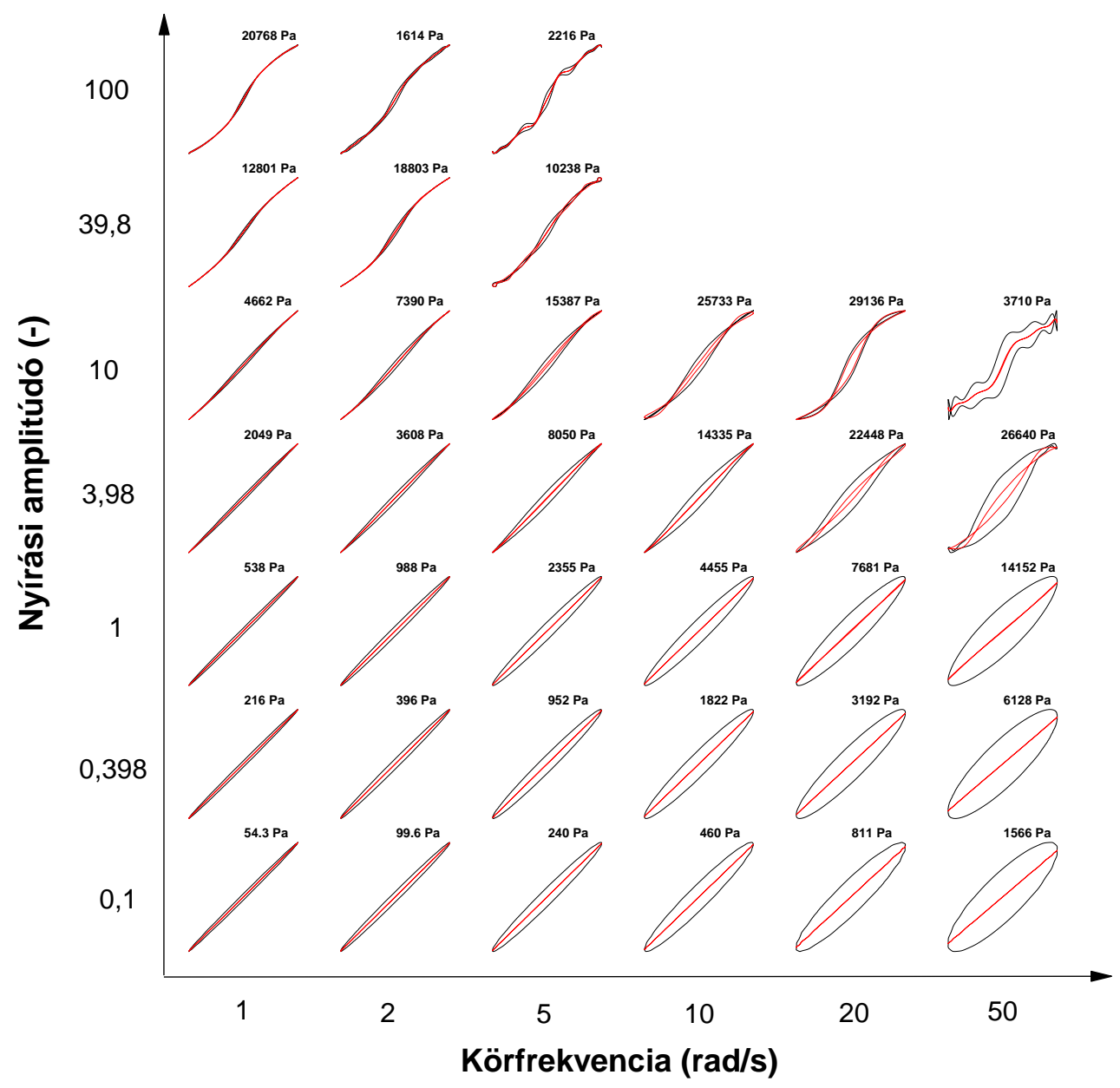

35. ábra: A szilikonolaj LAOS mérési adatainak ábrázolása normált viszkózus Lissajous-Bodwitch görbéken a kiválasztott nyírási amplitúdóknál. A fekete vonalak a mért nyírófeszültséget, míg a piros vonalak a viszkózus nyírófeszültséget jelölik. Az egyes görbék felett a nyírófeszültség maximuma látható.

Az ellipszis alakú Lissajous-Bodwitch görbék, amelyekhez egyenes elasztikus és viszkózus nyírófeszültségek tartoznak, jelzik a lineáris viszkoelasztikus tartományt. Az ellipszistől eltérő alakú Lissajous-Bodwitch görbék, amelyekhez görbült elasztikus és viszkózus nyírófeszültségek tartoznak, a nemlineáris viszkoelasztikus tartományt jelölik. Kis nyírási amplitúdónál $\left(\gamma_{0} \leq 1\right)$ mind az elasztikus, mind a viszkózus görbék ellipszis alakúak, tehát a szilikonolaj ezen pontokban lineáris viszkoelasztikus anyagként viselkedik, amely teljesen összhangban van az amplitúdó-pásztázó tesztek során kapott eredményekkel. A nemlineáris jelleg a magasabb nyírási amplitúdó értékeknél figyelhető meg. A nemlinearitás mértéke nemcsak az amplitúdótól, hanem a körfrekvenciától is függ, amely szintén összhangban van az amplitúdó-pásztázó tesztek során kapott eredményekkel.

Itt külön ki kell térnünk arra, hogy néhány esetben $\left(\left\{\omega, \gamma_{0}\right\}=\{2,100\} ;\{5,39.8\} ;\{5,100\} ;\{50,10\}\right)$ megfigyelhető az, hogy a maximális 
nyírófeszültség értéke csökkeni kezd, ha növeljük a nyírás amplitúdóját, ahelyett, hogy növekedne, mint ahogyan azt előzetesen várnánk. Továbbá ezen mérési eredmények elasztikus és viszkózus Lissajous-Bodwitch görbéi torz alakúak. Ez a jelenség a Weissenberg-effektusnak köszönhető: a szilikonolaj 'kimászott' a mérőhengerből, és így a mért eredmények már nem megbízhatóak, így ezeket nem vesszük bele a további elemzésbe.

A nemlineáris tartományban a nagy viszkozitású PDMS minta az elasztikus Lissajous-Bodwitch görbék alapján ún. ciklikusan nyírásra keményedő (intracycle strain stiffening), míg a viszkózus Lissajous-Bodwitch görbék alapján ún. ciklikusan pszeudoplasztikus (intracycle shear thinning) típusú folyadék. Ha azonban jobban szemügyre vesszük a viszkózus görbéket, azt látjuk, hogy nemcsak a Lissajous-Bodwitch görbékben, hanem a viszkózus nyírófeszültségekben is másodlagos hurkok (secondary loops) jelennek meg. Ez utóbbi annak lehet a következménye, hogy a beállított elvileg tisztán szinuszos nyírás jel valójában már nem tisztán szinuszos. Amennyiben a bemenő nyírás jel nem tisztán szinuszos, úgy a Cho által megadott definíció szerinti nyírófeszültség-felbontás (2.19 és 2.20 egyenlet első fele) nem végezhető el. A RheoCompass szoftver a Fourier transzformációs kifejtést alkalmazza (2.19 és 2.20 egyenlet második fele) az elasztikus és viszkózus nyírófeszültségek meghatározására, ami ilyen esetekben félrevezető. Ha a bemenő nyírás jel nem tisztán szinuszos, akkor nehéz eldönteni, hogy a kimenő nyírófeszültség jel nemlineáris viselkedése mennyiben köszönhető a belső, anyagi nemlineáris viselkedésnek, és mennyiben a bemenő jel nemszinuszos jellegének.

A RheoCompass software segítségével mind a mért kimenő időfüggő nyírófeszültség jelhez mind a bemenő (elvileg tisztán szinuszos) időfüggő nyírás jelhez hozzá tudunk férni. A bemenő nyírás jel nem-szinuszos jellegének elemzéséhez Fourier analízist alkalmaztam:

$$
\gamma(t)=\sum_{n} \tilde{\gamma}_{n} \cdot \sin (n \cdot \omega \cdot t)
$$

Megvizsgáltam azt, hogy hogyan aránylik egymáshoz az $n$-edik harmonikushoz és az alapharmonikushoz tartozó amplitúdó $\left(r_{n 1} \equiv \frac{\widetilde{\gamma}_{n}}{\widetilde{\gamma}_{1}}=\frac{\widetilde{\gamma}_{n}}{\gamma_{0}}\right)$. A beállított nyírási amplitúdó minden estben megegyezett az alapharmonikus tag amplitúdójával. Azt kapjuk, hogy a harmadik felharmonikus tag kivételével a többi felharmonikus aránya (mind a páros, mind 
a páratlan felharmonikus) elhanyagolhatóan kicsi, így ezeket nem vettük bele a további elemzésbe. A 36. ábra mutatja az $r_{31}$ mennyiséget a beállított nyírási amplitúdó függvényében $\left(\gamma_{0}\right)$ az összes vizsgált körfrekvencia értéknél. Azokat a mérési pontokat, ahol a Weissenberg-effektus miatt a szilikonolaj 'kimászott' a mérőtérfogatból, kihagytam az elemzésből.

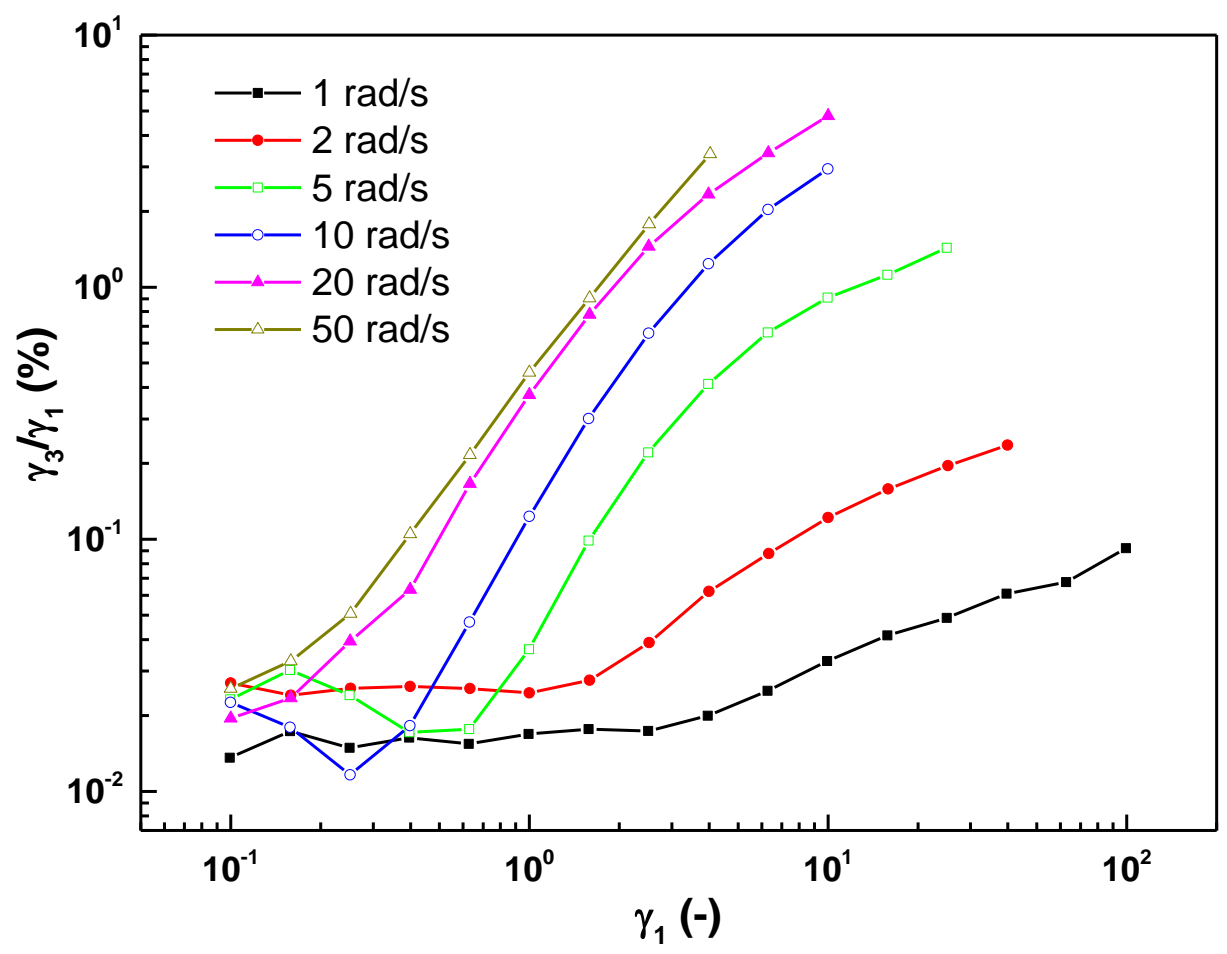

36. ábra: A bemenő nyírás jel harmadik felharmonikusának és alapharmonikusának aránya az alapharmonikus függvényében a különböző mért körfrekvencia értékeknél.

Az ábráról könnyen leolvasható, hogy az $r_{31}$ arány még nagy nyírási amplitúdó és körfrekvencia értékeknél is 5\% alatt van. Tehát a bemenő nyírás jel jó közelítéssel még tisztán szinuszosnak tekinthetö. Ez összhangban van azzal a megfigyeléssel, hogy a 34. ábrán látható elasztikus nyírófeszültségek görbékben nem jelennek meg másodlagos hurkok.

Azonban más a helyzet, ha a bemenő nyírás jelből számolt nyírási sebességet vizsgáljuk. A nyírási sebesség a nyírás idő szerinti deriváltjaként számolható, így az 5.12 egyenlet deriváltjából azonnal adódik, hogy:

$$
\gamma(t)=\sum_{n} \tilde{\gamma}_{n} \cdot n \cdot \omega \cdot \sin (n \cdot \omega \cdot t)
$$

A kapott egyenlet alapján könnyen belátható, hogy a nyírási sebességre definiált arány $\widehat{r_{n 1}} \equiv \frac{\widetilde{\gamma}_{n}}{\tilde{\tilde{\gamma}}_{1}}=\frac{\widetilde{\gamma}_{n}}{\gamma_{0}} \cdot n$, azaz $n$-szer akkora, mint az analóg nyírás jelhez tartozó arány. Így 
azoknál a pontoknál, ahol a bemenő nyírás jel még alig különbözik egy tisztán szinuszos jeltől $r_{31}=5 \%$, a nyírási sebesség jel már lényegesen erösebben $\widehat{r_{31}}=15 \%$ eltér az elvárt tisztán szinuszos jeltöl. Ennek az eltérésnek a következménye az, hogy a 35. ábrán viszkózus nyírófeszültség görbéken másodlagos hurkok figyelhetőek meg. Továbbá a másodlagos hurkok ilyen szembetűnő megjelenését tovább erősíti, hogy a nagy viszkozitású PDMS minta a vizsgált frekvencia tartományban dominánsan viszkózus.

A másodlagos hurkokkal rendelkező elasztikus vagy viszkózus nyírófeszültségeket tartalmazó LAOS mérések elemzésének elmélete jelenleg még nincs kidolgozva. Így ezeket méréseket jelen dolgozatban nem vettem bele a szokásos LAOS elemzésbe.

Jóllehet a nyírási sebesség jel nem tisztán szinuszos, a nyírás, nyírási sebesség és a hozzájuk tartozó nyírófeszültség adatok pontosak és tartalmazzák a nemlineáris viszkoelasztikus információt, ezért továbbra is alkalmasak nemlineáris viszkoelasztikus modellek megalkotására, tesztelésére. A bemenő nem tisztán szinuszos nyírási sebességet tartalmazó adatsorokkal is validálhatjuk a korábbi nemlineáris viszkoelasztikus modellünket. Amennyiben a mért és szimulált eredmények megfelelö egyezést mutatnak, akkor egy virtulis reométerben felhasználva a konstitúciós egyenletet, már ténylegesen tisztán szinuszos bemenő jelekkel szimulációkat végezhetünk a LAOS mérésekre azon frekvenciák és amplitúdók esetén, ahol a modell érvényesnek tekinthető.

Az 5.8 alfejezetben bemutatott konstitúciós egyenletet használtam fel a szimulációkhoz. Az egyenlet egy nemlineáris White-Metzner típusú modell, amely az összefüzött kis amplitúdójú oszcillációs nyírási és DWS tesztek tárolási és veszteségi moduluszaira illesztett hatelemü Maxwell-modell egy lehetséges változata. Ez a konstitúciós egyenlet tökéletesen leírja a nagy viszkozitású szilikonolaj lineáris viszkoelasztikus tulajdonságait, valamint az anyag pszeudoplasztikus (shear thinning) viselkedését.

A szimulációkat a Mathematica (Wolfram Mathematica 9) szoftverrel végeztem, ahol a 'virtuális reométert' az alábbiak szerint terveztem meg. Beállítjuk a kívánt nyírási sebesség jelet, a program megoldja a konstitúciós egyenleteket, majd meghatározza a nyers nyírófeszültség jelet. A definiált konstitúciós egyenletek olyan közönséges differenciálegyenletek, amelyeket numerikus módszerrel célszerü megoldani. A program a bemenő nyírási sebesség és kimenő nyírófeszültség jelből kiszámolja az összes, az irodalmi áttekintésben tárgyalt és általam fontosnak gondolt nemlineáris viszkoelasztikus 
jelleget leíró mennyiségeket $\left(G_{n}^{\prime} ; G_{n}^{\prime \prime} ; G_{M}^{\prime} ; G_{L}^{\prime} ; \eta_{M}^{\prime} ; \eta_{L}^{\prime} ; S ; T\right)$. A bemenő nyírási sebesség függvényt a RheoCompass szoftverből hozzáférhető nyírási sebesség adatok interpolációjaként adtuk meg.

Megjegyzés: Itt kissé zavaró lehet, hogy miért a nyírási sebesség jelet és miért nem a nyírás jelet kell megadni bemenő értékként, hiszen a LAOS teszteknél a nyírás a bemenő jel. Ennek az az oka, hogy a konstitúciós egyenlet direkt módon csak a nyírási sebesség változót tartalmazza. Természetesen a nyírás és nyírási amplitúdók átszámítása igen egyszerü: $\dot{\gamma}_{0}=\gamma_{0} \cdot \omega$.
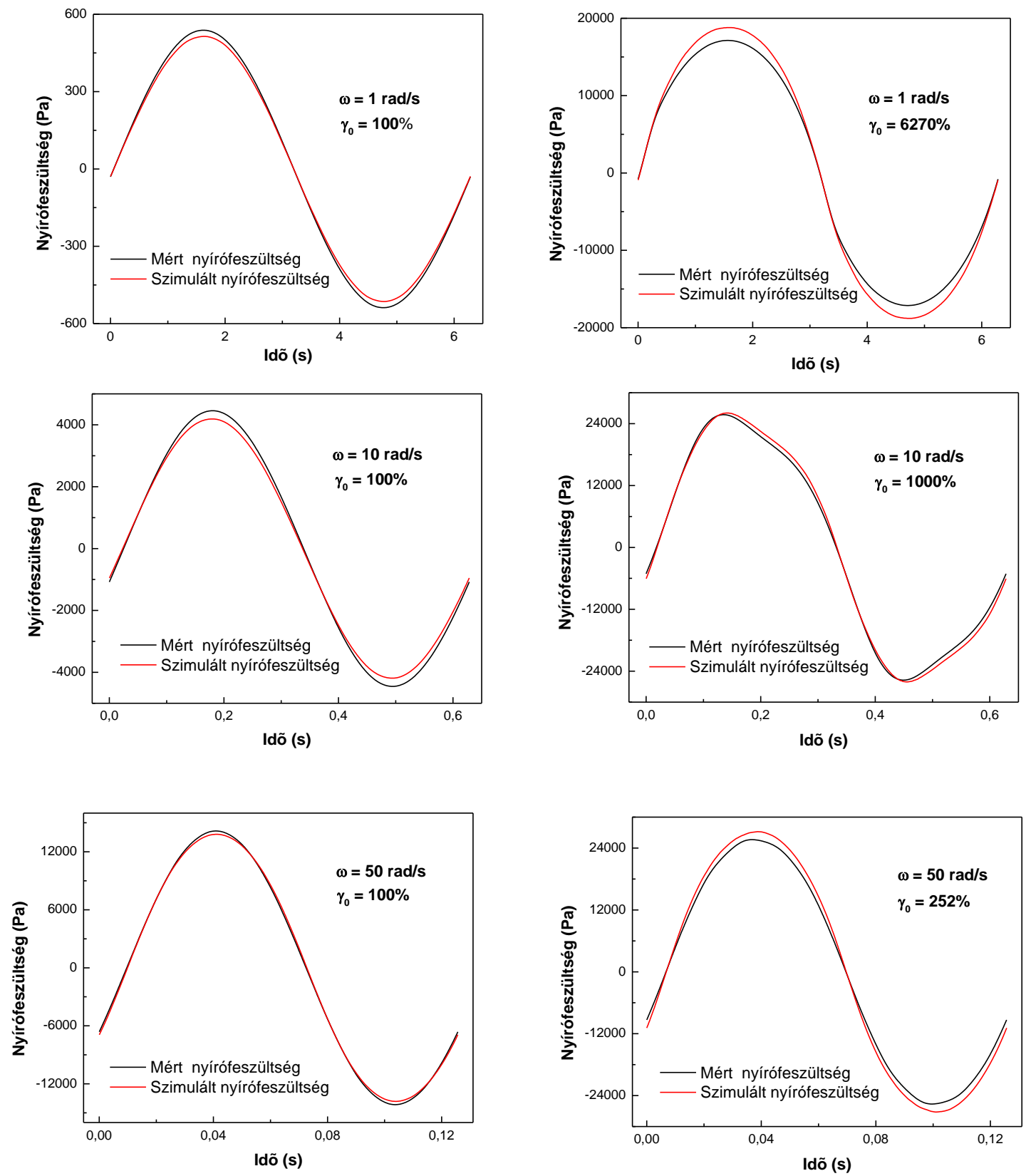

37. ábra: A mért (fekete) és szimulált (piros) nyírófeszültség értékek összevetése az idő függvényében a kiválasztott nyírási amplitúdó és körfrekvencia értékeknél. A bal oldali görbék egy lineáris míg a jobb oldali görbék egy nemlineáris esetet mutatnak. 
Először a nyers időfüggő nyírófeszültség jeleket hasonlítottam össze. A 37. ábra mutatja a kiválasztott nyírási amplitúdóknál (lásd a grafikonok) és körfrekvenciáknál (1, 10, $50 \mathrm{rad} / \mathrm{s}$ ) a mért (fekete görbék) és a szimuláció során kapott (piros görbék) nyírófeszültség függvényeket az idő függvényében. Az egyes frekvenciáknál a bal oldali görbék egy lineáris, míg a jobb oldali görbék egy nemlineáris viszkoelasztikus esetet mutatnak. A szimulált és mért nyírófeszültség jelek még a bemenő erősen nem szinuszos nyírási sebesség jeleknél is igen jól illeszkednek egymásra ( $\omega \geq 10 \frac{\mathrm{rad}}{\mathrm{s}}$ és $\left.\gamma_{0} \geq 398 \%\right)$.

A mérési és szimulációs eredmények összevetésére alkalmasabb, a LissajousBodwitch ábrázolásmód. A 38. ábrán normált elasztikus és viszkózus Lissajous-Bodwitch görbéken ábrázoltuk az 37. ábrán is bemutatott mért és a szimuláció során kapott időfüggő nyírófeszültségeket. A fekete görbék a mért, míg a piros görbék a szimulált eredményeket mutatják. Az ábra alapján látszik, hogy a szimulált és a mért eredmények mind a viszkózus, mind az elasztikus esetekben nagyon jól illeszkednek egymásra. Még a negatív meredekséggel rendelkező elasztikus Lissajous-Bodwitch görbét $\left(\left\{\omega, \gamma_{0}\right\}=\{10,10\}\right)$ is tökéletesen modellezi a White-Metzner típusú konstitúciós egyenlet.
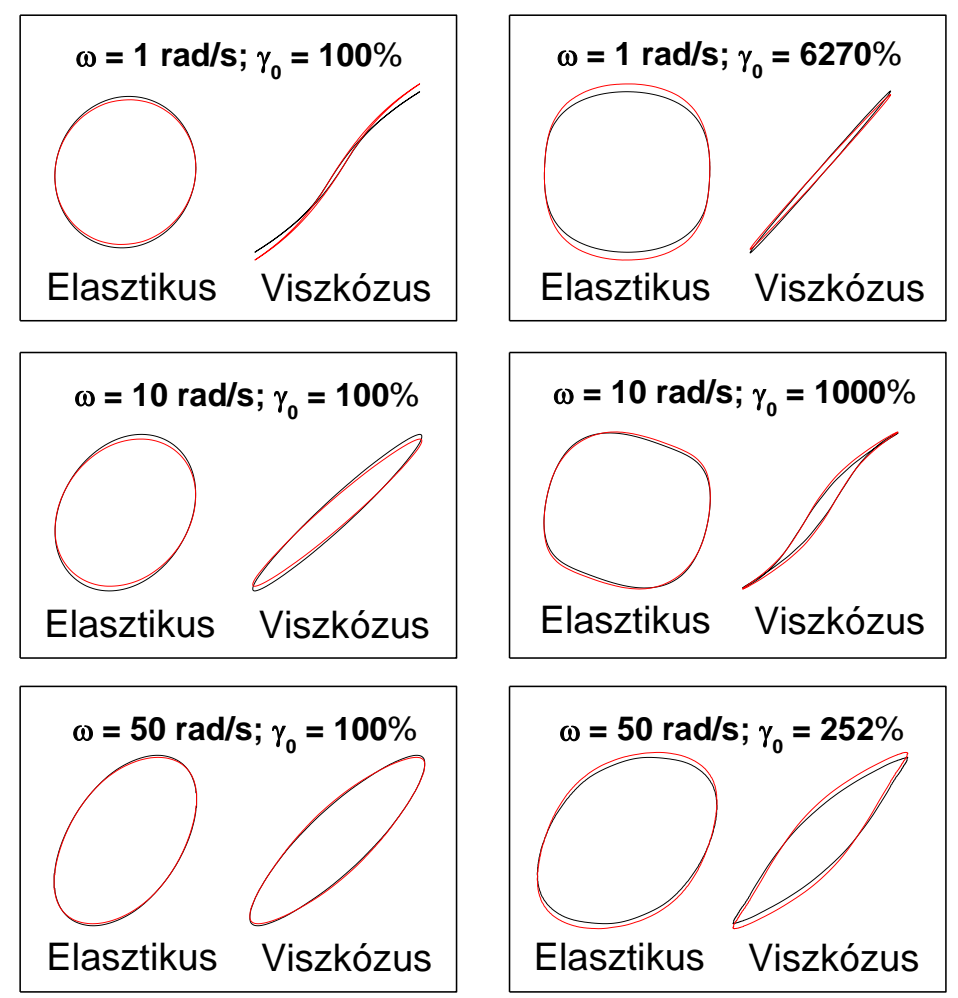

38. ábra: A mért (fekete) és szimulált (piros) nyírófeszültség értékek összevetése LissajousBodwitch görbéken a kiválasztott nyírási amplitúdó és körfrekvencia értékeknél. A bal oldali görbék egy lineáris míg a jobb oldali görbék egy nemlineáris esetet mutatnak. 
Láttuk, hogy a szimulációs során kapott eredmények minden esetben nagyon jól illeszkednek a mérési adatokra. Ebből adódóan a konstruált változó súlyozású konstitúciós egyenletek (5.10 és 5.11 egyenlet) tökéletesen leírják az AK1.000.000 típusú szilikonolaj reológiai tulajdonságait mind a lineáris, mind a nemlineáris tartományban.

Ahhoz, hogy teljesebb képet kapjunk az anyag nagy amplitúdójú oszcillációs nyírási viselkedéséről, a LAOS szimulációk körfrekvencia tartományát $\omega=600 \mathrm{rad} / \mathrm{s}$-ig, míg a nyírási amplitúdót $\gamma_{0}=100$-ig terjesztettük ki. A bemenő nyírási sebesség jelet mindenhol szigorúan szinuszosnak választottuk. Ezeket a szimulációs eredményeket két dologra használtam:

- Egyrészt, azon LAOS mérési adatokat helyettesítettem, amelyek a fent leírt okok miatt nem voltak alkalmasak a további LAOS elemzésre. (A minta kimászott a mérőtérfogatból a Weissenberg-effektus miatt, vagy pedig a bemenő nyírási sebesség jel többé már nem volt tisztán szinuszos.)

- Másrészt, abban a körfrekvencia és nyírási amplitúdó tartományban, ahol egyáltalán nem voltak mérések, a szimulációs eredmények alapján előre jelezzük, „felderítjük” a PDMS minta várható nemlineáris viszkoelasztikus jellemzőit. A szimulált körfrekvencia tartomány kiterjesztésére azért volt szükség, hogy a minta teljes LAOS alapú jellemzését megadhassuk, amihez mind a keresztezési körfrekvencia (crossover frequency, $\left.\omega_{\mathrm{CO}}=210 \mathrm{rad} / \mathrm{s}\right)$ alatt, mind a felett ismernünk kell az anyag viselkedését.

A tisztán szinuszos nyírási sebességgel szimulált LAOS teszteket $\omega=[1,2,5,10,20,50,100,200,400,600] \mathrm{rad} / \mathrm{s}$ körfrekvencia értékeknél és $\gamma_{0}=[0.1,100]$ nyírási amplitúdó intervallumban, dekádonként 6 pontban, futtattuk le. Az együttes mért és szimuláció során kapott eredményeket Pipkin diagramokon ábrázoltuk [28]. A 39.(a) és 40.(a) ábrák a Fourier együtthatókból számolható elasztikusságra jellemző $\mathrm{e}_{3} / \mathrm{e}_{1}$ és a viszkózusságra jellemző $\mathrm{v}_{3} / \mathrm{v}_{1}$ hányadosok Pipkin diagramjait mutatják. A 39.(b) és 40.(b) ábrák az Ewoldt és munkatársai által definiált elasztikusságra jellemző $S$ és a viszkózusságra jellemző $T$ paraméterek Pipkin diagramjait mutatják be. 

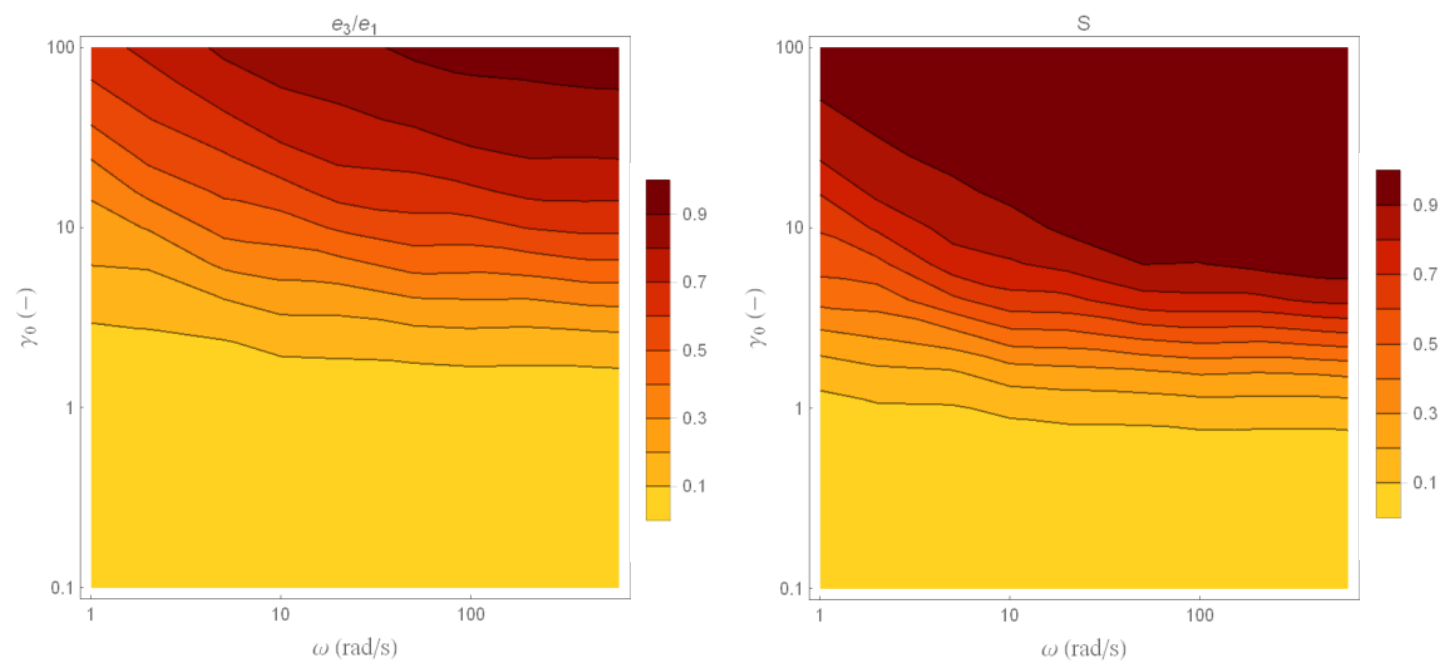

39. ábra: Az együttes mért és szimulációs adatok alapján számolt $\mathbf{e}_{3} / \mathrm{e}_{1}$ és $\mathrm{S}$ elasztikus tulajdonságot jellemző paraméterek Pipkin diagramjai. Az egyre pirosodó sávok a nemlineáris viselkedés fokozatos erősödését jelzik.
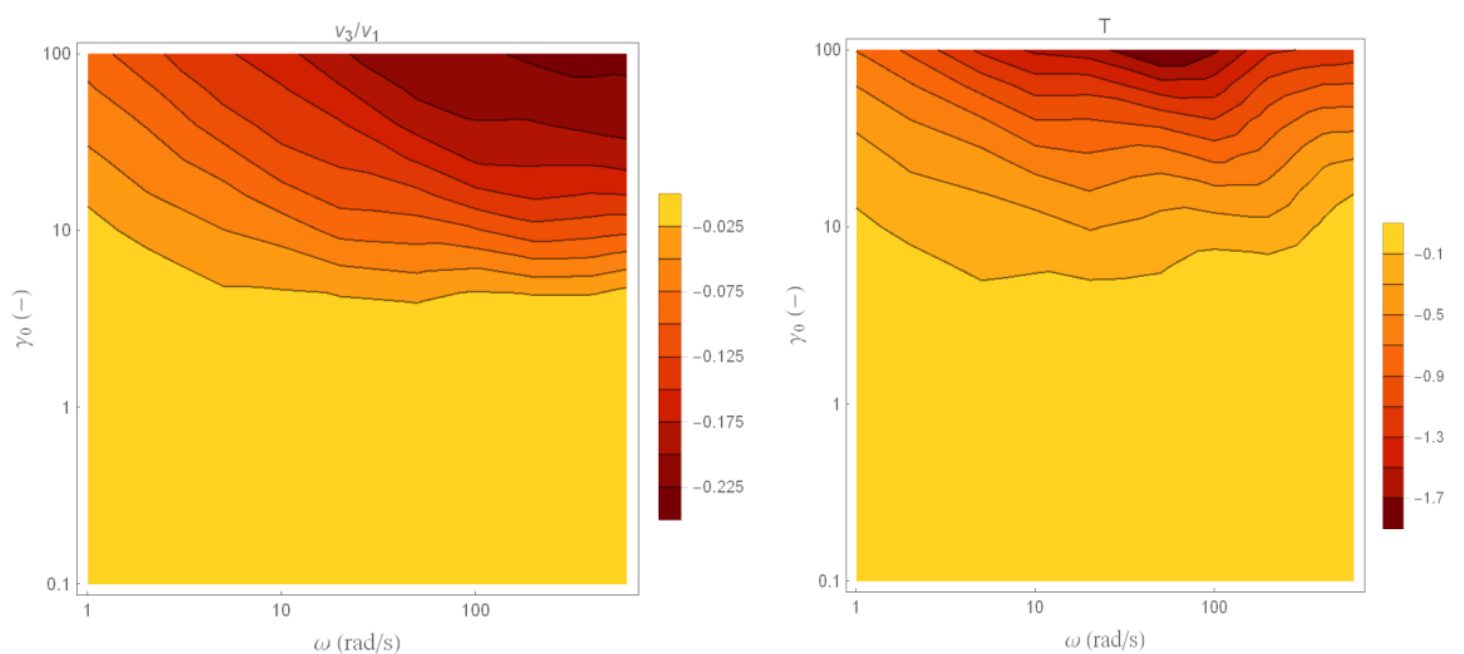

40. ábra: Az együttes mért és szimulációs adatok alapján számolt $v_{3} / v_{1}$ és $T$ viszkózus tulajdonságot jellemző paraméterek Pipkin diagramjai. Az egyre pirosodó sávok a nemlineáris viselkedés fokozatos erősödését jelzik.

$\mathrm{Az}$ ábrákon lévő sárgától pirosba átmenő terület jól mutatja a nemlineáris viselkedés fokozatos erősödését. A nemlineáris tartományban az elasztikus Pipkin diagramok (39. ábra) alapján a nagy viszkozitású PDMS minta ciklikusan nyírásra keményedő (intracycle strain stiffening) $\left(\mathrm{e}_{3} / \mathrm{e}_{1}>0, \mathrm{~S}>0\right)$ anyagként, valamint a viszkózus Pipkin diagramok (40. ábra) alapján ciklikusan pszeudoplasztikus (intracycle shear thinning) $\left(\mathrm{v}_{3} / \mathrm{v}_{1}>0, \mathrm{~T}>0\right)$ anyagként viselkedik. A nyírási amplitúdó növelésével a nemlinearitás is egyre nő függetlenül az alkalmazott körfrekvenciától. A nemlineáris elasztikus viselkedés már alacsonyabb nyírási amplitúdó értékeknél és meredekebben kezd megjelenni, mint a nemlineáris viszkózus viselkedés. Mivel a vizsgált szilikonolaj dominánsan viszkózus a keresztezési körfrekvencia alatt, ezért biztosan állítható, hogy a 
szilikonolaj nyírófeszültség válasza 100\%-os nyírási amplitúdó és 100 rad/s körfrekvencia alatt lineáris.

Összevetve az $S$ és $T$ paraméterek illetve az $\mathrm{e}_{3} / \mathrm{e}_{1}$ és $\mathrm{v}_{3} / \mathrm{v}_{1}$ paraméterek körfrekvencia és nyírási amplitúdó függését, megállapítható, hogy habár vannak tartományok, ahol az elasztikus és viszkózus jelleget leíró paraméterek hasonló alakúak, azonban vannak, olyan tartományok ahol jelentősen különböznek. Ennek oka, hogy az $S$ és $T$ paraméterek a magasabb rendü felharmonikusok hatását is tartalmazzák. A szilikonolaj egy olyan anyag, amely már ebben a tartományban is erösen nemlineáris, azaz a csak a 3. felharmonikusok figyelembevétele nem elegendő, így a további megállapításokhoz az $S$ és $T$ Pipkin diagramokat vizsgáljuk.

Két sajátos viselkedés olvasható le a Pipkin diagramokról:

- A T paraméternek van egy maximuma $\omega=50 \mathrm{rad} / \mathrm{s}$ körfrekvencia érték körül. A szilikonolaj válasza egyre inkább lineárissá válik viszkózus szempontból, ezen frekvencia alatt és felett.

- Az S paraméter $\omega=30 \mathrm{rad} / \mathrm{s}$ körfrekvencia érték felett gyakorlatilag körfrekvencia függetlenné válik (a szintvonalak vízszintesek), vagyis ebben a tartományban az elasztikus értelemben vett nemlinearitás csak a nyírási amplitúdótól függ (minél nagyobb az amplitúdó, annál nagyobb az elasztikus nemlinearitás). $\omega=30 \mathrm{rad} / \mathrm{s}$ körfrekvencia érték alatt a szilikonolaj úgy viselkedik, mint ahogyan előzetesen várjuk: minél nagyobb a körfrekvencia és a nyírási sebesség annál nagyobbá válik az elasztikus nemlinearitás. 


\subsection{Térfüggö viszkoelasztikus anyagi egyenlet és tesztelése}

A reométeres mérések során a szilikonolaj jó közelítéssel az előírt nyírási deformációt hajtja végre, azonban a szilikonolaj alkalmazásai esetében általában összetettebb áramlás alakul ki. Utóbbi esetek leírására a koncentrált paraméterü modell jellemzően nem, vagy csak durva közelítéssel alkalmas, ezért a térfüggő áramlástani egyenletek megoldásához térfüggő konstitúciós egyenletre van szükség. Az ilyen egyenletek megadására nemlineáris viszkoelasztikus anyagok esetén jelenlegi tudásunk szerint nincs pontos, általánosan használható módszer, csak bizonyos előírásoknak kell eleget tenni, amelyek megmaradási tételekből levezethetőek. A térfüggő anyagi egyenletekkel kiegészített áramlástani egyenletek bonyolult nemlineáris parciális differenciálegyenlet-rendszert alkotnak, melyeknek a valódi geometriai feltételek által meghatározott áramlási térben történő megoldására általában csak numerikus módszerekkel van lehetőség. Erre széles körben használható a végeselemes módszer (FEM), amelynek alapjait már ismertettem a 2.7 alfejezetben.

A 2.6 alfejezetben azt is áttekintettem, hogy a koncentrált paraméterü modellből milyen matematikai módszerekkel lehet olyan térfüggő anyagi egyenletet létrehozni, amely nagy deformációk esetén is érvényes. Első lépésként mi is ezt tesszük, természetesen a legegyszerűbb lehetőséget választva. Ezután a konkrét reométeres mérésekhez használt mérő geometriát modellezve, két esetben használom a térfüggő konstitúciós egyenletet végeselemes szimulációkhoz. A CP geometria esetén lehetőség van az állandó nyírási sebességü mérés esetén a forgástengely irányában kialakuló nyomóerő (normal force) mérésére, ezért ennek a modellezésével kapott szimulációs eredmények összevetése a mért értékekkel a térfüggő modell helyességének egyik fontos tesztje. A CC geometria szimulációja két szempontból is fontos: ebben az esetben tesztelni tudom egyrészt azt, hogy a szabad folyadékfelszín, azaz a szilikonolaj-levegő határfelület deformációja szempontjából is összhangban van-e a modell a valósággal, másrészt a szimulációk segítségével ki tudom számítani, hogy a Weissenberg-effektus mennyire befolyásolja az állandó nyírási sebességü mérések pontosságát.

\subsubsection{A térfüggö White-Metzner-modell egyenletei}

Az 5.8 alfejezetben ismertetett, koncentrált paraméterü, változó súlyozású WhiteMetzner-modell térfüggő általánosítására a legegyszerübb lehetőség a nyírófeszültség idő 
szerinti deriváltjának az úgynevezett upper-convected deriválttal történő helyettesítése, amely az alábbi térfüggő egyenletet adja a többelemü modell $j$. eleme által leírt feszültségtenzorra vonatkozóan:

$$
\underline{\underline{\sigma}}_{j}+\frac{\bar{\eta}_{j}(\underline{\dot{\gamma}})}{k_{j}} \underline{\underline{\sigma}}_{j}=-\bar{\eta}_{j}(\underline{\dot{\gamma}})\left(\nabla \underline{\mathrm{v}}+(\nabla \underline{\mathrm{v}})^{T}\right)
$$

ahol az upper-convected (továbbiakban UC) deriváltat az alábbi formula definiálja:

$$
\underline{\underline{\sigma}}_{j}=\frac{\partial \underline{\underline{\sigma}}_{j}}{\partial t}+(\underline{\mathrm{v}} \cdot \nabla) \underline{\underline{\sigma}}_{j}-\left[\underline{\underline{\sigma}}_{j}(\nabla \underline{\mathrm{v}})+\left(\nabla \underline{\mathrm{v}}^{T} \underline{\underline{\sigma}}_{j}\right]\right.
$$

A fenti két egyenletben $\underline{\mathrm{v}}$ az áramlási sebességmező, ami természetesen függ a helytől és az időtől, akárcsak a $\underset{\underline{\sigma}}{\sigma}$ feszültség-tenzorok és a $\underset{\gamma}{\dot{\gamma}}$ nyírási sebesség tenzor. A teljes viszkoelasztikus feszültség-tenzor természetesen továbbra is az elemenként kapott feszültség-tenzorok összege:

$$
\underline{\underline{\sigma}}=\sum_{j=1}^{n} \underline{\underline{\sigma}}_{j}
$$

A fenti konstitúciós egyenletek jól láthatóan csatolva vannak az áramlási térhez a sebességmezőn keresztül már abban a speciális esetben is, ha a viszkozitás nem függ a nyírási sebességtől. A sebességmezőt természetesen az alábbi egyenletek határozzák meg:

$$
\begin{aligned}
& \rho \frac{\partial \underline{\mathrm{v}}}{\partial t}+\rho(\underline{\mathrm{v}} \cdot \nabla) \underline{\mathrm{v}}=\nabla \cdot[-p \underline{\underline{I}}+\underline{\underline{\sigma}}]+\underline{\mathrm{f}}, \\
& \frac{\partial \rho}{\partial t}+\nabla \cdot(\rho \underline{\mathrm{v}})=0 .
\end{aligned}
$$

Itt $\rho$ a sűrüség, $p$ a nyomás, $\underline{\mathrm{f}}$ pedig az egyéb erők térfogati erő-sűrüsége, pl. a nehézségi erő esetében a szokásos nehézségi gyorsulás és a sürüség szorzata: $\underline{\mathrm{f}}=\rho \underline{\mathrm{g}}$.

Az 5.14-16 konstitúciós egyenletek azonban a viszkozitásnak a nyírási sebességtől való $\bar{\eta}_{j}(\underset{\gamma}{\underline{\gamma}})$ függésén keresztül is csatolva vannak az áramlási térhez, a nyírási sebesség pedig jelen esetben már szintén egy másodrendü tenzor. Számos lehetőség van arra, hogyan általánosítsuk a változó súlyozású White-Metzner-modell 5.11 formulával megadott viszkozitás függvényét. Mi az egyik legegyszerübbet választottuk: a koncentrált paraméterü modell nyírási sebességét a térfüggő nyírási sebesség tenzor Hilbert-Schmidt 
normájával arányos skaláris mennyiséggel helyettesítettük, amely természetesen továbbra is függ a helytől és az időtől is:

$$
\bar{\eta}_{j} \underset{=}{(\dot{\gamma})}=\tilde{\eta}_{j}(\|\dot{\gamma}\|), \text { ahol }\|\dot{\gamma}\|=\sqrt{\frac{1}{2} \operatorname{Tr}\left[\underline{\dot{\gamma}}^{2}\right]}
$$

Mivel mindkét modellezni kívánt geometria forgásszimmetrikus, célszerü a fenti egyenleteket hengerkoordinátákban használni. A rotációs reométer által létrehozott áramlás fontos jellemzője továbbá, hogy a fizikai mennyiségek hengerkoordinátákban nem függnek az azimutális szögtől, ami egyrészt jelentősen egyszerüsíti a mozgásegyenleteket, másrészt lehetővé teszi, hogy a háromdimenziós geometria helyett annak kétdimenziós tengelymetszetét modellezzem.

A fenti egyenletek megoldásához természetesen kezdeti és peremfeltételekre is szükség van. Mivel a modellezett reométeres mérés is álló helyzetből indul, természetes kezdeti feltétel, hogy a sebességtér mindenütt zéró, ennek megfelelően a feszültségtenzor minden komponense is zéró, a nyomás pedig az egyszerü hidrosztatikai nyomás. A sebességtér peremfeltételeit a szilikonolajnak a reométer mérőgeometriájával érintkező felületein az azimutális irányban megszabja a reométer által elöírt kinematika, a másik két irányban általában 0 sebességet adunk meg. (Utóbbi alól kivétel lesz a CC geometria esetében néhány peremfeltétel, erre ott kitérünk majd.) Mindkét geometria esetében marad egy peremfelület, ahol a valóságban a szilikonolaj a levegővel érintkezik, itt CP geometria esetén elöírt sebességet alkalmazunk, CC geometria esetén viszont a levegöt is a modell részének tekintjük, amint ezt majd ott részletezzük. A feszültségtenzorra vonatkozóan nincs szükség külön peremfeltételek előírására, mert a sebességtér és annak peremfeltételei már meghatározzák a feszültségtér dinamikáját.

\subsubsection{CP méröfej végeselemes szimulációja}

A CP geometriával történő állandó nyírási sebességü mérés modellezésével a fő célom a térfüggő konstitúciós egyenlet tesztelése volt: a forgástengely irányában kialakuló nyomó-erő szimulációval kapott értékeinek összehasonlítása a mért értékekkel a térfüggő modell egyik fontos tesztje.

A $25 \mathrm{~mm}$ átmérőjü CP25 kúp-lap geometria (kúpszöge mindössze $1^{\circ}$ ) Comsolban megalkotott tengelymetszeti modelljét a 41. ábrán mutatom be. A kék színnel jelölt 
tartományt tölti ki a szilikonolaj, itt fejtik ki hatásukat az 5.14-19 egyenletek. Ez a kétdimenziós tartomány tehát a bal szélén piros színnel jelölt forgástengely körüli $360^{\circ}$-os körbeforgatásával kapható forgásszimmetrikus térfogatot reprezentálja hengerkoordinátákban, ennek megfelelően a tartomány fekete, zöld és narancssárga színnel jelölt peremei a valóságban forgásszimmetrikus felületek. A forgástengely egyben a hengerkoordináta rendszer $z$ tengelye. A fekete színnel jelölt alsó perem a mérőgeometria sík lapját jelenti, itt a sebességmező minden komponense zéró. A narancssárga színnel jelölt felső perem a mérőgeometria kúpos lapját jelöli, a mérés során ez forog a beállított nyírási sebességnek megfelelő szögsebességgel, ennek megfelelően van elöírva a sebességmező azimutális komponense, a másik két komponens zéró. A jobb oldali, zöld színű perem a valóságban a szilikonolaj és a levegő határfelülete. (Mivel ez csak kb. 0,2 mm magas, a felületi feszültség megtartja az olajat.) Ezen a felületen a sugárirányú sebességkomponens zéró, a függőleges sebességkomponens nincs elöírva, az azimutális sebességkomponens pedig az elöírt nyírási sebességnek megfelelően van beállítva. A nyomás zéró értékét a jobb alsó csúcsnál rögzítettem.

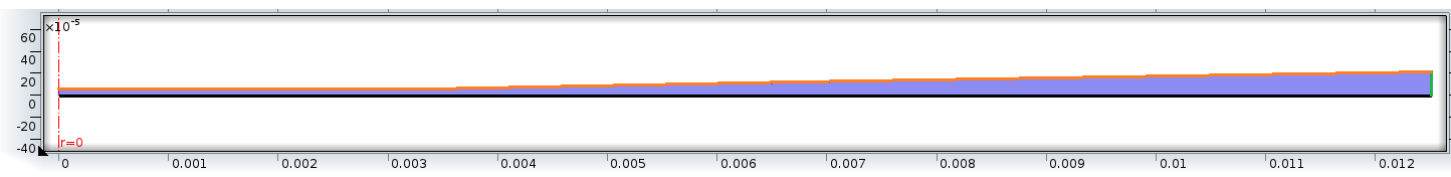

41. ábra: A CP25 geometria Comsolban megalkotott modellje

A végeselemes hálóhoz az áramlástani szimulációkhoz használatos módszert választottam. A kész hálót, amely egy határréteg- és egy háromszög-háló összeillesztése, a 42. ábrán szemléltetem, a tartomány két végéről készített képpel.
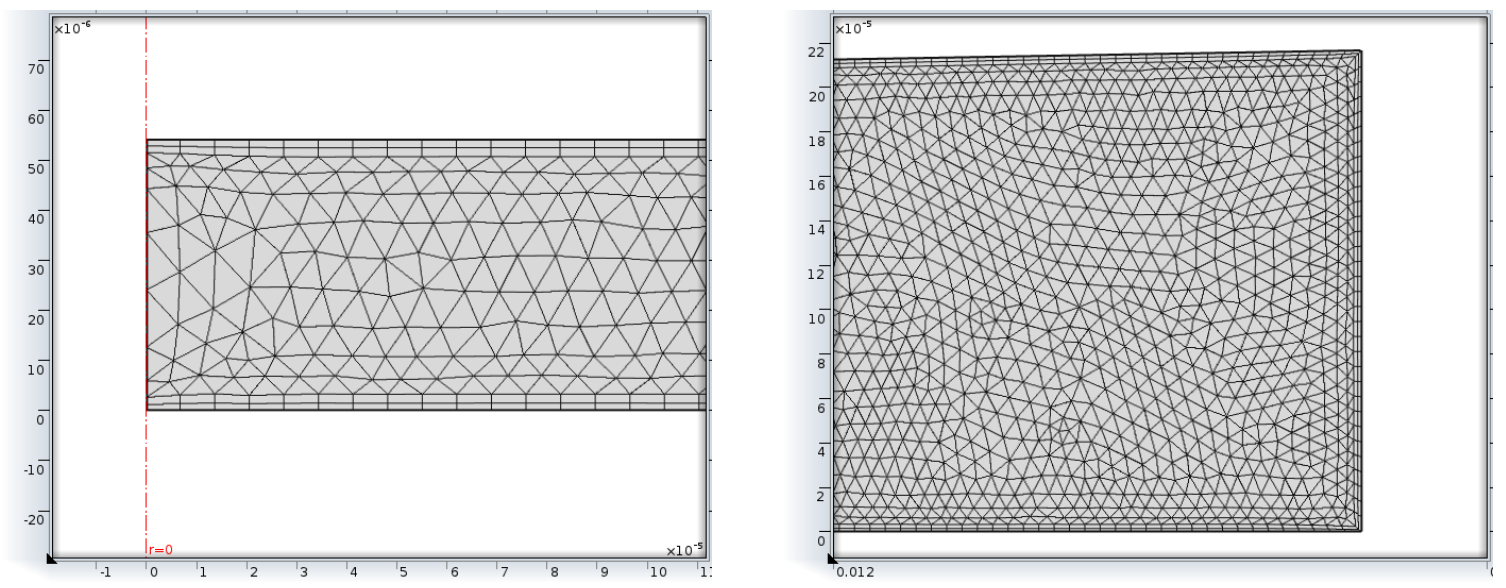

42. ábra: A CP25 geometria végeselemes hálója a szimulációs tartomány bal illetve jobb oldalán 
Az időfüggő szimulációk során az elöírt nyírás sebességet egyenközü lépcsőkben, sima időfüggéssel változtattam, pl. a 43. ábra szerint, elég időt hagyva arra, hogy stacionárius állapot alakuljon ki minden lépcső esetén.

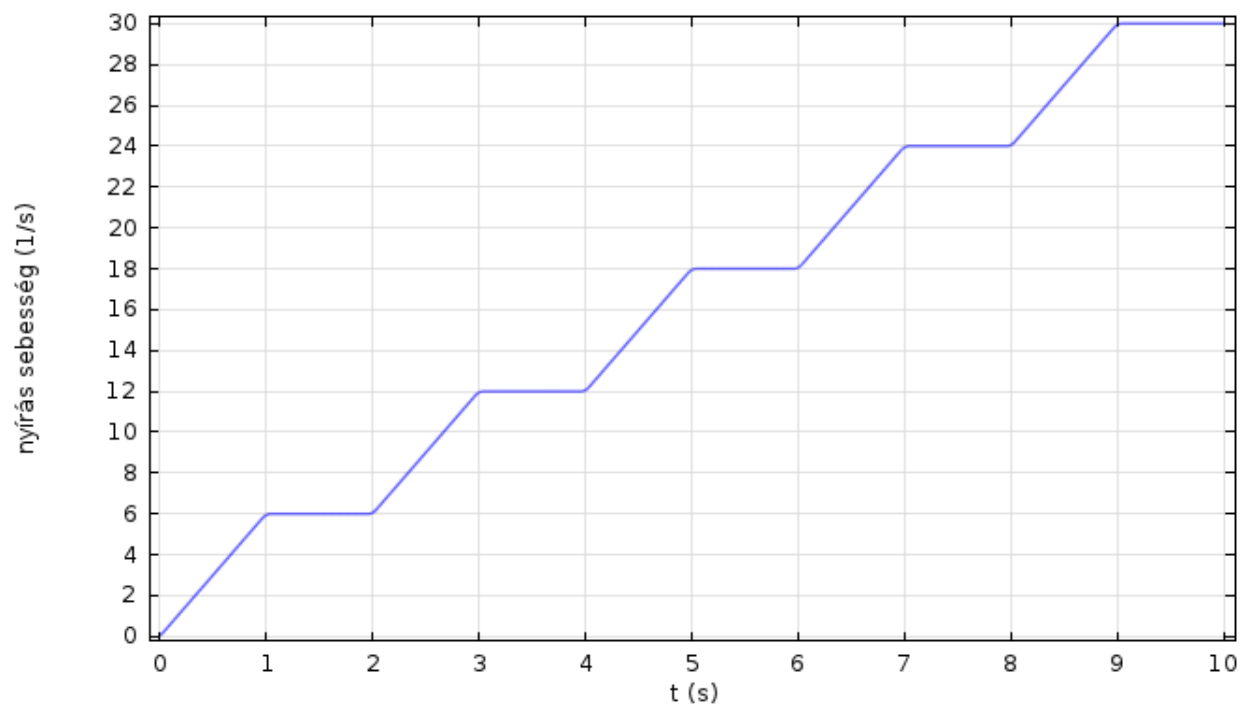

43. ábra: A CP25 geometria szimulációja során alkalmazott előírt nyírási sebességek tipikus időfüggése

A szimuláció közvetlen eredményeit a 44. ábrán szemléltetjük, (a) a nyomás, valamint (b) a $\sigma_{\varphi z}$ viszkoelasztikus nyírófeszültség komponens színkódolt függvényével, $301 / \mathrm{s}$ beállított nyírási sebességnek megfelelő értéknél. A $\sigma_{\varphi z}$ helyfüggése a várt profilt mutatja, a nyomás jelentős radiális helyfüggését viszont már a nemlineáris viszkoelasztikus konstitúciós egyenlet okozza.

(a)

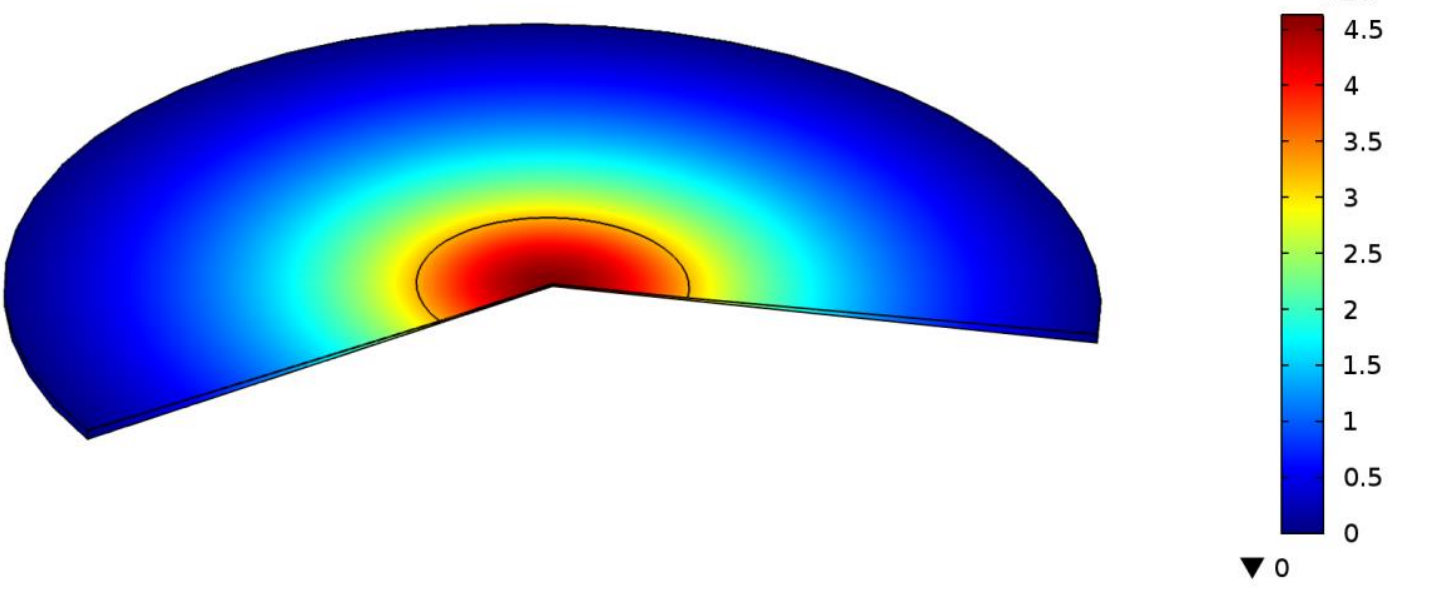


(b)

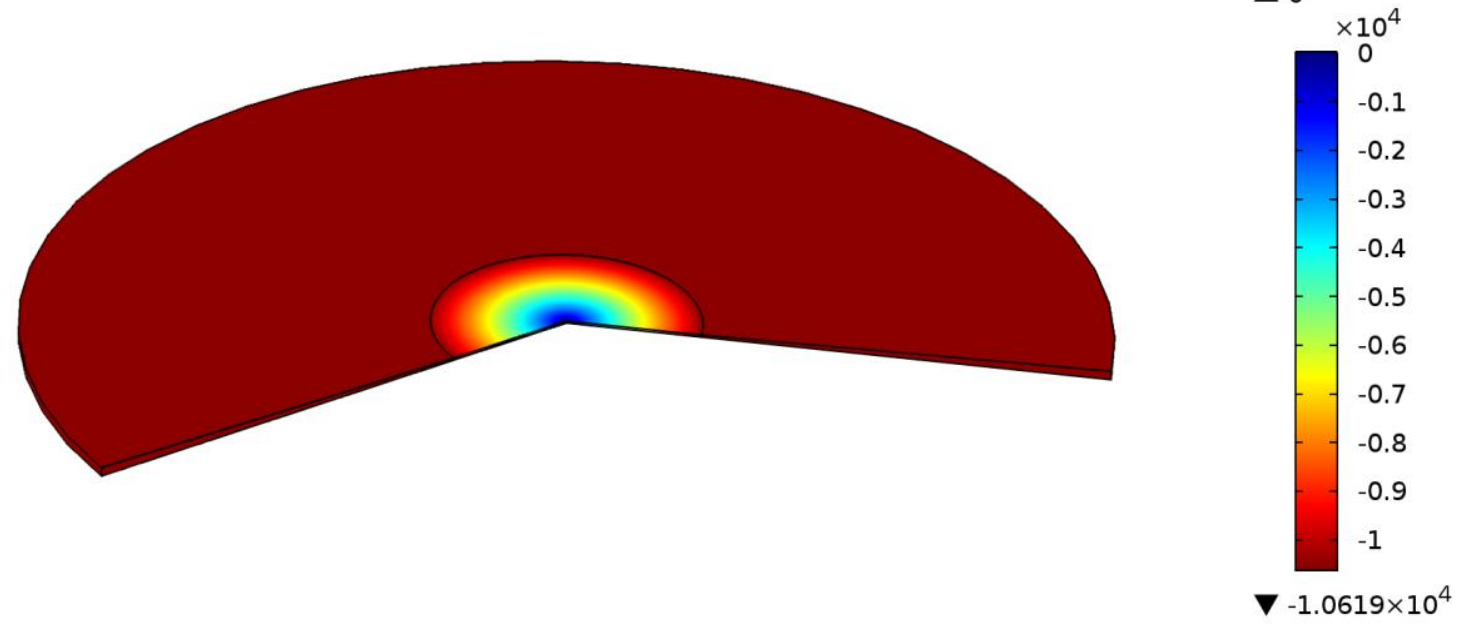

44. ábra: A CP25 geometria szimulációjának eredményei: (a) a nyomás [Pa], (b) a $\sigma_{\varphi z}$ nyírófeszültség [Pa] színkódolt függvénye, a 30 1/s előírt nyírási sebességnek megfelelő értéknél

A CP25 mérőgeometria szimulált reometriája szempontjából a két legfontosabb kiszámítandó mennyiség a forgó részre ható forgatónyomaték valamint a forgástengely irányában kialakuló nyomóerő.

A forgatónyomaték segítségével ki tudjuk számolni, hogy mekkora viszkozitást mérne a reométer, ez tehát a végeselemes modell pontosságának egyik alapvető tesztje. A forgatónyomatékot a feszültségtenzor komponenseiből az alábbi integrállal kell kiszámítani:

$$
M=2 \pi \int_{0}^{R}\left[\sigma_{\varphi r} n_{r}+\sigma_{\varphi z} n_{z}\right] r^{2} d r
$$

itt $\left(n_{r}, 0, n_{z}\right)$ a kúpos felső lap normálvektora hengerkoordinátákban, $R$ a CP25 sugara. Ennek eredménye alapján ki tudjuk számítani, hogy a reométer mekkora viszkozitást mérne. Ezeknek a szimulált viszkozitási adatoknak a modell szerinti viszkozitással való összevetését mutatja a 6. táblázat. Látható, hogy a Comsol által számított viszkozitás jól visszaadja a CC10 geometriával mért pontos viszkozitási értékeket, amiken a modell konstitúciós egyenlete alapszik, viszont ezektől észrevehetően eltér a CP25 geometriával mért viszkozitás, utóbbi erősen korlátozott mérési pontossága miatt. A CP25 geometriával végzett mérések ezzel a szilikonolajjal legfeljebb 15 1/s nyírási sebesség értékig tekinthetők értékelhetőnek, de ilyenkor is közel 10\%-os korrekciót kell alkalmazni. 


\begin{tabular}{|c|c|c|c|}
\hline $\begin{array}{c}\text { nyírási } \\
\text { sebesség } \\
{[1 / \mathrm{s}]}\end{array}$ & $\begin{array}{c}\text { Comsol } \\
\text { szoftverrel } \\
\text { szimulált viskozitás } \\
{[\mathrm{Pa} \text { s }]}\end{array}$ & $\begin{array}{c}\text { CC10 } \\
\text { geometriával } \\
\text { mért viszkozitás } \\
{[\mathrm{Pa} \text { s }]}\end{array}$ & $\begin{array}{c}\text { CP25 } \\
\text { geometriával } \\
\text { mért viszkozitás } \\
{[\mathrm{Pa} \text { s] }}\end{array}$ \\
\hline 0 & - & 520 & 578 \\
\hline 6 & 447 & 455 & 517 \\
\hline 12 & 406 & 415 & 466 \\
\hline 18 & 395 & 395 & 388 \\
\hline 24 & 376 & 376 & 291 \\
\hline 30 & 357 & 358 & 227 \\
\hline
\end{tabular}

6. táblázat: Szimulációval számított viszkozitási értékek összehasonlítása CC10 illetve a CP25 geometriával mért értékekkel, a nyírási sebesség függvényében

A forgástengely irányában kialakuló nyomóerőt a teljes (tehát a nyomást is tartalmazó) feszültségtenzor megfelelő komponenseinek a kúpos felső lapra való integrálásával kell kiszámítani, az alábbi képlet szerint:

$$
F_{\mathrm{t}}=2 \pi \int_{0}^{R}\left[\sigma_{z r} n_{r}+\left(\sigma_{z z}+p\right) n_{z}\right] r d r
$$

itt $\left(n_{r}, 0, n_{z}\right)$ a kúpos felső lap normálvektora hengerkoordinátákban, $R$ a CP25 sugara. A 7. táblázatban hasonlítjuk össze a szimulációval kapott és a CP25-tel mért értékeket.

\begin{tabular}{|c|c|c|}
\hline $\begin{array}{c}\text { nyírási } \\
\text { sebesség } \\
{[1 / \mathrm{s}]}\end{array}$ & $\begin{array}{c}\text { Comsol } \\
\text { szoftverrel } \\
\text { szimulált } \\
\text { nyomóerő }[\mathrm{N}]\end{array}$ & $\begin{array}{c}\text { CP25 } \\
\text { geometriával mért } \\
\text { nyomóerő } \\
{[\mathrm{N}]}\end{array}$ \\
\hline 3 & 0,103 & 0,109 \\
\hline 6 & 0,35 & 0,303 \\
\hline 9 & 0,72 & 0,5 \\
\hline 12 & 1,18 & 1,01 \\
\hline 15 & 1,75 & 1,21 \\
\hline
\end{tabular}

7. táblázat: A forgástengely irányában kialakuló viszkoelasztikus nyomóerő (normal force) Comsol szimulációval számított értékeinek összehasonlítása a CP25 geometriával mért értékekkel, a nyírási sebesség függvényében 
A kiszámított és a megmért értékek összevetésekor figyelembe kell vennünk azt a tényt is, hogy ennek a szilikonolajnak a CP geometriával való mérése meglehetősen pontatlan, és ez a nyírási sebesség növekedésével csak fokozódik, mint azt a 6 . táblázat egyértelműen mutatja. Ezen túlmenően, a normal force mérése rotációs reométerekkel általában is a nehéz, sokféle hibára érzékeny mérések közé tartozik. Fentieket figyelembe véve, a 7. táblázat által mutatott számértékek alapján az 5.14-19 egyenletekkel adott térfüggő konstitúciós egyenlet jól modellezi ezt a bonyolult nemlineáris viszkoelasztikus effektust.

\subsubsection{A CC méröfej végeselemes szimulációja}

A koncentrikus henger (CC) geometria végeselemes modellezésével a fô célom a szilikonolaj és a levegő közötti határfelület deformációjának, azaz a Weissenbergeffektusnak a szimulációja, továbbá annak kiszámítása, hogy ez mennyire befolyásolja a rotációs reométerrel végrehajtott mérések pontosságát. A $10 \mathrm{~mm}$ átmérőjü mérőfejjel rendelkező CC10 geometria Comsolban megalkotott modelljét a 45. ábrán mutatom be. A 45.(a) ábrán szürke színnel a pohár és a mérőfej látható, amint utóbbi már belemerült a kék színnel jelölt folyadékba. Mivel a pohár és a mérőfej csak a peremfeltételeket biztosítja a térfüggő konstitúciós egyenletekkel kiegészített áramlástani modellhez, ezért konkrétan csak a 45.(b) ábrán látható térfogatban van szükség a végeselemes szimuláció végrehajtására. Ezen az ábrán kék színnel a szilikonolajat, türkiz színnel pedig a felette elhelyezkedő levegő egy alkalmasan megválasztott részét jelöltem. Mivel most is az azimutális szögtől független folyamatot modellezünk, ezért az 45.(c) ábrán látható kétdimenziós geometriát használhatjuk, ha az egyenleteket hengerkoordinátákban írjuk fel. 
(a)

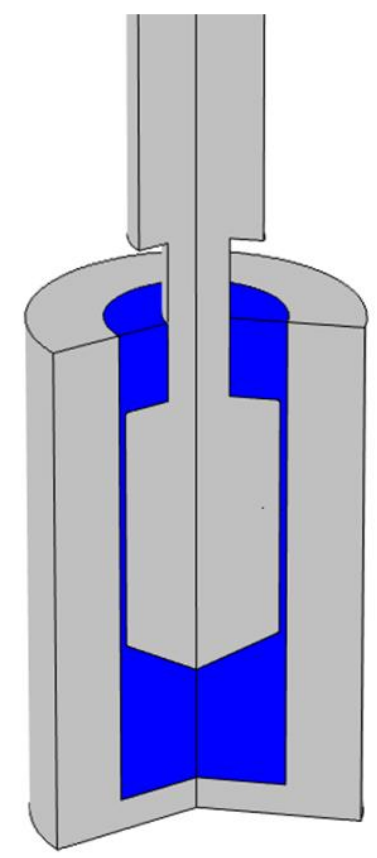

(b)

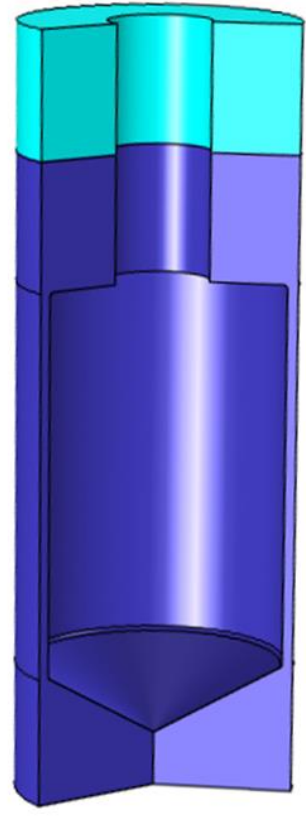

(c)

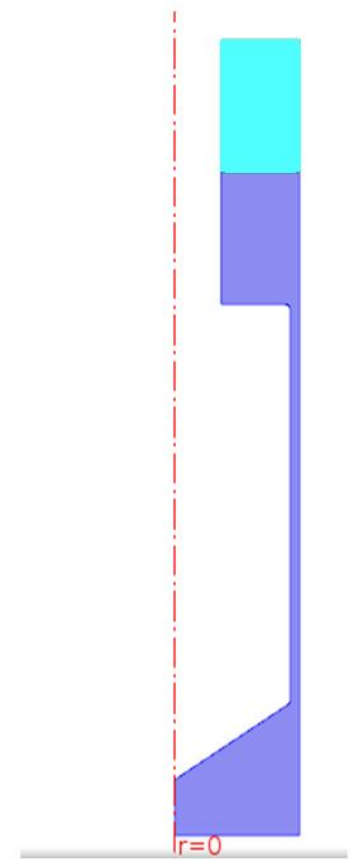

45. ábra: A koncentrikus henger (CC) geometria Comsolban megalkotott modellje

A szilikonolaj és a levegő közötti határfelület deformációjának nyomon követésére az úgynevezett level-set (továbbiakban LS) módszert használtam, ami a Comsol szoftverben implementálva van, általában csak a paraméterek finomhangolására van szükség. Az LS módszer lényege, hogy a két, nem keveredő folyadék (esetünkben az egyik a szilikonolaj, a másik a levegő) között egy olyan LS-függvénnyel tesz különbséget, amelynek értéke definíció szerint 1 az egyik folyadék által kitöltött térrészben és 0 a másik folyadék által kitöltött térrészben. A két érték között egy éles, de folytonosan differenciálható átmeneti tartomány jelenti a két folyadékot elválasztó határfelület helyét, amelyet a továbbiakban a 0,5 függvényértékhez tartozó kontúrvonallal jelölünk majd. A helytől és időtől függő $\Phi$ LS-függvény dinamikáját az alábbi egyenlet írja elő:

$$
\frac{\partial \Phi}{\partial t}+(\underline{\mathrm{v}} \cdot \nabla) \Phi=\gamma \nabla \cdot\left(\varepsilon \nabla \Phi-\Phi(1-\Phi) \frac{\nabla \Phi}{|\nabla \Phi|}\right),
$$

ahol $\underline{\mathrm{v}}$ a sebességmező, $\varepsilon$ és $\gamma$ pedig a stabil szimulációhoz a felhasználó által beállítandó numerikus skalár paraméterek.

Az áramlási tér peremfeltételeit a 46.(a) ábra segítségével ismertetem. A pirossal jelölt peremfelületek a mérés során a beállított nyírási sebességnek megfelelő szögsebességgel forognak a forgástengely körül, ennek megfelelően van elöírva a sebességmező azimutális komponense, a másik két sebességkomponens zéró. A 
narancssárga színnel jelölt alsó perem a mérőpohár alsó lapja, itt a sebességmező minden komponense zéró. A kék színü peremfelület a mérőpohár oldala, itt a függőleges sebességkomponens nincs elöírva, hogy az olaj szabadon tudjon kúszni a szabad felület alakváltozásával összhangban, a másik két sebességkomponens zéró. A zöld színü függőleges felület a forgó mérőfej tengelye, amely kezdetben a türkiz színű vízszintes peremig merül a szilikonolajba. A tengelyen az azimutális sebességkomponens a forgásnak megfelelö, a sugárirányú zéró, a függőleges sebességkomponens pedig itt sincs előírva, hogy az olaj szabadon tudjon kúszni a szabad felület alakváltozásával összhangban. A szilikonolaj-levegő határfelületen a sebességkomponensek folytonosan mennek át, a fekete színű perem pedig a levegő szabad felülete, itt a függőleges sebesség komponens zéró.

(a)

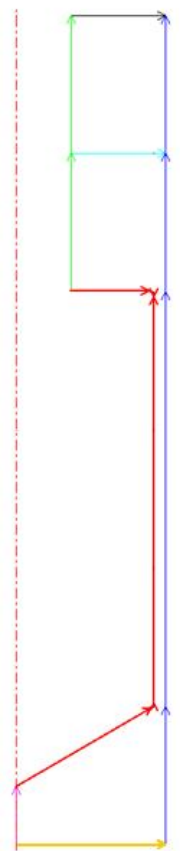

(b)

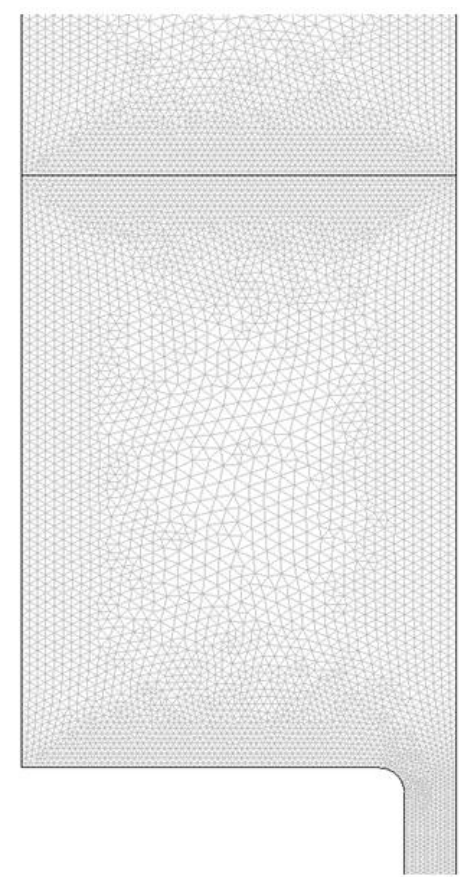

(c)

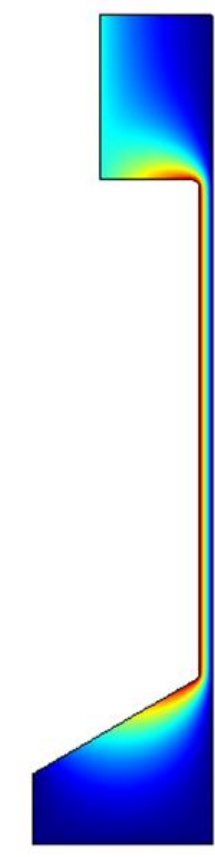

46. ábra: A sebességtér peremfeltételei CC geometria tengelymetszeti ábráján. Az azonos színnel jelölt peremeken, amik a valóságban forgásszimmetrikus felületek (a forgástengely kivételével), azonos peremfeltételek érvényesek

A végeselemes háló háromszög elemekkel készült, a geometria kritikus részein illetve a szilikonolaj-levegő határfelület közelében nagyon finom részletfeloldással, mint azt a 46.(b) ábrán szemléltetem.

A 46.(c) ábra a referenciaként használt tisztán viszkózus pszeudoplasztikus folyadékkal (azaz viszkoelasztikus jellegétől megfosztott, de minden egyéb tekintetben a szilikonolajjal megegyező modell-folyadékkal) készített szimuláció azimutális sebességét mutatja a hely függvényében. Az ezzel az esettel számítható forgatónyomaték értékek a 47. 
ábrán láthatóak, ezekhez viszonyítom majd a viszkoelasztikus modell egyenletekkel kapott megoldás esetében számítható forgatónyomatékot.
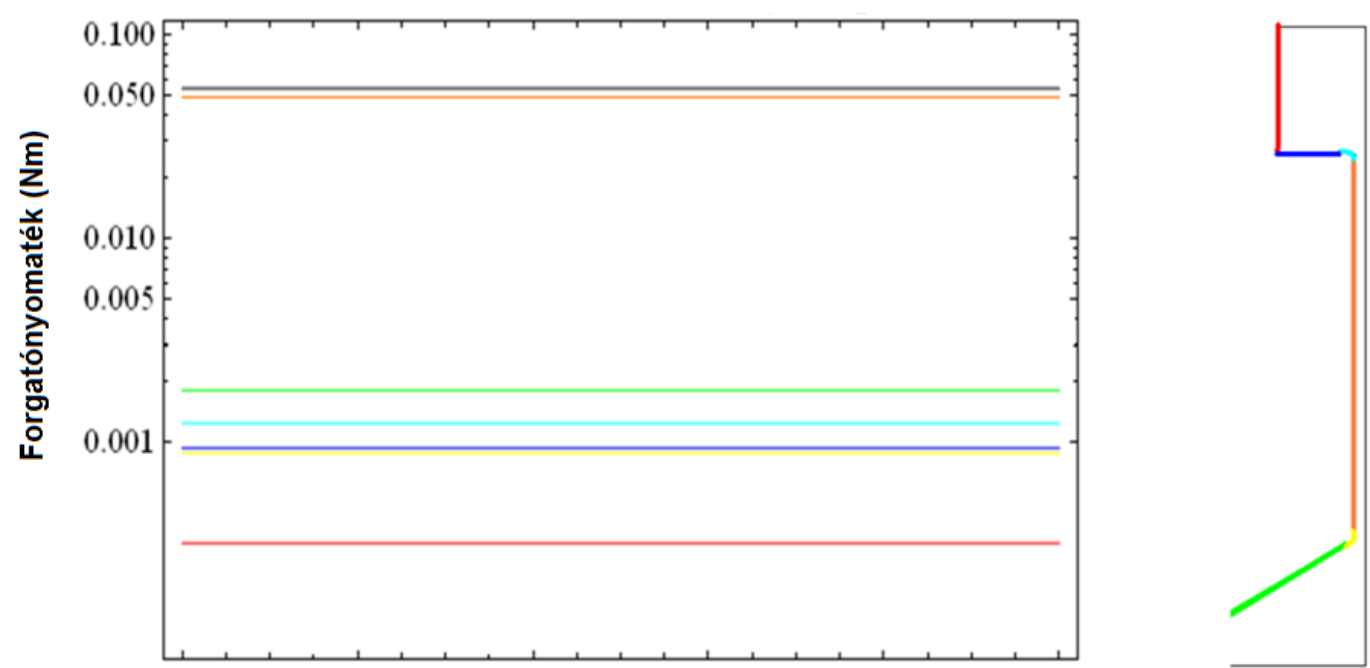

47. ábra: A CC10 geometria tisztán viszkózus modell-folyadékkal készített szimulációja esetén a mérőfej adott színnel jelölt felületein számítható forgatónyomaték értékek logaritmikus skálán. Fekete színnel az eredő teljes forgatónyomatékot jelöltük.

Az 5.14-19 egyenletekkel megadott térfüggő White-Metzner-modellel elvégzett szimuláció során, a 48. ábrán látható módon, időben lineárisan felfutó forgási szögsebességgel paramétereztem a nyírási sebességet: a mérőfej forgásának $3 \mathrm{rad} / \mathrm{s}$ értéke közel 36 1/s nyírási sebességet jelent. A lineáris felfutás a szimuláció stabilitása miatt is szükséges.

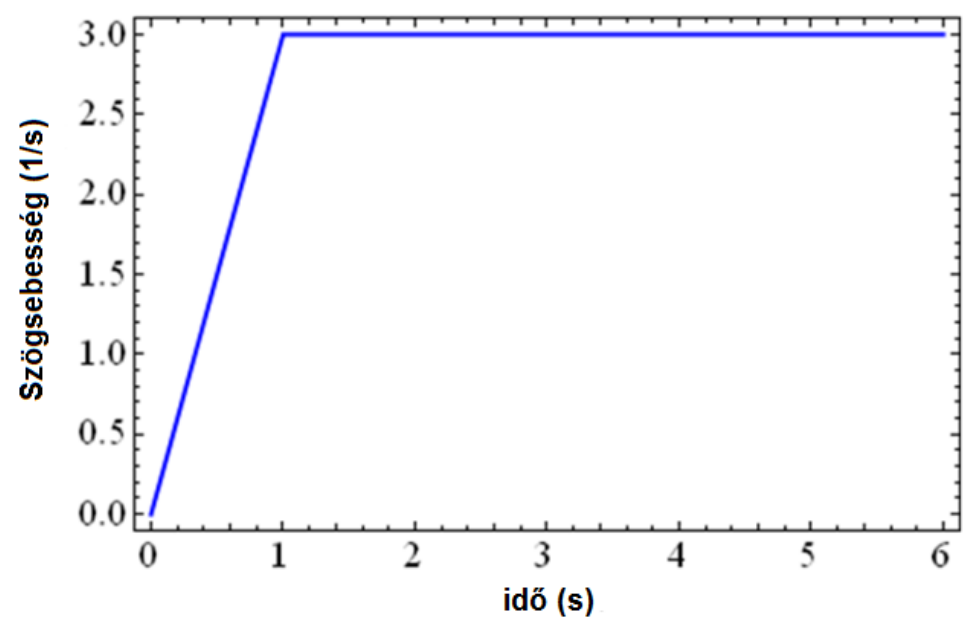

48. ábra: A viszkoelasztikus esetben elvégzett szimuláció során a mérőfej forgásának szögsebessége az idő függvényében. A $3 \mathrm{rad} / \mathrm{s}$ stacionárius érték 36 1/s nyírási sebességet jelent.

A szimuláció eredményeit az 49. és 50. ábrákon mutatom be. A 49.(a) ábra az áramlási képet és a szilikonolaj deformált, a mérőfej tengelye mentén megemelkedett 
felszínének kontúrját mutatja, utóbbi az $L S$-függvény 0,5 értékének kontúrvonala. A színkód az azimutális sebességkomponens értékét jelöli, a fehér nyilak pedig az sebességtér $r z$ síkbeli vetületének vektormezőjét reprezentálják. A 49.(b) ábrán az (a) ábra legfontosabb részét látjuk kinagyítva, a (c) ábra pedig ugyanebben a nagyított nézetben a nyomást mutatja.

(a)

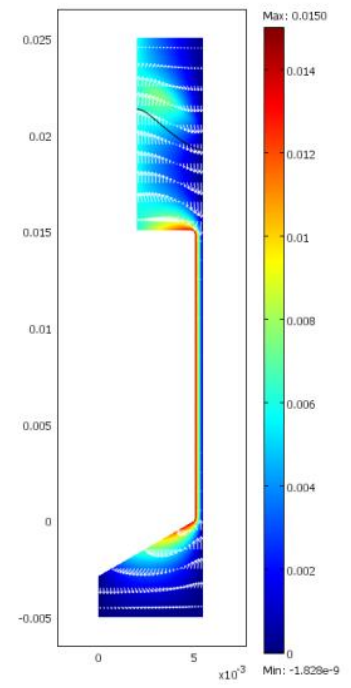

(b)

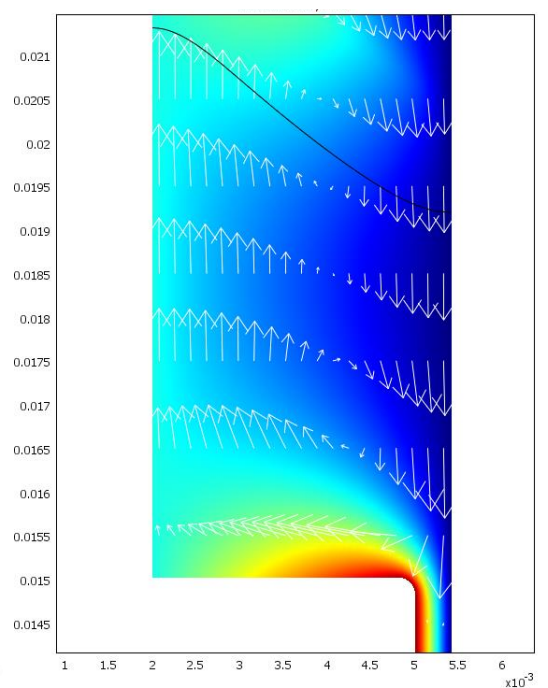

(c)

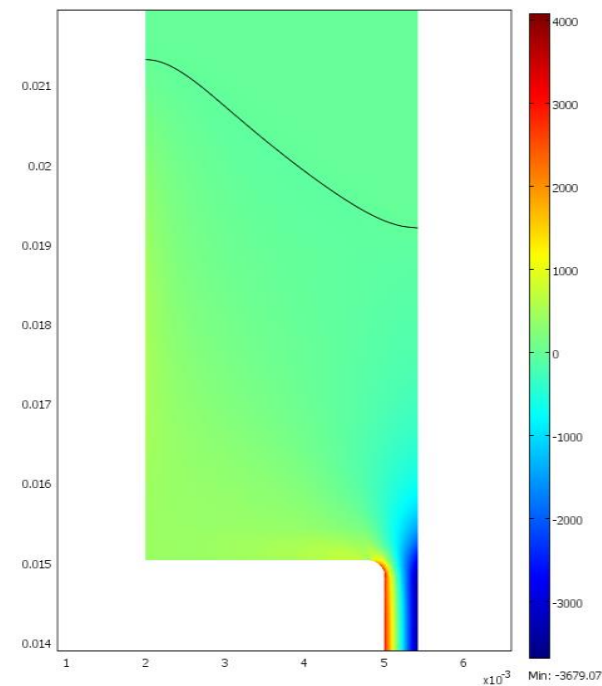

49. ábra: CC10 mérőgeometria esetén a nemlineáris viszkoelasztikus szilikonolajban kialakuló sebességmező (a, b) és nyomás (c), 36 1/s nyírási sebesség esetén.

A 50. ábra a nemlineáris viszkoelasztikus feszültségtenzor $r z$ és $z z$ komponensének helyfüggését mutatja. Az 5.21 formula szerint a nyomás mellett ezek adnak járulékot ahhoz a függőleges irányú erőhatáshoz, ami a szilikonolaj felszínét deformálja, azaz a Weissenberg-effektushoz. A szilikonolaj felszínének kontúrját összehasonlítva a Weissenberg-effektusról készített fényképpel, ami az 51. ábrán látható, kijelenthetjük, hogy a nemlineáris viszkoelasztikus White-Metzner-modellt alkalmazó végeselemes szimuláció jól reprodukálja a szilikonolaj-levegő határfelületnek a mérés közben megfigyelthez hasonló alakváltozását. 
(a)

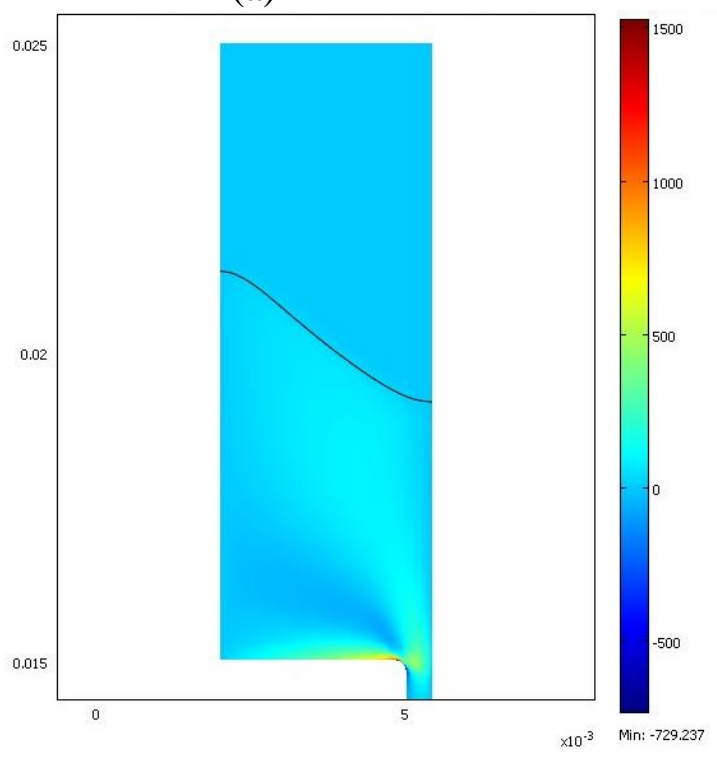

(b)

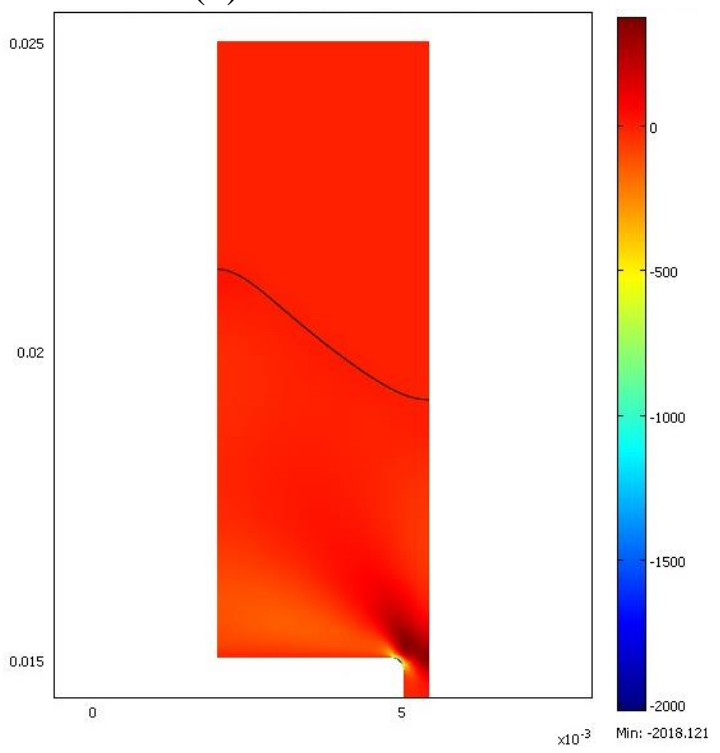

50. ábra: CC10 mérőgeometria esetén a nemlineáris viszkoelasztikus szilikonolajban kialakuló viszkoelasztikus feszültségtenzor rz (a) és zz (b) komponense, 36 1/s nyírási sebesség esetén.

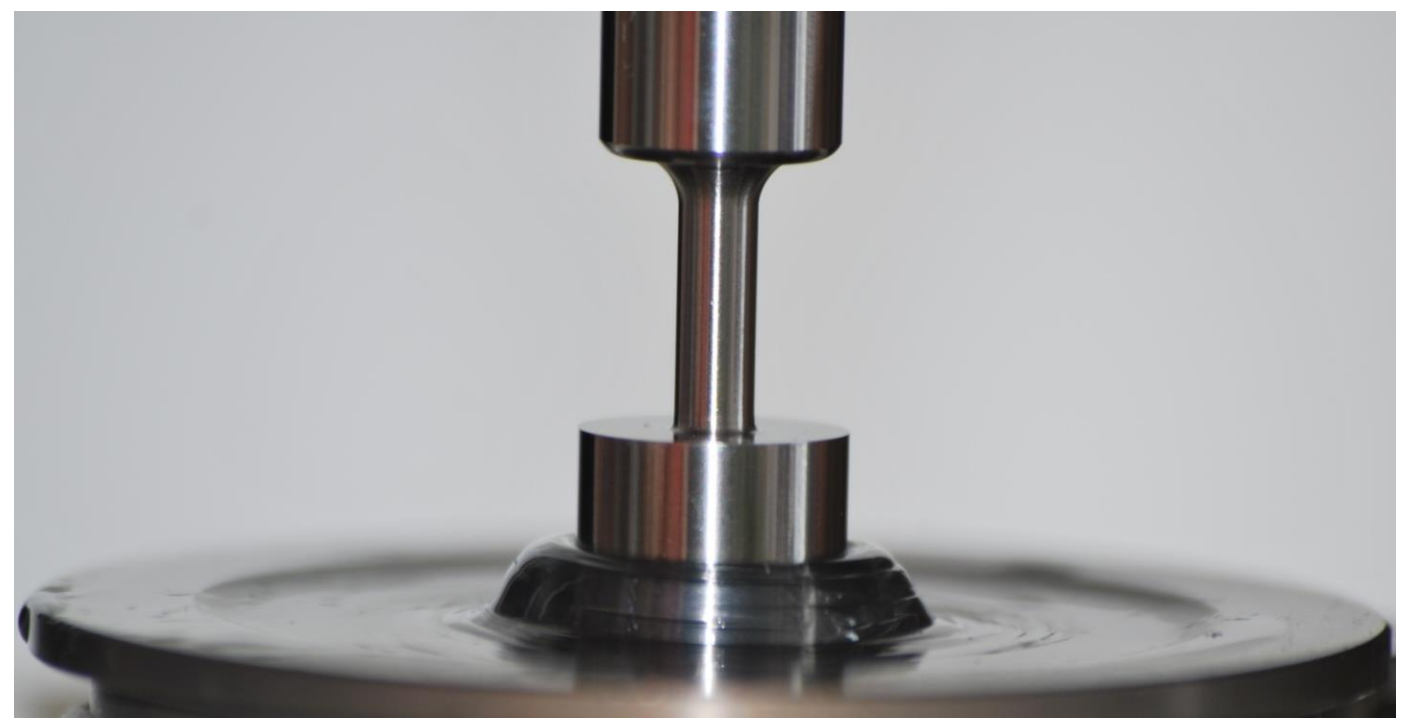

51. ábra: CC10 mérőfej forog az AK1.000.000 típusú szilikonolajban, jól látható a Weissenbergeffektus által deformált folyadékfelszín, amint felemelkedik a mérőfej forgó felszínén. A fénykép nem a CC10 valódi mérési helyzetében készült, az effektus jobb fényképezhetősége érdekében.

A Weissenberg-effektusnak a CC10 geometriával történő méréseket befolyásoló hatásának kiszámításához a szilikonolaj által a forgó mérőfejre kifejtett forgatónyomaték meghatározása szükséges, amit ebben az esetben is az 5.20 formulával kell elvégezni. A szimuláció alapján kapott eredményeket a 47. ábrán bemutatott tisztán viszkózus modellfolyadék esetére mint referenciára normálva mutatjuk be a 52. ábrán: a fontos felületrészeken kiszámított, valamint az eredő teljes normált forgatónyomaték értékeket az idő függvényében a stacionárius helyzetig ábrázoljuk. 

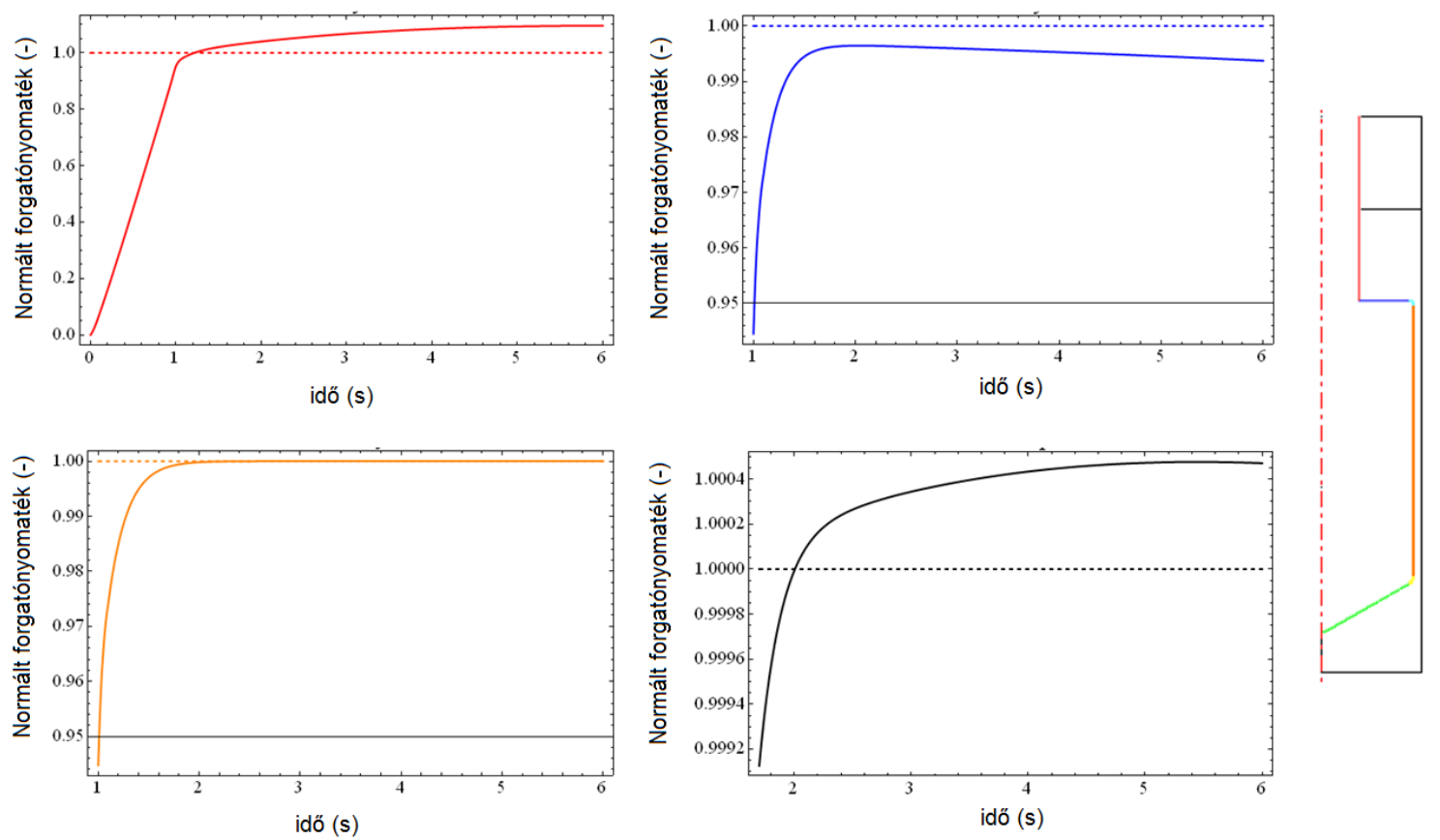

52. ábra: A CC10 mérőfej narancssárga, kék és piros színnel jelölt felületein kiszámított forgatónyomaték értékek az idő függvényében a megfelelő színekkel ábrázolva, a szilikonolaj viszkoelasztikus modellje alapján, a tisztán viszkózus modell-folyadékra esetére normálva. A fekete színü görbe a szilikonolajba merülő teljes felületre számított eredő forgatónyomaték, szintén a modell-folyadék esetére normálva.

Látható, hogy a narancssárgával jelölt fő mérőfelületen nem változik a forgatónyomaték értéke a tisztán viszkózus modell-folyadékhoz képest, de a pirossal jelölt tengely felületen természetesen növekszik a forgatónyomaték, hiszen erre kúszik fel a szilikonolaj. Az áramlás azonban úgy változik meg a Weissenberg-effektus hatására, hogy a kékkel jelölt vízszintes felületen csökken a forgatónyomaték. Ez a csökkenés, valamint a többi felületen történő kisebb változások lényegében kompenzálják a tengelyen kialakuló növekedést. A fekete színnel ábrázolt eredő forgatónyomaték csak elhanyagolható mértékben növekszik meg a Weissenberg effektus hatására, tehát a Weissenberg-effektus érdemben nem befolyásolja a szilikonolaj dinamikai viszkozitás mérésének pontosságát CC10 geometria esetén. 


\section{6 Összefoglalás}

Jelen PhD értekezés egy nagy viszkozitású szilikonolaj (poli-dimetil-sziloxán, PDMS) reológiai tulajdonságainak részletes kísérleti vizsgálatát, és a mérési eredményekre alapozott modellezését mutatja be. A vizsgált anyag nemlineáris viszkoelasztikus folyadék, az ilyen folyadékok viszkózus tulajdonságuk mellett rugalmas viselkedéssel is bírnak. Az erre a célra mintaként kiválasztott konkrét anyag jól reprezentálja ezt a fontos anyagcsaládot.

A szilikonolajokat igen széles körben alkalmazzák az alap- és alkalmazott kutatástól kezdve egészen a szerteágazó ipari felhasználásokig. Különleges reológiai viselkedésük miatt gyakran használják a polimerkémiában és az anyagtudományokban. Tesztfolyadékként előszeretettel alkalmazzák új reológiai elméletek, újszerű mérési eljárások és mérőműszerek hitelesítésére. A jármüipar elsősorban a rezgések és lengések kontrollált csillapítására használja a szilikonolajokat.

\section{Alkalmazott módszerek}

A rotációs és oszcillációs méréseket egy Anton Paar Physica MCR 101 típusú reométerrel végeztük. Ez egy modern, számítógép-vezérelt müszer, amely már légcsapágyat tartalmaz, így a mérőtest forgásakor fellépő súrlódási veszteség igen kicsi, ezáltal lehetővé teszi a pontos mérést a rotációs és oszcillációs vizsgálatok során. A reométer mérési frekvenciáját a $0.01-100 \mathrm{~Hz}$ tartományban, míg a hőmérsékletet 0 és $120^{\circ} \mathrm{C}$ fok között tudjuk változtatni. A szilikonolaj nemlineáris viszkoelasztikus tulajdonágainak leírásához szükséges LAOS teszteket a legújabb Anton Paar Physica, MCR 702-es reométeren végeztük el. A szoftverből mind a bemenő időfüggő nyírás, kimenő időfüggő nyírófeszültség jel, mind az FT reológiai, mind az Ewoldt paraméterek hozzáférhetőek.

A reométeres méréseinkhez legtöbbször a $10 \mathrm{~mm}$ belső-henger átméröjü koncentrikus henger (CC10) geometria, illetve bizonyos estekben a 25mm átmérőjü kúp-lap (CP25) geometria bizonyult optimálisnak, ezért ezeket használtuk.

Egy Göttfert Rheograph 25 típusú kapilláris reométerrel méréseket végeztünk az anyag nagy nyírási sebességhez $\left(10^{5} \quad 1 / \mathrm{s}\right)$ tartozó viszkózus tulajdonságainak meghatározására. Ez a müszer egyszerre két különböző kapillárison nyomja át a mérendő folyadékot, ezzel is jelentősen pontosítva a mérést. 
A Diffusing Wave Spectroscopy egy mára már kiforrottnak tekinthető módszer a folyadékok nagyfrekvenciás reológiai tulajdonságainak vizsgálatára. Ez a módszer a passzív mikroreológiai eljárások körébe tartozik, amely a mintán szóródó fény fluktuációiból tud a minta lineáris viszkoelasztikus jellemzőire következtetni. Az átlátszó anyagoknál, mint pl. a PDMS, a fény szóródását mesterségesen kell előidézni, jellemző módon nyomjelző részecskéket kell eloszlatni a mintában. A szilikonolaj fényszórásos vizsgálatához titán-dioxid nyomjelző részecskék bizonyultak a legmegfelelőbbnek. A nagy viszkozitású szilikonolajat DWS ReserchLab (LS Instruments) készülékkel vizsgáltuk transzmissziós módban.

A mérésekre illesztett, és később számos megfontolás alapján meghatározott konstitutív egyenletek megoldását többfajta szimulációs környezetben valósítottuk meg. A koncentrált paraméterü (azaz térváltozótól független) modelleket tartalmazó szimulációkat a Wolfram Mathematica és a Matlab programok segítségével oldottuk meg. A koncentrált paraméterü konstitúciós egyenlet általánosításával kapott térfüggő parciális differenciálegyenlet-rendszert tartalmazó modellek megoldásához bonyolultságuk miatt numerikus módszerre volt szükség. A végeselemes módszerek (FEM) jól alkalmazhatók ilyen célra, ezért a Comsol szoftvert használtam.

\section{Eredmények}

1. Rotációs reométerrel megmértem egy reprezentáns nagy viszkozitású szilikonolaj (Wacker AK1.000.000) viszkoelasztikus tulajdonságait a frekvencia és a hőmérséklet függvényében. Kapilláris viszkoziméterrel kiegészítő méréseket végeztem a szilikonolaj dinamikai viszkozitására vonatkozóan a reométerrel elérhetőnél lényegesen nagyobb nyírási sebesség tartományban is. A mérési adatok analízisével megállapítottam, hogy a szilikonolaj nemlineáris viszkoelasztikus folyadék, a viszkozitásának a nyírási sebességtől való függése pszeudoplasztikus (shear-thinning) viselkedést mutat, teljesíti az ún. CoxMerz szabályt, továbbá rendelkezik az ún. TTS (time-temperature superposition) tulajdonsággal. Kis amplitúdójú oszcillációs nyírási (SAOS) méréseimre alapozva meghatároztam az előbbi tulajdonságokat jellemző anyagi paramétereket.

A méréseimre alapozva kidolgoztam egy állandó súlyozású, ötelemű, WhiteMetzner típusú koncentrált paraméteres konstitúciós (anyagi) egyenletet, amely jól leírja az 1. pontban ismertetett nemlineáris viszkoelasztikus tulajdonságok mindegyikét. Ebben a modellben a viszkozitásnak a nyírási sebességtől való függését a Cox-Merz szabály 
segítségével definiáltam, az egyes elemek közötti súlyozást pedig a lineáris tartományban érvényes arányok szerinti választottam meg.

[T1, T2, T3]

2. A nagyfrekvenciás tartományban egy újfajta, ún. Diffusing Wave Spectrosopy (DWS) módszerrel mért veszteségi és tárolási modulusz adatok vizsgálata alapján megállapítottam, hogy a $20-70{ }^{\circ} \mathrm{C}$ hőmérsékleti tartományban a DWS módszerrel kapott eredmények jól illeszkednek a SAOS mérések eredményeihez, különösen a magasabb hőmérsékleti értékek esetén. Megállapítottam továbbá, hogy $10^{8} \mathrm{rad} / \mathrm{s}$ körfrekvenciáig nincs második keresztezési pontja a veszteségi és tárolási modulusz görbéknek, amelyek a teljes nagyfrekvenciás tartományban sima frekvenciafüggésủek és dominánsan elasztikus viselkedést mutatnak.

Kimutattam, hogy a szilikonolaj a reométerrel mérhető, tipikusan $0.01-100 \mathrm{~Hz}$ tartománynál lényegesen szélesebb frekvencia tartományban, legalább $16 \mathrm{kHz}$ értékig eleget tesz a Cox-Merz szabálynak.

Megállapítottam, hogy a nagyfrekvenciás tartományban a domináns moduluszok továbbra is eleget tesznek a TTS szabálynak, erre alapozva meghatároztam azt a $60{ }^{\circ} \mathrm{C}$-ra érvényes mestergörbét, mely a két müszerrel mért, közel hat dekádot átfogó frekvencia tartományra érvényes. Ezt a mestergörbét egy hatelemü Maxwell-modellel illesztettem, amely pontosan modellezi a szilikonolaj lineáris viszkoelasztikus tulajdonságait.

3. A szilikonolajon végzett nagy amplitúdójú oszcillációs nyírási (LAOS) tesztek mérési eredményeinek elemzése során megállapítottam, hogy a nemlineáris viszkoelasztikus viselkedés tipikusan a 100\% nyírási amplitúdó felett kezd jelentőssé válni, továbbá nagyobb oszcillációs körfrekvenciák esetén mindig erősebb a nemlinearitás.

A viszkózus illetve elasztikus nyírófeszültségre vonatkozó Lissajous-Bodwitch görbék elemzésével megállapítottam, hogy a szilikonolaj a nemlineáris tartományban viszkózus szempontból ún. ciklikusan pszeudoplasztikus (intracycle shear thinning), elasztikus szempontból pedig ún. ciklikusan nyírásra keményedő (intracycle strain thickening) anyagként viselkedik. A folyamatok elemzése során kimutattam, hogy a viszkózus nyírófeszültség jelben megjelenő másodlagos hurkok (secondary loop) a 
reométer vezérlőrendszere által létrehozott nyírási sebesség jel nem tisztán szinuszos jellegének a következményei.

A DWS és SAOS mérésekre alapozva kidolgoztam egy módosított, hatelemü, változó súlyozású, White-Metzner típusú koncentrált paraméteres konstitúciós egyenletet. Szemben az 1. tézispontban ismertetett állandó súlyozású ötelemü White-Metznermodellel, ez a konstitutív egyenlet az amplitúdó-pásztázó illetve a LAOS mérések eredményeit is kiválóan modellezi. A szimulált eredmények mind a mért nyers nyírófeszültségre, mind a belőlük számolt elasztikus és viszkózus Lissajous-Bodwitch görbékre tökéletesen illeszkednek.

A szimulációk segítségével kiegészített mérési eredmények alapján, az ún. Pipkin diagramok segítségével összehasonlítottam kétféle, a nemlineáris tulajdonságokat jellemző mennyiséget, mind az elasztikus, mind a viszkózus viselkedésre vonatkozóan. Megállapítottam, hogy a nemlineáris viselkedés döntő mértékben megnöveli a magasabb felharmonikus komponensek súlyát a nyírófeszültségben. Az általam végzett szimulációk előrejelzése szerint a nemlineáris viszkózus jellegben egy lokális maximum figyelhető meg $50 \mathrm{rad} / \mathrm{s}$ körfrekvencia értéknél, a nemlineáris elasztikus jelleg pedig $30 \mathrm{rad} / \mathrm{s}$ érték fölött lényegében függetlenné válik a körfrekvenciától.

$[\mathrm{T} 3, \mathrm{~T} 4]$

4. A koncentrált paraméteres, változó súlyozású White-Metzner-modellt térkoordinátáktól függő konstitúciós egyenletté általánosítottam, melyben a nyírófeszültség-mező nagy deformációkra is érvényes ún. upper-convected deriváltja helyettesíti a koncentrált paraméterü modell egyszerü időderiváltját. Ezzel a térfüggő konstitúciós egyenlettel két reometriai mérést modelleztem végeselemes szimulációval.

A kúp-lap (CP) geometriájú mérés végeselemes modellezésével kiszámítottam a szilikonolaj által a mérő geometriára a forgástengely irányában ható erőt a nyírási sebesség függvényében. Ez az erő a nyírásra merőleges irányban fellépő feszültségtenzor komponensek következménye, ez okozza a Weissenberg-effektust is. Összevetve a kiszámított és a megmért értékeket megállapítottam, hogy a térfüggő konstitúciós egyenlet jól modellezi ezt a bonyolult nemlineáris viszkoelasztikus effektust. 
A koncentrikus henger (CC) geometriájú mérés szimulációja esetében a $\mathrm{CP}$ geometriához használt végeselemes modellt továbbfejlesztettem úgy, hogy képes legyen leírni a szilikonolaj-levegő határfelület időbeli változásának dinamikáját is. A szimulációk reprodukálják a határfelületnek a mérés közben megfigyelthez hasonló alakváltozását. Az eredmények elemzésével megmutattam, hogy a Weissenberg-effektus érdemben nem befolyásolja a dinamikai viszkozitás mérésének pontosságát CC10 geometria esetén.

[T3, T5] 


\section{Summary}

In this $\mathrm{PhD}$ thesis a detailed experimental investigation on the rheological properties of a high viscosity silicone oil and its modeling based on the measured data (polydimethylsiloxane, PDMS) are reported. The material studied is a nonlinear viscoelastic fluid, i.e., it displays both elastic and viscous behavior. The particular substance is a good representative of this important material class.

Silicone oils (polydimethylsiloxane, PDMS) have many application areas ranging from fundamental research and applied sciences to several branches of modern industry. In particular, PDMS is frequently used in polymer and materials science because of its peculiar rheological properties. PDMS is also a popular test material for new rheological theories and for elaborating novel measuring methods and devices. The automotive industry mainly uses the silicon oils for the controlled reduction of vibrations and oscillations.

\section{Materials and methods}

The rotational and oscillatory tests were performed with an Anton Paar Physica MCR 101 rheometer. This is a modern, computer-controlled device, which contains air bearing to reduce the friction of the rotating measuring head, thus allowing accurate measurements during the rotational and oscillatory tests. The frequency range of the rheometer is from $0.01 \mathrm{~Hz}$ to $100 \mathrm{~Hz} \mathrm{rad} / \mathrm{s}$, while the temperature range is from $0{ }^{\circ} \mathrm{C}$ to 120 ${ }^{\circ} \mathrm{C}$. To have a better insight into the nonlinear properties of the material we performed true LAOS (Large Amplitude Oscillatory Shear) test. The measurements were done with an Anton Paar MCR702 rheometer. This is the latest model of the company, with increased precision and twin motor setup. The software provides both the raw shear strain and shear stress data signal both the FT-rheological and Ewoldt parameters.

For these measurements, mostly the concentric cylinder measuring geometry was applied with $10 \mathrm{~mm}$ inner gap (CC10), and in certain cases, the cone and plate measuring geometry with $25 \mathrm{~mm}$ diameter (CP25) was also used.

A Göttfert Rheograph 25 capillary rheometer was the instrument to measure the viscosity of the silicon oil at high shear rates $\left(10^{5} 1 / \mathrm{s}\right)$. The device presses the material through two different capillaries at the same time, thus, the increase in the accuracy of the measurement was significant. 
Diffusing Wave Spectroscopy is a well-developed method to probe the viscoelastic properties of the silicone oil at higher frequencies. DWS is a passive microrheological technique, which probes the decorrelation of multiply scattered light due to the thermal motion of scattering objects in the sample. Since the silicone oil itself is transparent, titanium dioxide tracer particles were added to trigger the scattering. The silicone oil was characterized in transmission mode with a DWS ResearchLab (LS Instruments) device, which includes a software package to perform the microrheological calculations.

The developed constitutive equations, which were based to the measured data and later determined by many considerations, were solved in several computing environment. The simulations, which contained lumped parameter models, were carried out with the Wolfram Mathematica and the Matlab software. The space dependent partial differential equations, which are the generalization of the lumped parameter model, were solved by numerical methods because of their complexities. The finite element methods are useful for these problems, therefore, the Comsol software was used.

\section{New scientific results}

1. The viscoelastic properties of the representative high viscosity silicone oil (Wacker AK1.000.000) were measured at different frequencies and temperatures with the conventional rheometer. The viscosity of the material at much higher shear rates that can be obtained with a rotational rheometer were measured on a capillary rheometer. From the analysis of the measured data, it was found that the silicon oil was a nonlinear viscoelastic material having a shear-thinning behavior, and obeying the so-called Cox-Merz rule as well as the so-called TTS (Time Temperature Superposition). The parameters of the abovementioned properties were also determined.

Based on these measurements, a constant-weighed five-element White-Metzner type lumped parameter constitutive equation was developed, which described all the above-mentioned linear and nonlinear viscoelastic properties very well. The shear rate dependent viscosity was defined according to the Cox-Merz rule, and the weighing between the elements were done according to the rates which were valid in the linear regime.

[T1, T2, T3] 
2. On the basis of DWS (Diffusing Wave Spectroscopy) measurements, which expands the measured loss and storage moduli to the high frequency range, it was found that in a temperature range of $20-70{ }^{\circ} \mathrm{C}$, the DWS data fits well to the SAOS data in the overlapping frequency region, especially at the higher temperature end. From the analysis of the measured DWS data, it became clear that the elastic modulus stays dominant and increases with frequency without a second cross-over point up to $10^{8} \mathrm{rad} / \mathrm{s}$.

It was pointed out that the investigated silicon oil obeyed the Cox-Merz rule in a much broader frequency range than was found from measurements on the conventional rheometer up to $16 \mathrm{kHz}$, at least.

It was verified that TTS rule was still valid for the predominant modulus in the highfrequency range. A joined master curve was created from the data sets measured by SAOS and by DWS, and the selected $60^{\circ} \mathrm{C}$ being the reference temperature. This joined master curve is valid for almost six orders of magnitude frequency range. A six-element Maxwell model was fitted to the joined master curve, accurately describing the linear viscoelastic properties of the silicone oil.

3. During the analysis of the measured large amplitude oscillatory shear (LAOS) tests of the silicone oil, it was found that typically, the non-linear viscoelastic behavior became significant above $100 \%$ shear amplitude, and the higher the angular frequency and the shear amplitude of the oscillation were, the stronger the nonlinearity was.

From the plot of the shear stress on elastic and viscous Lissajous-Bodwitch curves, it was observed that the silicon oil in the nonlinear regime displayed intracycle strain stiffening and intracycle shear thinning behavior. During the analysis of these process, it was found that the secondary loops in the viscous stress curves occurred because the rheometer controlled input shear rate signal was not a pure sinusoidal any more.

On the basis of the DWS and SAOS data, a modified, six-element, varying weighed White-Metzner type lumped parameter constitutive equation was developed. Compared to the constant-weighed five-element White-Metzner model (described earlier), this constitutive equation could describe well even the results of the amplitude sweep and LAOS measurements. The simulated results fit very well both to the raw shear stress signal and the elastic and viscous Lissajous-Bodwitch curves. 
Based on the simulation complemented measured data, two nonlinear properties were compared with the help of Pipkin diagrams, both for the elastic and the viscous part. It was observed that the nonlinearity increases the weight of the higher harmonics in the shear stress signal decisively. Two particular phenomena were identified from the Pipkin diagrams. First, the viscous nonlinearity has a maximum around $\omega=50 \mathrm{rad} / \mathrm{s}$ angular frequency, thus, the material becomes more and more linear from the viscous side above and below this frequency. Second, above $\omega=30 \mathrm{rad} / \mathrm{s}$ angular frequency, the elastic nonlinearity becomes nearly independent from the angular frequency.

$[\mathrm{T} 3, \mathrm{~T} 4]$

4. The lumped parameter varying weighed White-Metzner model was generalized to a space-dependent constitutive equation, where the upper convected derivate, which is valid even for high shear stress field, substitutes the normal time derivate from the lumped parameter model. Two rheometry measurements were modeled with this space-dependent constitutive equation using finite element simulations.

The shear rate dependent normal force of the silicon oil was calculated using finite element simulations for the cone and plate (CP) measuring geometry. This force is due to the shear perpendicular to the shear stress tensor components causing the Weissenberg effect. A comparison of the measured and the calculated data revealed that the space-dependent constitutive equation described this complex nonlinear viscoelastic behavior well.

For the simulation of the concentric cylinder (CC) measuring geometry, the finite element model was developed, which was used to simulate the CP measuring geometry, therefore, it could describe the time-dependent dynamics of the silicon-air interface. The CC simulations reproduced the interface deformations observed during measurements. From the analysis of the simulation results, it was shown that the Weissenberg effect did not substantially affect the precision of the simple shear tests substantially for the CC10 measuring geometry. 


\section{Publikációk}

\section{A disszertáció alapjául szolgáló közlemények:}

[T1] Kőkuti Zoltán, Kokavecz János, Holczer István, Danyi Antal, Gábor Zoltán, Czirják Attila, Szabó Gábor, Ailer Piroska, Pézsa Nikolett, Németh Huba, Palkovics László: „,Torziós lengéscsillapítóban alkalmazott viszkózus folyadék modellezése”, A Jövő Jámüve, 2009/3-4 (2009) pp. 61-65

[T2] Z. Kőkuti, J. Kokavecz, A. Czirják, I. Holczer, A. Danyi, Z. Gábor, G. Szabó, N. Pézsa, P. Ailer, L. Palkovics:

„Nonlinear viscoelasticity and thixotropy of a silicone fluid”, In: Ferencz Árpád, Klebniczki József, Lipócziné Csabai Sarolta, Borsné Pető Judit, Fábián Csaba (szerk.) Proceedings of the 2nd International Scientific and Expert Conference: TEAM 2010 : AGTEDU 2010 (ISBN:978-963-7294-85-3): (2010) pp. 577-583.

[T3] Z. Kőkuti, K. van Gruijthuijsen, M. Jenei, G. Tóth-Molnár, A. Czirják, J. Kokavecz, P. Ailer, L. Palkovics, A.C. Völker, G. Szabó:

„High-frequency rheology of a high viscosity silicone oil using diffusing wave spectroscopy",

Applied Rheology 24:6 (2014) 63984 (7 pages). IF:1,078

[T4] Z. Kőkuti, L. Völker-Pop, M. Brandstätter, J. Kokavecz, P. Ailer, L. Palkovics, G. Szabó, A. Czirják:

„Exploring the nonlinear viscoelasticity of a high viscosity silicone oil with LAOS”, Applied Rheology, submitted, 2015

\section{Egyéb közlemények}

[1] Z. Kőkuti, J. Kokavecz, A. Czirják, I. Holczer, A. Danyi, Z. Gábor, G. Szabó, N. Pézsa, P. Ailer, H. Németh, L. Palkovics:

„Nonlinear viscoelasticity of silicone fluids", poster az „Annual European Rheology Conference 2010, Göteborg” konferencián

[2] Z. Kőkuti, J. Kokavecz, A. Czirják, I. Holczer, Cs. Vass, A. Danyi, Z. Gábor, G. Szabó, N. Pézsa, P. Ailer, H. Németh, L. Palkovics:

„Nonlinear viscoelasticity and thixotropy of silicone fluids", poster az „European Seminar on Coupled Problems 2010, Pilsen” konferencián 
[3] Z. Kőkuti, J. Kokavecz, A. Czirják, I. Holczer, A. Danyi, Z. Gábor, G. Szabó, N. Pézsa, P. Ailer, L. Palkovics:

„Nonlinear viscoelasticity and thixotropy of a silicone fluid”, előadás a „TEAM 2010 / AGTEDU 2010” konferencián, Kecskemét, 2010. november $4-5$.

[4] Z. Kőkuti, J. Kokavecz, A. Czirják, I. Holczer, A. Danyi, Z. Gábor, G. Szabó, N. Pézsa, P. Ailer, L. Palkovics:

„Nonlinear viscoelasticity and thixotropy of a silicone fluid”, A Jövő Jámüve, 2011/1-2, pp. 134-136

[5] Z. Kőkuti, J. Kokavecz, A. Czirják, I. Holczer, A. Danyi, Z. Gábor, G. Szabó, N. Pézsa, P. Ailer, L. Palkovics:

„Nonlinear viscoelasticity and thixotropy of a silicone fluid”, Annals Of Faculty Engineering Hunedoara - International Journal Of Engineering, 2011/2, pp. 177-180

[6] Z. Kőkuti, K. van Gruijthuijsen, M. Jenei, A. Czirják, J. Kokavecz, A. Danyi, P. Ailer, L. Palkovics, A. C. Völker, G. Szabó:

„High-frequency rheology of nonlinear silicone fluids", poster az "International Congress on Rheology 2012, Lisbon" konferencián

[7] Kőkúti Z., K. van Gruijthuijsen, Jenei M., Tóth-Molnár G., Czirják A., Kokavecz J., Szabó G., Ailer P., Palkovics L.:

Szilikonolajok nagyfrekvenciás reológiai tulajdonságai

A Jövő Jáműve: Jármüipari Innováció (1-2) pp. 38-41. (2013)

[8] A. Czirják, Z. Kőkuti, G. Tóth-Molnár, P. Ailer, L. Palkovics, G. Szabó: Simulated Rheometry of a Nonlinear Viscoelastic Fluid" COMSOL Conference 2013, Rotterdam, contributed talk 


\section{Köszönetnyilvánítás}

Köszönöm témavezetőmnek, Dr. Czirják Attilának, hogy minden szakmai és kevésbé szakmai kérdésemre megfontolt és pontos választ adott. Köszönöm, hogy közös munkánk során rendíthetetlen türelemmel próbálta meg átadni azt a tudományos szemléletmódot és szellemi eszköztárat melyre egy kutatónak feltétlen szüksége van.

Köszönöm a Müszaki és Anyagtudományi Intézet munkatársainak, mindenekelőtt Dr. Kokavecz Jánosnak, hogy a munkám során bármikor bizalommal fordulhattam hozzá szakmai kérdésekkel kapcsolatban.

Köszönöm a Szegedi Tudományegyetem Gyógyszertechnológiai Intézetének, hogy a tulajdonukban lévő reométert használhattam.

Köszönöm családom tagjainak, mindenekelőtt feleségemnek az elengedhetetlen biztatást, némelyiküknek pedig azt a többlettürelmet, mellyel a vállukra nehezedö, nem klasszikus mechanikai értelemben vett nyomást viselték, míg én a dolgozaton munkálkodtam.

Továbbá köszönöm Dr. Pálinkó Istvánnak és Dr. Gál Andornak, hogy idejüket nem sajnálva tüzetesen átnézték és hasznos megjegyzésekkel egészítették ki az értekezést. 


\section{Irodalomjegyzék}

[1] Walters K: Rheometry, Wiley (1975)

[2] Steffe JF: Rheological Methods in Food Process Engineering, Freeman Press (1996)

[3] Aris R: Vectors, Tensors, and the Basic Equations of Fluid Mechanics, Dover Publications (1962)

[4] Newton IS, Principa Mathematica (1687)

[6] Freeman SM, Weissenberg K, Conf. British Rheologist's Club, 36 (1946)

[7] Barnes HA: A handbook of elementary rheology, The University of Wales (2000)

[8] Tanner RI: Engineering Rheology, Oxford Engineering Science Series (2000)

[9] Boger DV, Walters K: Rheological Phenomena in Focus, Rheology Series (1993)

[10] Bird RB, Armstrong RC, Hassager O: Dynamics of Polymeric Liquids, [Volume 1: Fluid Mechanics], 1st Edition, Wiley (1987)

[11] Wilchinsky Z: Theoretical Treatment of Hooke's Law, Am. J. Phys., 7 (1939) 134.

[12] Boyce WE, DiPrima RC: Elementary Differential Equations and Boundary Value Problems, 3rd Edition, Wiley (1977)

[13] Larson RG, Constitutive Equations for Polymer Melts and Solutions, Butterworth, (1988)

[14] Ferry JD: Viscoelastic Properties of Polymers, Wiley (1980)

[15] Morrison FA, Understanding Rheology, Oxford University Press (2001)

[16] Cox WP, Merz EH: Correlation of dynamic and steady flow viscosities, J. Polym. Sci., 28 (1958) 619-622.

[17] Truesdell C, Noll W: The Nonlinear Field Theories of Mechanics, Springer (1965)

[18] White JL, Metzner AB: Development of constitutive equations for polymeric melt and solutions, J. Appl. Polym. Sci., 7 (1963) 1867-1889.

[19] Willenbacher N, Oelschlaeger C: Dynamics and structure of complex fluids from high frequency mechanical and optical rheometry, Current Opinion in Colloid \& Interface Science, 12 (2007) 43-49. 
[20] Crassous JJ, Régisser R, Ballauff M, Willenbacher N: Characterization of the viscoelastic behavior of complex fluids using the piezoelastic axial vibrator, J. Rheol, 49 (2005) 851-863.

[21] Longin PY, Verdier C, Piau M: Dynamic shear rheology of high molecular weight polydimethylsiloxanes: comparison of rheometry and ultrasound, J. Non-Newton Fluid Mech., 76 (1998) 213-232.

[22] Squires TM, Mason TG.: Fluid Mechanics of Microrheology, Annual Review of Fluid Mechanics, 42 (2010) 413-438.

[23] Pine DJ, Weitz DA, Chaikin PM, Herbolzheimer E: Diffusing wave spectroscopy, Phys. Rev. Lett., 60 (1988) 1134-1137.

[24] Maret G: Diffusing-wave spectroscopy, Current Opinion in Colloid \& Interface Science, 2 (1997) 251-257.

[25] Mason TG, Gang H, Weitz DA: Diffusing-wave-spectroscopy measurements of viscoelasticity of complex fluids, J. Opt. Soc. Am. A, 14 (1997) 139-149.

[26] Mason TG: Estimating the viscoelastic moduli of complex fluids using the generalized Stokes-Einstein equation, Rheol. Acta, 39 (2000) 371-389.

[27] Giacomin AJ, Dealy JM: Large-amplitude oscillatory shear, In: Collyer AA (ed.) Techniques in rheological measurements, Ch 4. Elsevier (1993)

[28] Pipkin AC: Lectures on viscoelasticity theory, Springer (1972)

[29] Ewoldt RH, Clasen C, Hosoi AE, McKinley GH: Rheological fingerprinting of gastropod pedal mucus and synthetic complex fluids for biomimicking adhesive locomotion, Soft Matter, 3(5) (2007a) 634-643.

[30] Hyun K, Nam JG, Wilhelm M, Ahn KH, Lee SJ: Large amplitude oscillatory shear behaviour of PEO-PPO-PEO triblock copolymer solutions, Rheol. Acta, 45(3) (2006) 239-249.

[31] Philippoff W: Vibrational measurements with large amplitudes, Trans. Soc. Rheol., 10(1) (1966) 317-334.

[32] Sim HG, Ahn KH, Lee SJ: Large amplitude oscillatory shear behaviour of complex fluids investigated by a network model: a guideline for classification, J. Non-Newton Fluid Mech., 112(2-3) (2003) 237-250. 
[33] Tee TT, Dealy JM: Nonlinear viscoelasticity of polymer melts, Trans. Soc. Rheol., 19(4) (1975) 595-615

[34] Vananroye A, - Leen P, Puyvelde PV, Clasen C: TTS in LAOS: validation of timetemperature superposition under large amplitude oscillatory shear, Rheol. Acta, 50 (2011) 795-807

[35] Wilhelm M: Fourier-transform rheology, Macromol. Mater. Eng., 287 (2002) 83-105.

[36] Dealy JM, Wissbrun KF: Melt Rheology and Its Role in Plastics Processing: Theory and Applications, Van Nostrand Reinhold (1990).

[37] Bird RB, Armstrong RC, Hassager O: Dynamics of Polymeric Liquids, [Volume 1: Fluid Mechanics], Wiley (1987)

[38] Hyun K, Wilhem M, Klein CO, Cho KS, Nam JG, Ahn KH, Lee SJ, Ewoldt RH, McKinley GH: A review of nonlinear oscillatory shear tests: Analysis and application of large amplitude oscillatory shear (LAOS), Progress in Pol. Sci., 36 (2011) 16971753.

[39] Carotenuto C, Grosso M, Maffettone PL: Fourier Transform Rheology of Dilute Immiscible Polymer Blends: A Novel Procedure To Probe Blend Morphology, Macromolecules, 41 (2008) 4492-4500.

[40] Klein CO, Spiess HW, Calin A, Balan C, Wilhelm M: Separation of the Nonlinear Oscillatory Response into a Superposition of Linear, Strain Hardening, Strain Softening, and Wall Slip Response, Macromolecules, 40(12) (2007) 4250-4259.

[41] Neidhöfer T, Sioula S, Hadjichristidis N, Wilhelm M: Distinguish linear from starbranched polystyrene solutions with Fourier-Transform Rheology, Macromol. Rapid Commun., 25 (2004) 1921.

[42] Fleury G, Schlatter G, Muller R: Non Linear Rheology for Long Chain Branching characterization, comparison of two methodologies : Fourier Transform Rheology and Relaxation, Rheol. Acta, 44(2) (2004) 174-187.

[43] Schlatter G, Fleury G, Muller R: Fourier Transform Rheology of Branched Polyethylene: Experiments and Models for Assessing the Macromolecular Architecture, Macromolecules, 38(15) (2005) 6492-6503. 
[44] Vittorias I, Parkinson M, Klimke K, Debbaut B, Wilhelm M: Detection and quantification of industrial polyethylene branching topologies via Fourier-transform rheology, NMR and simulation using the Pom-pom model, Rheol. Acta, 46(3) (2007) 321-340.

[45] Hyun K, Ahn KH, Lee SJ, Sugimoto M, Koyama K: Degree of branching of polypropylene measured from Fourier-transform rheology, Rheol. Acta, 46(1) (2006) 123-129.

[46] Hyun K, Baik ES, Ahn KH, Lee SJ, Sugimoto M, Koyama K: Fourier-transform rheology under medium amplitude oscillatory shear for linear and branched polymer melts, J. Rheol., 51 (2007) 1319-1342.

[47] Cho KS, Hyun K, Ahn KH, Lee SJ: A geometrical interpretation of large amplitude oscillatory shear response, J. Rheol 49(3) (2005) 747-758.

[48] Ewoldt RH, Hosoi AE, McKinley GH: New measures for characterizing nonlinear viscoelasticity in large amplitude oscillatory shear, J. Rheol, 52(6) (2008) 1427-1458.

[49] Blazek J: Computational Fluid Dynamics: Principles and Applications, Elsevier (2001)

[50] Mark JE, Allcock HR, West R: Inorganic Polymers, Prentice Hall: Engelwood Cliffs (1992)

[51] Jerschow P: Silicone Elastomers, Smithers Rapra Technology (2002)

[52] Ghannam MT, Esmail MN: Rheological Properties of Poly(dimethylsiloxane), Ind. Eng. Chem. Res., 37 (1998) 1335-1340.

[53] Hadjistamov D: Viscoelastic Properties of Filled Silicone Fluids, Appl. Rheol., 3 (1993) 113.

[54] Pavlinek V, Saha P, Kitano T, Tanegashima T: Influence of the Electric Field on the Electrorheological Behaviour of Cellulose Suspensions in Silicone Oils, Appl. Rheol., 9 (1999) 64.

[55] Mall-Gleissle SE, Gleissle W, McKinley GH, Buggisch H: The normal stress behaviour of suspensions with viscoelastic matrix fluids, Rheol. Acta, 41 (2002) 6176. 
[56] Hadjistamov D: Viscoelastic Behavior of Disperse Systems with Silicone Oil and Different Fillers, Appl. Rheol., 12 (2002) 297.

[57] Ziegelbaur RS, Caruthers JM: Rheological properties of poly(dimethylsiloxane) filled with fumed silica: I. Hysteresis behaviour, J. Non-Newton Fluid Mech., 17 (1985) 4568.

[58] Velankar S, Van Puyvelde P, Mewis J, Moldenaers P: Steady-shear rheological properties of model compatibilized blends, J. Rheol., 48 (2004) 725.

[59] Ndong RS, Russel WB: Rheology of surface-modified titania nanoparticles dispersed in PDMS melts: The significance of the power law, J. Rheol., 56 (2012) 27.

[60] Rolón-Garrido VH, Wagner MH: The damping function in rheology, Rheol. Acta, 48 (2009) 245-284.

[61] Raimbault V, Rebière D, Dejous C, Guirardel M, Pistré J, Lachaud JL: High frequency microrheological measurements of PDMS fluids using saw microfluidic system, Sensors and Actuators B, 144 (2010) 467-471.

[62] Brandstaetter M: MCR Series: Correct Adjustment of the Rheometer and Measurement of Standard Samples using RheoPlus, Anton Paar Application Report C92IA005EN-A (2013).

[63] Kataoka T, Ueda S: Viscosity-Molecular Weight Relationship for Polydimethylsiloxane, Polymer Letters, 4 (1966) 317-322.

[64] Kissi NE, Piau JM, Attané P, Turrel G: Shear rheometry of polydimethylsiloxanes. Master curves and testing of Gleissle and Yamamoto relations, Rheol. Acta 32 (1993) 293-310.

[65] Hadjistamov D: Dependance of the First Normal Stress Difference of Silicone Oils on Zero-Shear Viscosity and Molecular Weight, Appl. Rheol. 6 (1996) 203.

[66] Hadjistamov D: Determination of the Onset of Shear Thinning of Polydimethylsiloxane, J. Applied Polymer Sci., 108, (2008) 2356-2364.

[67] Fan Y, Liao H: Experimental Studies on the Relaxation Behavior of Commercial Polymer Melts, J. Applied Polymer Sci., 110, (2008) 1520-1530. 
[68] Longin PY, Verdier C, Piau M: Dynamic shear rheology of high molecular weight polydimethylsiloxanes: comparison of rheometry and ultrasound, J. Non-Newton Fluid Mech., 76 (1998) 213-232.

[69] http://www.anton-paar.hu/Prospektusok/APH_MCR-HUN-Erv2009.pdf

[70] Barnes HA, Hutton JF, Walters K: An introduction to rheology, Elsevier (1989)

[71] Mooney M, Ewart RH: Physics, 5 (1934) 350.

[72] Bagley EB: End corrections in the capillary flow of polyethylene, Journal of Applied Physics, 28 (1957) 93-209.

[73] Hanselman D, Littlefield B: Mastering Matlab 7, Prentice Hall: UpperSaddle River (2005)

[74] Nelder JA, Mead R: A simplex method for function minimization, Computer Journal 7 (1965) 308-313.

[75] Mezger TG: The Rheology Handbook, Vincentz (2011)

[76] Wacker Siliconöle AK, Wacker-Chemie GmbH, München (2001)

[77] Zakharov P, Cardinaux F, Scheffold F: Multispeckle diffusing-wave spectroscopy with a single-mode detection scheme, Phys. Rev. E, 73 (2006) 011413. 